Florida International University FIU Digital Commons

7-14-1992

\title{
Relevance of the community college curriculum to the international student
}

Michael Baglino
Florida International University

DOI: $10.25148 /$ etd.FI14050405

Follow this and additional works at: https://digitalcommons.fiu.edu/etd

Part of the Higher Education Commons

\section{Recommended Citation}

Baglino, Michael, "Relevance of the community college curriculum to the international student" (1992). FIU Electronic Theses and Dissertations. 1368.

https://digitalcommons.fiu.edu/etd/1368

This work is brought to you for free and open access by the University Graduate School at FIU Digital Commons. It has been accepted for inclusion in FIU Electronic Theses and Dissertations by an authorized administrator of FIU Digital Commons. For more information, please contact dcc@fiu.edu. 


\section{ABSTRACT OF THE DISSERTATION}

Relevance of the Community College Curriculum

to the International Student

by

Michael Baglino

Florida International University, 1992 Miami, Florida

Dr. Joseph B. Cook, Major Professor

The purpose of this study was to ascertain the perception of the level of satisfaction that international students have regarding the services and the relevance of the curriculum offered at MiamiDade Community College. Trends and issues at universities and community colleges in providing services and an international curriculum for foreign students are outlined. Focus is on characteristics, personal and career needs as well as needs of national development for the students' countries.

A sample of students from four developing nations was selected to qualitatively and quantitatively determine their level of satisfaction. The nations are the Bahamas, Colombia, Haiti and 
Pakistan. Students responses were recorded through group interviews, four personal interviews, an open ended questionnaire and a Likert scaled survey questionnaire. Matrix charts, mean calculations and one way analysis of variance were used to analyze data collected. Country of origin and major program of study were the variables used for statistical analysis.

Information gathered through qualitative research presented a variety of perspectives and responses, both positive and negative. Students supplied specific examples of experiences and insights to help explain their various perceptions. Statistically, there were no significant differences between the variables of country of origin and major program of study regarding program services and relevance of the curriculum. Implications and recommendations for community college programs were outlined. 


\title{
FLORIDA INTERNATIONAL UNIVERSITY \\ Miami, Florida
}

\author{
Relevance of the Community College Curriculum \\ to the International Student
}

\begin{abstract}
A dissertation submitted in partial satisfaction of the requirements for the degree of Doctor of Education in Community College Teaching
\end{abstract}

by

Michael Baglino 
To Professors:
Dr. Joseph Cook
Dr. Carlos M. Alvarez
Dr. Hugh Gladwin

This dissertation, having been approved in respect to form and mechanical execution, is referred to you for judgment upon its substantial merit.

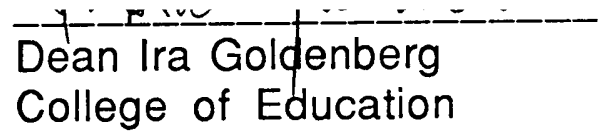

The Dissertation of Michael Baglino is approved.

Dr. Joseph Cook, Major Professor Dr. Carlos M. Alvarez

Date of Examination:

July 14,1992
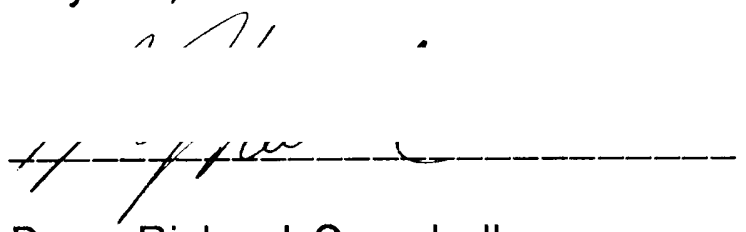

Dean Richard Campbell

Division of Graduate Studies 


\section{DEDICATION}

I would like to extend thanks and appreciation to all those who contributed to the success of this dissertation. Each individual contributed significantly every step of the way.

Mr. Norman Ponce, friend and colleague at Dade County Public Schools, was instrumental in my mastery of necessary computer skills. The direction and form of the dissertation was initially influenced by Dr. Joel Fleisher and Dr. Marcia Belcher of Miami-Dade Community College. Dr. Lorraine Gay and Dr. Paulette Johnson of Florida International University were helpful with methodology and analysis. Appreciation and gratitude is given to committee members Dr. Joseph Cook, Dr. Hugh Gladwin and Dr. Carlos Alvarez for their guidance and time throughout the course of the study.

I wish to especially acknowledge the contribution of the faculty and community of Winona State University in Winona, Minnesota. The academic preparation, training and belief in my abilities is the foundation that made this endeavor possible. Their friendship and Christian service, so characteristic of this university and community, has been the model and standard to which I will always aspire.

Finally, special thanks is given to my wife Sarah. There could not have been a successful completion of this dissertation without her love, patience and support. 


\section{VITA}

Michael Baglino was born March 9, 1944 in Brooklyn, New York. After moving to Long Island and graduating from W. T. Clarke High School in East Meadow School District, he attended Winona State College (now university) in Minnesota. There he received a B. A. (1966) and M. S. (1968) in Secondary Social Science, and a 6th Year Professional Certificate (1974) in Educational Administration and Supervision.

He worked in the public schools of Minneapolis, New York and Miami as well as Catholic Schools in South Florida. The major portion of his career was in Adult and Community College Education as teacher and supervisor in E.S.L., A.B.E. and Social Sciences. His interest in International education was a result of experiences in the multicultural school environments of these three urban areas and the opportunity to temporarily reside in Spain and Italy.

He began graduate studies at Florida International University in September, 1981 which culminated with an Ed. D. in June, 1992. His major was Community College Teaching in Behavioral Sciences with emphasis in international and adult education and a cognate in Political Science. 


\section{TABLE OF CONTENTS}

Page
ABSTRACT
DISSERTATION COMMITTEE APPROVAL
ii
DEDICATION
VITA iv
LIST OF TABLES
ix
LIST OF FIGURES
xiv
Chapter 1
STATEMENT OF THE PROBLEM
INTRODUCTION
THE PROBLEM
THE RESEARCH QUESTION
DEFINITION OF TERMS
ASSUMPTIONS OF THE STUDY

Chapter II

REVIEW OF THE RELATED LITERATURE

GENERAL CHARACTERISTICS OF FOREIGN STUDENTS 9

NEEDS OF INTERNATIONAL STUDENTS 
Page

CURRICULUM RELEVANCE

INSTITUTIONAL APPROACH TOWARD CURRICULUM RELEVANCE

ISSUES

22

INTERNATIONAL EDUCATION AND THE COMMUNITY COLLEGE

SUMMARY

Chapter III

THE RESEARCH DESIGN

STATISTICAL HYPOTHESES

RATIONALE

SETTING

POPULATION AND SAMPLE

PROCEDURES

QUALITATIVE AND QUANTITAVE ANALYSIS OF DATA 
QUALITATIVE DATA

GROUP INTERVIEW AND OPEN DISCUSSION GUIDELINES

PERSONAL INTERVIEWS

MATRIX CHARTS

QUANTITATIVE DATE

PERCEIVED LEVEL OF SATISFACTION OF COLLEGE SERVICES ACCORDING TO COUNTRY AND MAJOR

PERCEIVED LEVEL OF SATISFACTION OF THE RELEVANCE OF THE COMMUNITY COLLEGE CURRICULUM ACCORDING TO COUNRY AND MAJOR

TESTS OF HYPOTHESES

SUMMARY, FINDINGS, CONCLUSION AND

RECOMMENDATIONS

SUMMARY

FINDINGS

CONCLUSIONS

IMPLICATIONS

LIMITATIONS OF THE STUDY

SUGGESTIONS FOR FUTURE RESEARCH 
A. FIGURES 1 AND 2

B. NATIONAL DESCRIPTION

C. ISSUES OF CURRICULUM RELEVANCE TABLES 4 TO 6

D. DESCRIPTION OF COMMUNITY COLLEGES

TABLES A, B, C, D, FIGURE 3

E. LETTERS AND QUESTIONNAIRES

F. SUMMARY OF RESULTS

TABLES 33-36

G. RELIABILITY SCORES

TABLE E 


\section{LIST OF TABLES}

Table

1. Opening Fall Enrollments: 1976

2. Opening Fall Enrollments: 1982

3. Problems and Sources of Difficulties: Rank by Country of the Five Most Troublesome Areas

4. Needs Related to Relevance of the U. S. Degree, Needs for Extracurriculuar Professional Activities in U. S.

5. Percentage of Students in Each Country Group Who

Considered the Event Might Make Them Remain in the U. S. Permanently

6. Mean Scores of Likelihood to Remain in U. S., Anticipated Satisfaction at Home, and Perceived Racial Barrier in the U. S.

7. Distribution According to Country

8. Distribution According to Age

9. Distribution According to Sex

10. Distribution According to Marital Status 52

11A, 11B. Distribution According to Major

11C. Distribution According to Majors/Grouped

12. Distribution According to Possibility of Remaining in U. S. 55

13. Distribution According to Job Availability at Home

14. Distribution According to Expected Degree 
15A. College Offer of Adequate Services to Aid in Adjustment to Life in U. S. by Country

15B. College Offer of Adequate Services to Aid in Adjustment to Life in U. S. by Major

16A. Community And Health Services Available to Foreign Students and Families by Country

16B. Community And Health Services Available to Foreign Students and Families by Major

17A. The Opportunity to Assess Academic and Personal Career Needs with Counselors and Advisors by Country

17B. The Opportunity to Assess Academic and Personal Career Needs with Counselors and Advisors by Major

17C. One Way Analysis of Variance: The Opportunity to Assess Academic and Personal Career Needs with Counselors and Advisors by Country

18A. Availability of Information and Procedures in Planning the College Program by Country

18B. Availability of Information and Procedures in Planning the College Program by Major

18C. One Way Analysis of Variance: Availability of Information and Procedures in Planning the College Program by Country

19A. Faculty Members Spending Time for Association or Guidance by Country

19B. Faculty Members Spending Time for Association or Guidance by Major 
20A. Receiving Credit for Academic Work Done Outside the U. S. by Country

20B. Receiving Credit for Academic Work Done Outside the U. S. by Major

21A. College Curriculum Relevant to Your Future Job in Your Country by Country

21B. College Curriculum Relevant to Your Future Job in Your Country by Major

22A. Opportunites to Give Information About Your Country in Classes by Country

22B. Opportunites to Give Information About Your Country in Classes by Major

23A. Curriculum That Included International Materials in Courses by Country

23B. Curriculum That Included International Materials in Courses by Major

24A. Availability of Seminars Dealing With Problems of National Development by Country

24B. Availability of Seminars Dealing With Problems of National Development by Major

25A. College Curriculum Relevant to Needs of Your Country by Country

25B. College Curriculum Relevant to Needs of Your Country by Major

26A. Level of Technology Applicable to the Future of Your Country by Country 
Table

26B. Level of Technology Applicable to the Future of Your Country by Major

27A. Curriculum Including Training to Introduce Changes in Your Country by Country

27B. Curriculum Including Training to Introduce Changes in Your Country by Major

28A. Curriculum Including Training for a Leadership Role in Your Country by Country

28B. Curriculum Including Training for a Leadership Role in Your Country by Major

29A. The Exchange of Visiting Professors Between Universities of Your Country and This College by Country

29B. The Exchange of Visiting Professors Between Universities of Your Country and This College by Major

29C. One Way Analysis of Variance: The Exchange of Visiting Professors Between Universities of Your Country and This College by Country

30A. Opportunity for Practical Experience in Your Field Before Returning Home by Country

30B. Opportunity for Practical Experience in Your Field Before Returning Home by Major

31A. Mean of the Series of Questions Related to Satisfaction of College Services by Country

31B. Mean of the Series of Questions Related to Satisfaction of College Services by Major

31C. Mean of the Series of Questions Related to Satisfaction of Curriculum Relevance by Country 
Table

31D. Mean of the Series of Questions Related to Satisfaction of Curriculum Relevance by Major

32A. One Way Analysis of Variance for Series of Questions Related to Satisfaction of College Services by Country

32B. One Way Analysis of Variance for Series of Questions Related to Satisfaction of College Services by Major

32C. One Way Analysis of Variance for Series of Questions Related to Satisfaction of Curriculum Relevance by Country

32D. One Way Analysis of Variance for Series of Questions Related to Satisfaction of Curriculum Relevance by Major

33. Summary of Results: Means of the Perception of Satisfaction of College Services to the International Student by Country

34. Summary of Results: Means of the Perception of Satisfaction of College Services to the International Student by Major

35A, 35B. Summary of Results: Means of the Perception of Satisfaction of Relevance of the College Curriculum to the International Student by Country

36A, 36B. Summary of Results: Means of the Perception of Satisfaction of Relevance of the College Curriculum to the International Student by Major

A. International Student Enrollment by World Region: National Comparisons With Miami-Dade Community College

B. Community Colleges with the Most International Students 
C. Top Ten Program Declarations of Visa Students at

D. Ethnic Headcount by Campus: Miami-Dade Community College, Fall, 1991

E. Reliability Scores

\section{LIST OF FIGURES}

Figure

Page

1. Foreign Students: 1980 and 1990

2. Foreign Students in $1990 / 407,530$

3. Educational Objectives of Students by Citizenship: Miami-Dade Community College 
Chapter I

\title{
STATEMENT OF THE PROBLEM
}

\author{
INTRODUCTION
}

Modernization refers to technology inducing economic growth and transforming institutions. Consciousness results when that social reality confronts individuals. This worldwide experience also includes the imposition of modernized institutions upon the third world (Berger, 1973: 12-20). An important aspect of this modernization process is the movement of students across cultures for advanced vocational and career training abroad. This involves transfer of knowledge and skills from educational institutions to students of the developing third world. Many of these third world students attend higher educational institutions of the United States for such training. Consequently foreign students must adapt culturally to a new environment. In that process of educational and vocational training, there is an invaluable contribution by the foreign student to his home country and also the host country.

The Higher Education General Information Survey (Solmon, 1987: xii) reports that the number of foreign students enrolled in $U$. S. colleges and universities in the 1980's was approaching 400,000. This is $2.6 \%$ of the student population. More recently, the 
Institution of International Education Open Doors study (Zikopoulos, 1991: 1-22) reported a yearly rise of $5.3 \%$ from 386,900 foreign students attending U. S. colleges and universities in 1990 to a record total of 407,500 . As the United States and third world nations continue to interrelate in this modernization process, it becomes important to the national interest in educating foreign students. This cross cultural phenomena has important implications for policy both nationally and the college community. In this regard, Seth Spaulding and George Coelho (1980) as part of a work on copng with the dilemmas of uprooting, development and modernization, have made several policy recommendations. They include continued communication with former foreign students, recruiting, counseling and advising. They also recommend U. S. legislative and university support for international organization necessary for the effective transfer of training and technology. Such policies would then relate to institutional missions, including all segments of the college community.

The increasing number and variety of foreign students trained in the United States now participate in an atmosphere of a developed country. This is quite a different cultural, ideological and academic milieu. Also they arrive with a belief in the relationship between education and social and economic development. They intend to relate the results of their education to both their personal goals and country's needs. Thus they are concerned with both adjusting to the environment of a developed country and the relevance of their education in meeting personal and national needs. 


\section{THE PROBLEM}

In view of this modernization phenomena for the third world, the impact of a growing number of foreign students at American colleges places program obligations upon these institutions (Emerson, 1979: 87-93). In practical remedies this would mean a more international college curriculum. An international curriculum encourages intercultural competencies and knowledge for professors, affects technology transfer and provides additional services for foreign students in this adaptation process. Moreover, the influx of foreign students has created a demand upon American higher education to meet academic needs of these students relevant to the needs of their less developed home country. Curriculum relevance toward national development has meant creating ways of becoming aware of the students' country's needs, solutions to national problems and involvement with international agencies such as AID and the World Bank (Taylor, 1979: 188-190). It also means imparting technical skills, leadership and job training and English language instruction.

Thus, the foreign student demand toward a curriculum relevant to their own career and national development aspirations suggests that colleges and universities move forward in designing curriculum to meet such needs. Therefore this study intends to outline the trends in institutions of higher education, especially the community college, in providing program services and a curriculum 
relevant for foreign students. More specifically, it shall qualitatively and quantitatively determine the level of satisfaction foreign students perceive the community college has met their personal and career needs.

\section{THE RESEARCH QUESTION}

The purpose of this study is to determine perceptions held by community college students regarding the satisfaction of selected personal and curricular needs. It will analyze variables which may influence the perceptions held by community college students. I will answer the following questions through this study.

1. What is the level of satisfaction foreign students have regarding program services offered by the community college?

2. How satisfied are foreign students with the relevance of the community college curriculum?

3. Which specific aspects of the international education curriculum do foreign students perceive as relevant?

4. Is there a relation between the foreign student country of origin and level of satisfaction with program services and curriculum relevance?

5. Do students' perceptions of satisfaction with program services and curriculum relevance relate to the major area of academic or vocational training? 


\section{DEFINITION OF TERMS}

\section{Advisor}

Staff member who is delegated the responsibility of admitting, registering, academic advising and informing foreign students of personal services offered at the community college.

\section{Community College}

An institution in American higher education offering education and training equivalent to up to two years at a college or university.

\section{Consortium}

A voluntary association of two or more colleges providing joint services and academic programs in international education for students enrolled in member institutions.

\section{Currriculum}

The total intended learning experiences available for students at a community college or university.

Developing Nation

An underdeveloped nation in the process of development. 


\section{Development}

Conditions which help bring about modernization, economic growth and improvement of social conditions within a nation.

\section{Foreign Student}

An international student holding an F-1 visa; a student in the $U$. S. who is originally from another country, neither a citizen nor immigrant, temporarily in the U.S. for the express purpose of attending an educational institution and intending to return to the home country.

\section{International Education}

The broad field of interests, services and educational programs involving instruction and curriculum designed to promote knowledge and understanding of intercultural and international differences, similarities and interdependence. It includes global education, foreign language study, study abroad, foreign student exchanges and comparative studies.

\section{International Student}

A foreign student. 


\section{Perception}

Awareness and consciousness by foreign students that the education and training received was satisfactory or unsatisfactory in meeting their personal, academic and career needs.

Relevance

Education and training that is considered useful and applicable to the needs, problems and future role of the foreign student in his home country.

\section{Satisfaction}

That the personal, academic and career needs of foreign students were both supplied and gratified.

\section{Technical Assistance}

The training and transfer of knowledge and technology from the United States to a developing nation.

\section{ASSUMPTIONS OF THE STUDY}

This study is limited to full time foreign students with $F 1$ Visa at Miami-Dade Community College. The focus is on the personal and academic needs of foreign students as they pursue and American education. Most students are from developing countries which have 
certain socio-economic needs in their efforts toward development. The relevance of the students' education to their future role in their country is the major issue. Therefore, the following are assumptions with regard to the above:

1. that the sample of students from each country reflects the entire foreign student population of that country at the college;

2. that foreign students are aware of the socio-economic needs of their country;

3. that they will return to their country to contribute to their country's development;

4. that they represent future leaders and change agents in their countries;

5. that there will be some problems applying the skills learned in the U.S. to their home country;

6. that relevance in education is best realized after applying the skills learned in the U.S. to the home country situation. 
Chapter II

REVIEW OF THE RELATED LITERATURE

\section{GENERAL CHARACTERISTICS OF FOREIGN STUDENTS}

The economic and social changes occuring in nations of the third world is of particular interest to the United States. Now a large number of academically competent students with leadership potential have the opportunity of undergraduate study in American colleges and universities. Upon completion of their education they can then enter roles significant to development in their home countries. The general characteristics of the current international student population help clarify the purposes and perspectives of international students in this effort. Solmon and Young (1987) have collected information on enrollment characteristics of international students from two major sources: the Higher Education General Information Survey (HEGIS) and the Cooperative Institutional Research Program (CIRP). Another major source is the periodic report of the Institute of International Education which gives statistics on major trends, and academic and personal characteristics. These sources also summarize findings on foreign student countries of origin and their regional distribution in the $U$. S. 
The Institution of International Education Open Doors study reported a yearly rise of $5.3 \%$ from 386,900 foreign students attending U. S. colleges and universities in 1990 to a record total of 407,500. More than half of that number were Asians, whose population increased by $10.4 \%$. The increase of Asians as well as Europeans, Latin Americans and Canadians offset the decrease in the number of students from Africa, the Middle East and Oceania. (Figures 1,2) The number from Eastern Europe and the Soviet Union grew to 4,800 , a $42 \%$ increase. The majority of students came from East Asian countries while Latin America ranked as the second largest contributor. China, Taiwan, Japan, India, Malaysia, Korea and Hong Kong rank as the top seven of eight countries listed. The People's Republic of China, the leading country, sent 39,600 and Japan was a close second with 36,610. Taiwan however, was a close third with 33,500 , representing a $8.3 \%$ gain. (Zikopoulos, 1991: 1-22)

The survey also reported that most foreign students, $66 \%$, were male and nearly $90 \%$ were full time students. Community colleges enrolled $13 \%$ and four year colleges $87 \%$, with $65 \%$ at public colleges. In addition most of the foreign student population, $63 \%$, had financial support from family or personal funds. This is corroborated by the Cooperative Institutional Research Program (CIRP) study (Solmon, 1987: 1) that there were a higher proportion of males and older foreign students who came from relatively affluent and well-educated families. 
The largest proportion of foreign students attended schools in the West-Southwest region headed by California. There was a sharp increase in the Southeast, especially Florida. Though Florida ranked 5 th in the total number of foreign students, Miami-Dade Community College led in enrollment totals of all American colleges and universities with an enrollment of over 5,757 from 125 countries (Zikopoulos, 1991: 46). A disparate area between foreign and domestic students is numbers found in two year programs. In 1982, $18.5 \%$ of foreign students attended two year colleges compared to $38.8 \%$ of the domestic American college population (Tables 1 and 2) (Solmon, 1987: 43-45). This is because two year schools are less known abroad and the associates degrees offered are not as attractive to foreign students or sponsoring agencies. There are probably local training programs equivalent to the programs of community and two year colleges although community colleges are making inroads in curricular and technical assistance. Only in Florida was there a close proportional distribution of foreign students between community colleges (43\%), and universities $(57 \%)$.

Academic characteristics are similar to domestic student norms. There is a common interest in business, engineering and computer sciences. Engineering has been the leading field of study throughout the 1980's and remains so in 1991. In addition more foreign students are preparing for a world of international business and telecommunications with the increased interest in mathematics/computer science and business management. The 
most significant academic trend noted was the increase in students moving beyond the undergraduate level into graduate school.

\section{NEEDS OF INTERNATIONAL STUDENTS}

In general students at foreign universities have reported material and personal services for coping as satisfactory. Much of this has depended on a student's previous travel and his/her satisfaction with the studies provided. Klineberg and Hull (1979) report that the gravest problems deal with housing, social contact and discrimination. Few actually desire to remain in the host nation and most prefer to return home. In the U.S. however, students maintain that their problems center around finances, social adjustment and academic difficulties (Omar, 1986). The need to socialize, adjust to differing concepts of time, structure and independence, and written approach to assignments as opposed to verbal approach, concern most foreign students in the U.S.

The focus of Klineberg and Hull's study was on personal and academic needs dealing with coping at a foreign university. This was a study of foreign student behaviors from students in 11 nations: Brazil, Canada, France, Hong Kong, India, Iran, Japan, Kenya, U. K. , West Germany and U. S. Of these eleven, seven are developing nations and represent three continents. Some specific problems and sources of difficulty included ill health, personal depression, adjustment to climate and food, social contact, sex and religion, 
and finances. On an academic level, needs surveyed included difficulties with language, administration, courses, study and progress of studies, advisement and counseling. In all, foreign students studying in these countries reported high levels of satisfaction in meeting needs, especially academic needs more than personal. (Table 3)

In a U. S. national survey of 2000 foreign students from developing nations, Lee (1981) sought out foreign student perceptions of importance and levels of satisfaction in meeting personal and academic needs. Lee itemized student adjustment problems but also focused upon the relevance of their American education. She classified needs into needs for information, the degree program and program relevance. Needs for information revolved around information on American culture, community, health and housing services. They were also concerned with information on procedures and regulations for immigration, registration and course requirements. Needs related to the degree program concerned the roles of advisors and professors. Were advisors and faculty available for planning and consultation? Was there contact with faculty having international experience? Needs related to relevance of the $\mathrm{U}$. S. degree program concerned the students' future jobs. Were they being prepared to assume a role as leader and change agent? Did the program address needs of the home country? Could they apply the learned technology? Finally, were there opportunities of dealing with problems of development through seminar and faculty exchanges? (Table 4) 
In a study of incoming international students at the University of Maryland, Boyer and Sedlacek (1987) surveyed attitudes and perceptions concerning personal and academic needs. Students responded to questions under the categories of attitudes and expectations toward counselors, study habits and academic background, educational expectations, vocational goals and personal orientation. Results showed that international students take their education quite seriously. They are most concerned with financial matters, but did expect to complete graduation requirements. Many previous studies have shown that international students have strong academic skills with high aspirations and positive attitudes but have had many adjustment difficulties. The major difficulties include learning English, adjusting to a new culture and meeting financial expenses. Despite problems they are reluctant to initiate counseling relationships. For example, in contrast to American students who show a willingness to take responsibility in the counseling process, Asian and African students expect counselors to be authoritarian and give clear cut solutions to problems as they remain passive and dependent. Most intend to pursue graduate work and feel no obstacles preventing them from obtaining their vocational goals. They had a personal orientation toward sports and a belief that job experience and independent study contributed most to their development. In relation to counseling and advisement, international students have a broad range of concerns. They deal with educational and vocational, emotional and social and academic issues. They seek experienced, sensitive and "real" counselors who 
can share feelings and make them comfortable.

The professional role and responsibilities of foreign student advising further calls attention to the specified personal and academic needs of international students (NAFSA, 1988). In working with international students, foreign student advisors provide information on programs and services offered at the college or university. This may include immigration rules and regulations, housing and health services, advisement on financial and visa problems, and conduct orientation and intercultural programs. As a liason and representative for students, advisors promote relationships between foreign students and other students, faculty and staff. They also represent or advocate for foreign students in dealing with government agencies, school departments and community members. They thus become another vehicle for the enhancement of international education on campus.

Universities and colleges have tried to consider several approaches to meet the many social, psychological and adjustment needs of students. One approach has been pre-orientation programs for students as to language acquisition, school and community life and $U$. S. life in general. Another is establishing social networks of countrymen and recognizable student organizations of foreign students (Melies, 1982: 442). Higher education institutions have also recognized the need for personal and academic counseling and staff development in intercultural understanding of the locally enrolled foreign contingent. Foreign student acceptance by staff, students and the community improves both adjustment and 
relations. Counseling and academic advisement along with assistantships and scholarships are also helpful toward improving more satisfying experiences (Lee, 1981: 131). This particular study recognizes the need and importance for both academic advisement and relevant education and training in applying knowledge in their home countries (Table 4)

\section{DIMENSIONS OF INTERNATIONAL EDUCATION}

The increasing enrollment of foreign students in the United States serves as a resource for the international education curriculum. It calls attention to the basic forces effecting the world and the U. S., especially as it concerns national development. The imposition of economic institutions and modernization process contribute to population shifts, uprootedness and interdependence among nations. As a result, a need develops for intercultural understanding, technology transfer and utilizing education for social change and national economic growth. (Craig, 1981: 41). Most foreign students in America, in fact, originate from developing nations and purposely arrive to enhance their personal role in the economic development of their country. The composition of this student population is largely from the developing countries of the Far East, Latin America and also the Middle East (Solmon, 1987; Zikopoulos, 1991).

The overall effect has been an international curriculum reflecting this growth in international relations and the global 
economy. Foreign students themselves have helped orient American students who are about to study outside the U.S. They tutor in foreign languages, participate in cross cultural workshops and contribute to particular courses by offering various foreign perspectives to issues such as human rights, health care and gerontology to name a few (Burn, 1980: 64).

The various dimensions of the college curriculum today reflects the indirect contribution foreign students have made to international education. Further, international education and an international curriculum should endure as the foreign enrollment continues to climb. The dimensions of international education encompass a variety of activities and programs dealing with technical assistance, cultural exchanges, language and area studies, and transnational institutional relationships. Trends appear to emphasize the following parameters (Spalding, 1982):

1. Foreign Language and Area Studies: allowing for intercultural understanding and interaction, interdependence among nations and appreciation of social and political perspectives as opposed to parochical views,

2. Global Education: confronting issues such as hunger, population, energy, arms control, law of the sea, trade, business, human rights, and again interdependence among nations,

3. Multicultural Education: cultural pluralism and competencies toward international socio-economic and political relationships, 
4. Cultural Exchange: bringing more students and faculty from beyond American borders to further influence international education and consider developing nations' needs,

5. Outreach Programs: inservice education, summer institutes and conferences enhancing the international realm of the higher education institution,

6. Technical Assistance: often through consortia of colleges utilizing expertise of college departments and professionals,

7. Development Education: through World Bank loans, UNESCO and university collaborative projects to establish planning, training and curriculum development toward the national development of less developed countries (LDC's).

\section{CURRICULUM RELEVANCE}

A major premise of this dissertation is that the growth of international education in American colleges reflects the growing enrollment of foreign students. The result is better understanding of the world through global studies, cultural awareness, language studies and communication with the foreign student body. International education also serves to supply national leadership in foreign relations and relate academics to technical assistance and development.

Options in international education include those characteristics regarded positive to any set of curriculum. 
Successful curriculum programs have generally included those that are flexible, allow for individualized study, and show a relationship to both student aspirations and program objectives. Curriculum would then include: 1. core courses; 2 . courses for individuality and flexibility; 3 . skills courses; 4 . integrative experiences (Dressel, 1980: 242). Thus, if the curriculum of any college is to internationalize, it would do so within the above structural framework. Specifically, these parameters of stucture include the following (Burn, 1980):

1. Core courses: theory, perspective, comparative studies, research, measurement and analysis. This area exposes students to diverse western and non western perspectives and recognizes global interrelationships. It also means learning practices and approaches which could be transplanted from one culture to another.

2. Courses for individuality and flexibility: major concentration, interdisciplinary studies, social, political and economic issues and area studies Thus, all major issues (human rights, energy, pollution, food, population and migration) have an interdisciplinary approach contributing to perspective. Each issue is treated from the perspective of politics, sociology, economics, religion and literature, either globally or from a particular region of the world.

3. Skills courses: foreign language, intercultural communication, management, administration, planning and evaluation, vocational competencies. International education requires foreign language study for purposes of understanding 
culture, intercultural communication to further reduce misunderstanding and conflict. It enhances intercultural competencies of personal, affective and pedagogical skills (ie. the psychoculturally adaptive, non judgmental and culturally knowledgeable student) (Pusch, 1980: 92). Students acquire skills in management through study of international organizations, their respective structures and approaches to international problems. Such organizations as the World Bank, U. N., UNESCO, Agency for International Development or other national administrative organizations exemplify diverse approaches to the international arena and serve to broaden the scope of administrators and leaders in all fields.

4. Integrative experiences: study abroad, field work, internships, interagency cooperation, student exchanges. International education exposes students to experiences which will serve to broaden their horizons into other worlds and views. One method of this component is study outside the $U$. S. and linking activities and practical experiences with overseas institutions or agencies. In other words, it requires the international movement of educators and students towards research, teaching and on site practicums and internships.

This adds to curriculum relevancy for the foreign student by offering such resources to their homeland. Thus, American higher education institutions and the community college serve both American and foreign national in an international campus when infused with the dimensions of an international curriculum: 
linguistic skills, intercultural competencies, global understanding and international social, political, and economic relations (Burn, 1980: 73).

\section{THE INSTITUTIONAL APPROACH TOWARD CURRICULUM RELEVANCE}

As the above parameters serve to reinforce each other toward an international curriculum, the attempt to create relevancy requires a certain emphasis (Thompson, 1976; I. I. E., 1979). One is international faculty and student exchanges for teaching, research, study and counsel. Communication with returned trainees and follow up studies is necessary to encourage continued interaction and cultural exchange. This also means staff development in intercultural competencies. Second, as the enrollment of foreign students increases, institutions need to determine criteria for admission, establish services for financial resources, counseling, health and housing and English instruction. Thirdly, regional consortiums and contacts with governments and private enterprise may have to be further developed. Lastly, institutional approaches are necessary in relating the role of American colleges to international development and assistance. This involves training foreign students for their own national needs through work study experience. It also requires links with higher education institutions of other nations which share certain philosophical orientations. 
Each would cooperate in areas of interfaculty communication, government projects, relations with society and community and student exchanges. Such services include visitations, recruitment and placement, interinstitutional purchases of material for development, technical cooperation and computer services. Thus requirements for institutional roles in curriculum relevancy encompasses a proper combination of training, student and faculty exchange and cooperation with foreign governments and international agencies. Curriculum relevancy is then successfully realized through this international interrelationship of faculty, student and institutions.

ISSUES

Assessing needs of international students is a prime issue in determining appropriate programs and curriculum. This may mean communicating with student and home country officials and agencies from each academic department. In that effort, foreign students have a degree of responsibility to bring relevant information to American professors, thus widening teacher perspective to transmit the appropriate knowledge. They also need to know the way problems are solved and how to apply solutions to the cultural and economic pattern at home. Thus knowledge must be useful and appropriate for personal application and local problem analysis (Jenkins, 1980: 8-10). The typology of needs in determining curriculum relevance is largely based on the study of $M$. Y. Lee 
(1981). Lee's research determined levels of satisfaction by investigating needs of students from developing countries attending American colleges. The study found that most students surveyed emphasized the need for relevance, and practical application of their education would meet that need. However, practical experience was a need perceived but not met. The study then recommended that colleges incorporate practical experience and internships into degree programs for foreign students. (Table 4)

A second issue concerns colleges recruiting and admitting students interested in the program of studies which they offer? Patrick (1983), in a comparative study of admissions procedures for foreign students, suggested that the institutions' capabilities to meet foreign student needs helped determine the level of satisfaction of relevance in education. Thus, they should encourage applications from students interested in pursuing specific fields unique and appropriate to that institution. The selection of foreign students is an important aspect of relevance in education. Three separate studies (Rawls and Akpanudo, 1981; Ogunbi, 1978; Lee, 1981) concluded that students with definite career objectives prior to training experienced greater academic success. These students also showed a greater interest in contributing to their country's national development. There are not many studies to date on the relevance of university or college curriculum. This may be due to the difficulty in determining an empirical relation between educational systems and socio-economic results (Moock, 1984). Thus most of the research on curriculum relevance has been in broad 
and general terms. Ekpe (1980) attempted to find the degree of satisfaction by foreign students in their education. His study found that students from developing countries were more socially than personally motivated to attend American colleges. Unlike students from developed nations, students from developing countries were aware of pressures and responsibility for development. These students also had more severe adjustment problems which effected their perception of satisfaction. The study implied that American higher education should consider development issues of developing nations and the content of a foreign student's education. Rowland (1990: xii) in a study on the relevance of foreign students' training in publich health, concluded that relevance is a shared responsibility between students, the educational institution and home country. Students responded positively about their training in public health when they had definite career plans and supported by home country and scholarship. The conclusion of Timko (1990) was that academic program planners focus on the curricular needs of international students in graduate departments of agriculture and education.

A third issue for curriculum relevance centers around the context of a student's home country's cultural, economic and political institutions. Is the acquisition of professional competencies and leadership skills in keeping with the needs of a particular developing nation? Britenbach (1970) suggested that a students return home can determine the value and relevance of study in another country. Research in this area has shown a positive correlation between a foreign student's American education and a 
perceived contribution to their country's development. Fry (1984) indicated that study abroad had a positive and significant relationship to economic performance in Thailand and Costa Rica. Maliyamkono, Ishumi and Wells (1982) conducted a study on the impact of foreign study on development in East Africa. They concluded that East African countries benefitted from investments made in overseas education. Those trained overseas appeared better prepared both for work responsibilities and the application of knowledge and skills related to employment. However, locally trained employees seemed better prepared to meet development needs of local conditions. Thus there is relevance in education when training relates to the environment of the student's country.

Davis (1973) collected information from Turkish students returning home after study in American Universities. Most believed that their training in America increased their ability to contribute to national development. Similarly, Meyer (1979: 7-17) reported that most students felt their U. S. education was useful and most students reported involvement in development efforts. Their training and vocational technical assistance were mid level skills commensurate with national needs. Such mid level skills are mostly in the areas of engineering, agriculture, data analysis, tourism and business management which are those most appropriate to their national development. In the Rawls and Akpanudo study (1981), Nigerian students who had studied in the U. S. felt their education enhanced their opportunity to contribute to national development. Particularly useful were skills in independent 
research, administration and specific field knowledge. Many who received on the job training responded satisfactorily to the relevance of their education to the Nigerian situation. The study recommended more effective educational and career counseling as well as matching educational programs to students' home countries' development needs.

Relevance then concerns not only content of skills and knowledge in the curriculum but also the utilization of that content. American higher education can provide training of relevant skills and knowledge, but utilizing that training depends on factors found in the home country: economic, social and political. Walton (1967:

11) reported that circumstances sometimes prevent the utiliztion of skills. This forces students to evaluate their training as a waste of time and effort. Circumstances revolve around getting a job and getting their ideas accepted and used. Galder (1967) points out that the scientific skills and technology imparted to foreign students are often not applicable to the problems and conditions of developing countries. Meyer (1979: 17) suggested that extensive training toward a high degree of specialization in any of the above mid level skills has proven too sophisticated for many developing countries and therefore impractical to a returning third world student. And finally, Corey (1979), regarding the situation of Saudi Arabian students, expressed regret that curriculum content in American colleges were not relevant to the cultural, geographic, political or economic context of home countries. 
A fourth issue of relevance effects the decision of whether or not to remain in the $U$. S. The issue of relevance, or lack of relevance may in fact influence student decisions to stay after their American education is completed. If there were no jobs to return home to, students would consider their training for national development irrelevant In a study by Lee and Ray (1987: 75), the authors hypothesized

"...that the reasons why students might remain in theU.S.after their study differ according to their home country's politicoeconomic situations. In other words, some factors are more salient to students from certain countries than students from some other countries. We postulate that students' decisions to remain or not to remain in the $U$. S. depends on how they perceive the current situation and future prospects in their home country, which in turn might lead them to consider the prospects in the $U$. S. as alternatives to returning home."

The authors compared students from the countries of Iran, Nigeria, Taiwan and Venezuela. These four countries had distinct politico-economic situations in 1979, the time of this study. Nigeria was a rising OPEC nation with abundant employment opportunities. Venezuela was more stable than the other three. Iran was at the end of the Shah regime. Taiwan was in a state of uncertainty due to its relationship with the People's Republic of China. (Tables 5, 6)

Findings show that students' intentions of returning to their country depend on their perceptions of the situation at home moreso than on personal characteristics. When a developing country is stable and needs highly educated persons, students are more likely 
to return. They are especially more likely to return if the salaries match the middle class lifestyle in the U.S. This is the case for Nigeria. The case in Iran would have been similar were it not for the drastic changes in that country in the late 1970's. On the other hand, political turmoil, more than job opportunity influenced students from Taiwan and Venezuela to return home or remain in the U.S. Summarily, the best assurance for students returning home to a developing country is to create a stable political environment. Such an environment allows students access to rewarding positions that make good use of U.S. training. This is not likely in the near future and should be a consideration for colleges and universities in determining admissions policy and curriculum planning. The aims and intentions of curriculum otherwise cannot be met and investment benefits toward a nation's social and economic development would be lost.

A final issue regards the programs and solutions adopted by American colleges in developing a relevant curriculum for international students. As stated, the demand for higher education and trained manpower from developing countries has resulted in a flow of students to the U.S. The question arises what are the changes and services of the American College curriculum to meet this influx? Then, to what extent do foreign students utilize this education for economic development and what is the level of curriculum relevance toward that need? (Meyer, 1979: 18) So, curriculum relevance centers around the opportunity to explain the foreign national needs to U.S. faculty, to use technical and trade 
skills for development, and to adapt training to the home situation. In addition relevance may include application of $U$. S. problem solving in its own rural or ghetto poverty areas to the home nation. $U$. S. educators in the areas of agriculture, business, health, engineering or education need to be aware of their national problems to present valuable information. In all, curriculum relevance toward national development requires the following services and curriculum requirements in U. S. colleges (Taylor, 1979: 188-190):

1. training in technical skills,

2. practical on the job training,

3. English language instruction,

4. training in education and teaching to impart their skills at home,

5. awareness of developing countries' needs by American colleges (eg. through bringing projects and faculty from other countries),

6. developing indigenous solutions to problems,

7. providing training for leadership roles they will assume at home,

8. developing programs for educational opportunities in the home country.

Curriculum relevancy meets national development needs through the view and experience of the developing nations themselves. A survey of responses from developing nations who had sent students for development training in the U. S. (Taylor, 1979: 20-25) indicated a common theme of overspecialization and 
sophistication without regard to specific local situtations. One approach in meeting development needs and improving occupational and technical education is the direct contracting with foreign nations for mid level training only (Hoeck, 1982). In contracting with a developing nation, colleges can set up consortiums to supply specific services requested. The creation of Commnity College Cooperative for International Development, Inc. is one American response to provide mid level training and technical assistance for contracting nations. The organization seeks financial agreements with such developing nations as China, Dominican Republic, Jamaica, Nigeria, Surinam, Mexico, Kuwait and Egypt. The contracts include funding for training, housing, counseling, tuition and administrative costs. This trend in the west coast states of Washington and California has influenced the international curriculum of community colleges, intercultural interaction, mid level training and $U$. S. international relations.

\section{INTERNATIONAL EDUCATION AND THE COMMUNITY COLLEGE}

Florida community colleges have been in the forefront in participating in successful consortia programs (McClean, 1990; Greene, 1990; King, 1990). The Community Colleges for International Development and College Consortium for International Studies, for example, provide technical assistance and offer overseas opportunities for $U$. S. students in 18 foreign countries. 
They believe overseas educational experience is more effective in reaching objectives of international education (historical and global perspectives, language study, cross cultural communication and national devleopment). Community colleges have also established two year college programs abroad. Broward Community College in particular has campuses in Europe (Seville, Marbella, Madrid, Athens) and the Pacific rim (Malaysia, Singapore). These campuses offer general education college credit courses for visiting Americans and foreign students seeking a local American education before they transfer to an American campus.

The focus for foreign technical aid is the Community College for International Development (CCID). The CCID is a consortium of 44 U. S. and Canadian community colleges whose aim is providing mid level manpower training and technical assistance to developing nations. Its objectives also include student and faculty exchanges to ease technology training and transfer. These changes in community colleges reflect world changes and perceptions of how colleges should relate to new international conditions. It is a growing involvement of mutual benefit to developing countries, local communities and community colleges through educational opportunities, student and institutional development and foreign investment.

Community colleges have been playing an increasingly significant role in this trend toward international education (Yarrington, 1978; Fersh, 1986; Greene, 1984; Edwards, 1990; Scanlon, 1990; Gleazer, 1989; Adams, 1982). The rising enrollment 
of foreign students in America prompted a study by William G. Shannon (1976) which identified international/intercultural programs in community colleges and suggested how to replicate and strenghthen such programs. Primarily, his study showed the value and potential for links between community colleges and the international business community. It was in the 1980's however that widespread recognition of the significant role of the community college in international education came into existence. A momentous and influential study at this time was Barbara Burn's Expanding the International Dimensiion of Higher Education (1980). As international education expanded rapidly in the 1980's, many community colleges established "sister" relationships with colleges in Latin America, Europe and Asia. They offered technical assistance to these regions and created international business programs, helping local business to become more adequately involved in the international market place. The parameters of international studies and foreign languages became even more necessary when considering the impact of the international economy on local communities (Scanlon, 1990: 5-16).

Meeting the goals of international education in the community college also involves implementation of strategies at the classroom level (Edwards, 1990: 17-26). There are numerous organizations offering syllabi, handbooks, bibliographies and materials to help modify course content toward a more international approach. Academic disciplines would move beyond the Eurocentric approach and providing insignts from Asia, Latin America, Africa and the 
Middle East, the origin of the large majority of community college students.

Equally important at the classroom level of community college international education is instructional planning of an effective mix of methods and alternatives in accommodating different groups of students. There are many roads and ways to learning as students bring with them a variety of talents and learning styles to college. This is especially so with foreign students who represent a wide spectrum of cultures and personalities. Educational learning styles and perceptions are based on a set of cultural assumptions, values and beliefs. Major elaborations on learning styles include the Grasha-Riechmann taxonomy (Hoover, 1980: 86-88), Myers-Briggs Type Indicator (Meyers, 1962), and Concrete-abstract and Sequential-random dimensions (Gregorc, 1986). They have served to aid teachers in being sensitive to a cultural basis for learning and in developing instructional strategies that meet both American and foreign student needs.

Florida has become a nationwide leader in developing international education in American community colleges. Greene (1984-85, 1990) has outlined the various international programs offered at South Florida's Broward Community College. They range from in house English as a Second Language, to an international education component required in the general education sequence, to technical assistance and the community college abroad. This particular dimension involves an arrangement with the College 
Consortium for International Studies in the cities of Seville, Marbella, Madrid, Athens and Buenos Aires. Campuses at these locations offer general education college credit courses for visiting Americans and foreign students seeking a local American education before they transfer to an American campus. Broward has also established a campus in Malaysia and Singapore since an increasing number of Malaysian students were studying in the U.S. This is in keeping with the Florida State Community College International Mission Statement of 1990 . The misision is to provide global studies, technical assistance and training abroad, and expansion of all appropriate international education activities in Florida community colleges (International Education Institute, 1990).

Another example of the community college movement toward international education is the experience of the Maricopa Community Colleges in Arizona. Their Strategic Plan for International Education (1987) outlined a mission statement and listed strategies to serve as a guide in an ever increasing interconnected world. Recommendations and strategies include developing intenational/intercultural course content, providing faculty and student learning experiences, building communication with business and industry, collaborating with international consortia and establishing sister-institution relations with schools in other countries.

In all, though many community colleges have instituted the dimensions of international education on their compuses, a large majority have not begun (Quimbita, 1989: 2). Gleazer (1989) 
recommends several similar strategies to intitiate and expand international education in community colleges. His strategies involve presidents, board members and administrators; provide faculty with funds for curriculum and professional development; establish international education departments and committees; utilize community business resources; encourage faculty and student exchanges; participate in consortium arrangements; relate international education to the overall program and mission of the college.

\section{SUMMARY}

We have reviewed the literature on the education of foreign students in the U.S. and the view of what is a relevant education. The integration of six areas of research has led to the development of a research questionnaire used in this dissertation. The six areas are the following:

1. characteristics and needs of foreign students,

2. structure of a relevant curriculum in higher education,

3. dimensions of the international education curriculum,

4. international education in the community college,

5. issues of curriculum relevance for foreign students,

6. perceptions of level of satisfaction on curriculum relevance. 
Each area above pertains to issues of curriculum relevance. Most research literature on foreign students has been in the area of their characteristics, needs and adjustment problems. Solmon and Young (1987) and Zikopoulos (1991) described the general characteristics of foreign students and their impact toward international education on American College campuses. The major contributions for this study on relevance are the works of Kleinberg and Hull (1979), Meyer (1979) and Lee (1981). These studies contributed much to the development of the research questionnaire and understanding of student perception of relevance. Many studies (Meleis, 1982; Patrick, 1983; NAFSA, 1988; Rawls and Akpanudo, 1981) indicated the need for improved communication in the recruiting process by matching programs of study with foreign student training needs. Other studies (Ogunbi, 1978; Moock, 1984; Maliyamkono et. al., 1982) show that foreign student experience in American colleges useful and thus relevant to their work at home as leader and change agent toward economic development.

This study owes much of its theoretical orientation to the dissertations of Ogunbi (1978), Ekpe (1980), Rowland (1990) and Timko (1990). Ogunbi (1978) indicated that students with definite career objectives prior to training experienced both greater academic success and greater interest in contributing to their country's national development. However, like many studies on relevance of the college curriculum for foreign students, it was not conclusive in showing a relation between educational training and socio-economic results. Ekpe (1980) surveyed the opinion of foreign 
students regarding the issue of relevance and their role in home country development. His focus was on comparison between foreign students from developed and developing nations. He found that students from developing countries were more socially motivated and perceived their skills applicable in their countries. The implications were that educational institutions should consider issues of development in developing nations and the training of foreign students. Rowland (1990) addressed the relevance of a particular area of study for foreign students, public health training. The major finding was overall satisfaction with the relevance of academic experience to personal objectives and their countries' health needs. Timko (1990) assessed the perception of graduate faculty on the educational needs of international graduate students. He concluded that academic program planners focus on curricular needs in an international student's education in both Departments of Agriculture and Education.

This dissertation differs from the above studies by its focus on the community college. Whereas other studies sought the views of graduate students, graduate faculty and specific areas of training, this dissertation seeks perception of community college international students. Are these students satisfied with the international education curriculum of the community college, their academic planning and the relevance of the community college curriculum to personal and home country needs? 
Chapter III

\section{THE RESEARCH DESIGN}

Through this study this researcher intended to determine the level of satisfaction with the relevance of the community college curriculum as perceived by foreign students. The method of research for this study was an "ex post facto" study or as Barnes describes it, an "after only study without controls" (Barnes, 1964: 65). Ex post facto studies are employed when variables are not manipulated but are chosen after the fact. In ex post facto studies, groups are chosen that differ according to variables selected and their different responses are recorded. Gay (1987: 247) explains ex post facto research as a type of descriptive research and refers to it as the causal-comparative method. Causal-comparative research attempts to determine the cause for differences between groups and studies both the effect and cause in retrospect. As this study was descriptive and exploratory, data collection included a group interview, open ended questionnaire, in depth personal interviews and survey questionnaire. Statistical techniques were used to analyze quantitative data from the survey and supplemented by qualitative data from the interviews and open ended questionnaire. Chapter III presents the hypotheses, rationale, setting, population and sample, and procedures followed in conducting this causal-comparative study. 


\section{STATISTICAL HYPOTHESES}

The following null hypotheses helped focus this study and guided data collection and analysis. For the quantitative survey questionnaire the hypotheses was tested at the .05 alpha level to fulfill the objectives of this dissertation.

Ho $1=$ There is no significant difference between foreign students from represented developing nations and their perceived level of satisfaction with program services offered at the community college.

Ho $2=$ There is no significant difference between foreign students from represented developing nations and their perceived level of satisfaction with the relevance of the curriculum offered at the community college.

Ho $3=$ There is no significant difference between foreign students from represented majors and their perceived level of satisfaction with program services offered at the community college.

Ho $4=$ There is no significant difference between foreign students from represented majors and their perceived level of satisfaction with the relevance of the curriculum offered at the community college. 


\section{RATIONALE}

There are fundamental reasons for determining the results of the above hypotheses. It is expected that a causal relationship exists between a foreign student's country of origin and his/her perceived level of satisfaction with program services and curriculum relevance at the community college. It is also expected that a causal relationship exists between a foreign student's program of study and his/her perceived level of satisfaction with program services and curriculum relevance. Thus there are individual, institutional and global concerns to be considered. That there exists both a causal relationship between variables and differing levels of satisfaction with program services and curriculum relevance has implications for the community college. It has implications for the support of values expressed in its college catalog: providing advisement and counseling, respecting cultures, assessing program effectiveness and surveying student perceptions (Miami-Dade Community College, 1991: 5-6). In addition it has implications for the international education curriculum and international development. The community college may need to further consider appropriate curriculum and services for foreign students. It may need to further assess the structure and dimensions of the international education curriculum. Are the goals and objectives of the curriculum and the skills learned appropriate to the home country? In other words, is there national 
development through an American education, and are there in fact jobs in the home country for which foreign students are training? Therefore, the rationale for this study includes meeting needs of individual students, reassessing institutional services and curriculum, and determining the role of community colleges in international development.

\section{SETTING}

Miami-Dade Community College is a state supported two year college with five campuses located in metropolitan Dade County, Florida. The five campuses are North, South, Wolfson, Medical Center and Homestead. Miami-Dade has an Open Door Admissions Policy and encourages community residents and persons from other states and foreign countries to enroll. Among the values expressed in its 1991-92 catalog which help guide its mission and goals are values of learning, diversity and a sytematic approach to decision making. To support these values, the college 1) provides advisement and counseling to support student needs, 2) respects individuals from various cultures, 3) assesses program effectiveness, and 4) surveys student perceptions about courses and programs (Miami-Dade Community College, 1991: 5-6).

The enrollment in the fall of 1991-92 totalled 122,166 (Miami-Dade Community College, 1991) with 55,539 credit students (Morris, 1992: 16). Of these credit students, $10.5 \%$ or 5,757 are 
foreign students from 125 countries (Zikopoulos, 1991: 46). Latin America contributes $87 \%$ of this College's international enrollment whereas Asia contributes $54 \%$ of the national foreign student enrollment (Baldwin, 1991: viii). Florida ranks second to California in the number and percent of international students in two year colleges. According to the Miami-Dade Department of Institutional Research, there were 8,529 international students in Florida two year colleges in 1990. Close to two-thirds were enrolled at MiamiDade Community College (Baldwin, 1991: 13). International students can be separated into three groups: 1)Visa students, 2) refugee students and 3) resident aliens. In the Fall of 1991, of the total number of foreign students, 1,697 were Visa students. Visa students are those who reside in the United States only for permission to attend an American College full time and have the intention of returning home.

\section{POPULATION AND SAMPLE}

This study intended to focus on visa students representing three nations of the Caribbean Basin: the Bahamas, , Colombia and Haiti, and one from Asia: Pakistan. Visa students on the North Campus number 436, compared to 1697 college wide. The following is a distribution of the number of visa students from each of the above countries. It is listed by the Miami-Dade Community College Department of Institutional Research. The total population college- 
wide is 175 (Baldwin, 1991: 43) and 12,492 nationwide (Zikopoulos, 1990: 25).

North Campus College-Wide Nation-Wide

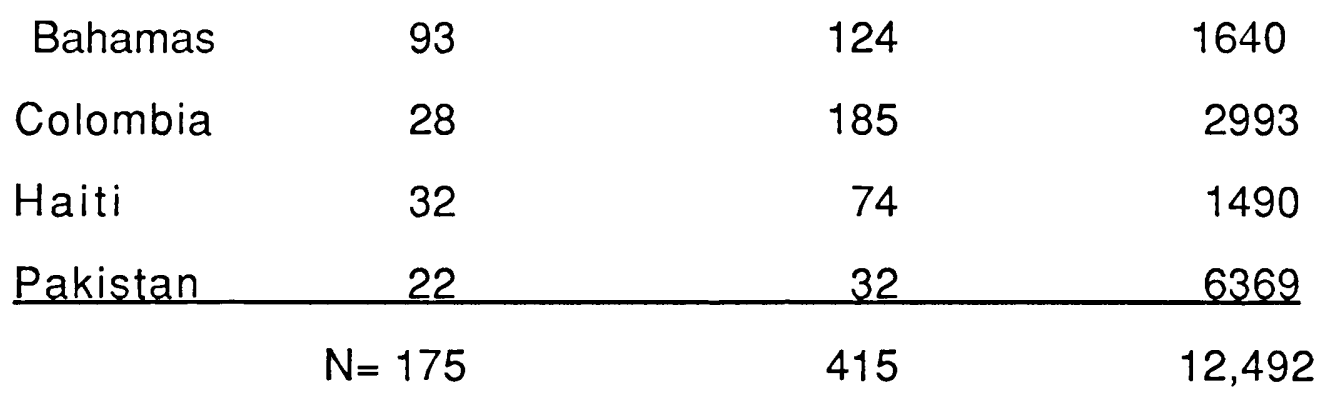

All students under study at the North Campus were $F 1$ Visa students. They were enrolled in credit courses and had been enrolled for at least one semester. The above groups also reflected the ethnic and racial groups that attend the North Campus. In the fall of 1991, the ethnic categories of the North Campus was predominantly Black non Hispanic (36.6\%) and Hispanic (44.2\%) . Asians represented the second largest population of all five campuses (Morris, 1992: 29). The large majority of students from the Bahamas and Haiti are black. Columbians are Hispanic and Pakistanis are Asian. In addition, according to the Miami-Dade Community College Office of Institutional Research, Blacks and Hispanics represent $19.2 \%$ and $55.2 \%$ of the college-wide population, respectively (Morris, 1992: 16). Table $D$ indicates the ethnic breakdown by each of the five campuses. The table shows that the predominance of any one ethnic/racial group exists on two campuses: South (hispanic) and Homestead (white). Thus, the North Campus more adequately reflects the ethnic headcount college-wide. The countries chosen for study also represent the multilingual 
character of Miami-Dade: English (Bahamas), Spanish (Colombia), Creole/French (Haiti) and Urdu (Pakistan).

\section{PROCEDURES}

The North Campus Department and Director of International Students supplied a list of student addresses and phone numbers for each country. I contacted each student by mail and phone in order to gather students by country for a group interview. I then administered an open ended questionnaire. (Appendix E) These two qualitative techniques were developed using the review of the literature. The group interview inquired into issues affecting student decisions. Issues included reasons for studying at MiamiDade Community College, educational and career objectives, and which aspects of services and curriculum the students found most or least relevant (Appendix E). The open ended questionnaire asked for personal information and those experiences that might influence students decisions to remain in the United States and influence their perceptions of curriculum relevance (Appendix E).

I also conducted in depth personal interviews with one or two representatives from each nation. This augmented the open ended questionnaire by personal elaboration and additional details of experiences and perceptions. I first contacted other student groups as a pilot test of the group and open ended questionnaire. These students were from Panama, Spain, Hong Kong and Japan. After the 
pilot test, with committee consultation, I adjusted the wording of questions and administered the interview and questionnaire to students of the four chosen countries. The student groups also completed a third questionnaire, a Likert-type scale indicating perceptions of the level of satisfaction of college services and curriculum (Appendix E). The questionnaire consists of 24 questions, 8 regarding personal information, 6 regarding college services and 10 regarding curriculum. The model for this questionnaire was the M. Y. Lee national survey of 1981 (Lee, 1981). In this survey, Lee attempted to assess the needs of foreign students nationwide. The areas investigated included meeting personal needs and relevance of a U.S. degree programs. Students indicated the two variables of country and major. They are presented by the numbers:

\section{Country of Origin:}

1. the Bahamas

2. Colombia

3. Haiti

4. Pakistan

Major Program of Study:

1. Business Administration

2. Computer Science

3. Hotel Management

4. Liberal Arts

5. Health Related Science

6. Science 


\section{Education}

8. Vocational

9. Engineering

10. English

Majors declared by students were grouped into three categories. This is due to the small numbers for certain majors which prohibit statistical analysis. The groups are A. Business: Business Administration, Hotel Management; B. Technology: Health, Engineering, Computer Science, Vocational; C. PreUniversity: English, Education, Liberal Arts, Science.

\section{QUALITATIVE AND QUANTITATIVE ANALYSIS OF DATA}

This writer employed both qualitative and quantitative approaches to this research. Group interview, open ended questionnaire and in depth personal interviews are components that serve to enhance the content of statistical information that the survey questionnaire presents. Theoretically, interpreting perception of community college services and curriculum through interview and open ended questionnaire by country, employs an ethnographic attempt to describe cultural perspective. In a sense this phenomenological orientation uses subjective interpretation and analysis of how individuals of different cultures behave and understand their daily experience in the cultural setting of the community college. (Bogdan, 1982: 35). This combines with more 
objective quantitative data to balance the analysis. Through such a balanced analysis of the data, a more disciplined and generally relevant dissertation was attained. Both quantitative and qualitative data and analysis complemented each other toward accuracy by virtue of each "watching" the other. (Lofland, 1984: 147).

\section{LIMITATIONS AND CONSTRAINTS}

The issues of external and internal validity represent the two major constraints of this research design. How results are generalized and accurately measured is the concern of external validity. The four countries of focus do have a national representation as noted in the sample above. The small sample of this research may limit the results and generalization to MiamiDade Community College. However, the sample of North Campus does represent a more adequate representation of the ethnic categories of students attending Miami-Dade college-wide as noted in TABLE D. It should also be realized that although this college has the highest enrollment of international students in the United States, the enrollment of $F 1$ Visa students does not rank high. In order to draw further conclusions from the data, a larger sample of students and schools may be needed.

Questions for the group interview and open ended questionnaire were developed and guided by the review of the literature. Personal 
information questions were used as a pilot for the survey questionnaire. Additional questions for the survey questionnaire were part of a 1981 nationwide study to assess needs of foreign students by Dr. Motoko Y. Lee of lowa State University. Only the use of standardized survey instruments could determine if the questionnaires were accurately measuring specific areas of interest. Based on alpha scores from the Lee study (Appendix G), there is confidence that the scores obtained are consistent with the previously administered questionnaire.

The problems of history, testing effect, mortality, bias and statistical inferences are the concerns of internal validity. Consequently, there were frequent contact with students, through mail, phone and group meetings to limit problems of history, testing effect and mortality. In addition, I employed the computer statistical package "Statview" for purposes of data analysis.

\section{SUMMARY}

Respondents in this study were those selected $F 1$ Visa students from three nations of the Caribbean Basin and one from Asia that attend Miami-Dade Community College, North Campus. The methods of group interviews, personal interviews, open ended questionnaire and survey questionnaire were utilized to assess international student perceptions regarding the level of satisfaction of college program services and curriculum relevance. 
The personal and group interviews focused on specific experiences and issues effecting individual decisions and perception of satisfaction. The open ended questionnaire inquired into personal information and perceptions of specific services and specific aspects of the curriculum. The survey questionnaire was designed to collect information on variables needed to accept or reject the null hypotheses. The variables are country of origin and major program of study. Additional variables were analyzed for descriptive intentions. Each of the methods, qualitative and quantitative, served as validating purposes to further assess the accuracy of perceptions on the level of student satisfaction. 


\section{ANALYSIS}

This chapter presents and analyzes both the qualitative and quantitative data collected. The objective of this research was to determine if foreign students from four nations were satisfied with services and curriculum offered at Miami-Dade Community College. Three sections below describe the findings of the study:

1. A description of the sample studied

2. Qualitative data

3. Quantitative data: perceived levels of satisfaction according to country and major

\section{DESCRIPTION OF SAMPLE STUDIED}

The total number of respondents from the 175 international students listed by the Department of Institutional Research is described through a series of distribution tables. There are eight variables of personal information from the International Student Survey. They are country of origin, age, sex, marital status, major, belief in a job being available upon returning home, possibility of remaining in the United States and expected degree. Tables 7 through 14 below serve this purpose. 
TABLE 7

\section{DISTRIBUTION ACCORDING TO COUNTRY}

NUMBER

\begin{tabular}{lccc}
\hline BAHAMAS & 23 & 24.7 & 93 \\
COLOMBIA & 16 & 57.1 & 28 \\
HAITI & 18 & 56.3 & 32 \\
PAKISTAN & 14 & 63.6 & 22 \\
\hline TOTAL & & & \\
\hline
\end{tabular}

TABLE 8

DISTRIBUTION ACCORDING TO AGE

$18-25 \% \quad 26-35 \% \quad 36-45 \quad \% \quad 46+\quad \%$

\begin{tabular}{lrrrrrrrr}
\hline BAHAMAS & 16 & 69.6 & 7 & 30.4 & 0 & 0 & 0 & 0 \\
COLOMBIA & 15 & 93.8 & 0 & 0 & 1 & 6.2 & 0 & 0 \\
HAITI & 12 & 66.6 & 4 & 22.2 & 2 & 11.1 & 0 & 0 \\
PAKISTAN & 11 & 78.5 & 3 & 21.4 & 0 & 0 & 0 & 0 \\
\hline & & & & & & & & \\
TOTAL & 54 & 76.1 & 14 & 19.7 & 3 & 4.2 & 0 & 0 \\
\hline
\end{tabular}


TABLE 9

DISTRIBUTION ACCORDING TO SEX

MALE $\%$ FEMALE $\%$ TOTAL $\%$

\section{BAHAMAS}

COLOMBIA

HAITI

PAKISTAN

12

10

10

1285.7

$44 \quad 61.97$

52.2

62.5

55.6

85.7
TOTAL

$27 \quad 38.03$

$71 \quad 100$

TABLE 10

\section{DISTRIBUTION ACCORDING TO MARITAL STATUS}

SINGLE MARR SEPAR DIVOR WIDOW TOTAL

BAHAMAS

COLOMBIA

HAITI

PAKISTAN

$\begin{array}{ll}21 & 1 \\ 15 & 1 \\ 14 & 1 \\ 14 & 0\end{array}$

64

$\begin{array}{ll}1 & 1 \\ 1 & 0 \\ 1 & 1 \\ 0 & 0\end{array}$

1
0
1
0

0
0
1
0

$\begin{array}{ll}0 & 23 \\ 0 & 16 \\ 1 & 18 \\ 0 & 14\end{array}$

TOTAL

3

2

1

1

71 
Table 7 indicates that 71 out of 175 students, or $40.6 \%$ of the total, responded to the survey. The highest percentage of response was the student group from Pakistan. There is a Student Association of Pakistan (S.A.P.) on the North Campus which was most anxious to participate in this survey. The lowest percentage of response was the student group from the Bahamas. These students are not represented by a student organization and did not experience the unity and enthusiasm for this study as compared to the other groups. The large majority of respondents $(76.1 \%)$ are in the $18-25$ age group (Table 8). Though community college students are generally older than traditional college students in the United States, international students are more in keeping with the younger age categories. This is also the case of the 71 students of this study. Likewise, due to the younger population, the large majority of students were single (Table 10). The marital status table shows only 3 were married, 4 separated, divorced or widowed, and 64 were single. The personal characteristic described in Table 9 indicates that most of these international students are male, or a 44/27 split. Only in the Bahamian student group was there a more equitable distribution, $52.2 \%-47.8 \%$. The Pakistani group was most predominantly one gender with 12 of 14 respondents male or $85.7 \%$. Third world countries are generally male dominated cultures.

Tables $11 \mathrm{~A}, 11 \mathrm{~B}$ and $11 \mathrm{C}$ give a breakdown of majors declared by each of the respondents. The highest percentage was Business Administration. This is comparable to the progams declared by all Visa students on all Miami-Dade Community College campuses found 
TABLE $11 \mathrm{~A}$

DISTRIBUTION ACCORDING TO MAJOR

BUS \%COMSCI \% HOTMT \% LIBART \% HLTH \%

$\begin{array}{lllllllllll}\mathrm{BAH} & 8 & 34.8 & 1 & 4.3 & 1 & 4.3 & 2 & 8.6 & 3 & 13\end{array}$

$\begin{array}{lllllllllll}\mathrm{CO} & 5 & 31.25 & 2 & 12.5 & 0 & 0 & 1 & 6.25 & 2 & 12.5\end{array}$

$\begin{array}{lllllllllll}\text { HAI } & 3 & 16.66 & 1 & 5.55 & 0 & 0 & 1 & 5.55 & 4 & 22.22\end{array}$

$\begin{array}{lllllllllll}\text { PAK } & 7 & 50 & 2 & 14.3 & 1 & 7.1 & 2 & 14.3 & 1 & 7.1\end{array}$

$\begin{array}{llllllllll}\text { TOTAL } 23 & 32.4 & 6 & 8.45 & 2 & 2.8 & 6 & 8.5 & 10 & 14.1\end{array}$

TABLE 11B

DISTRIBUTION ACCORDING TO MAJOR

SCI. \% EDUC. \% VOC. \% ENGIN. \% ENGL \%

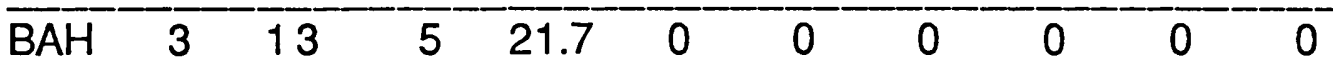

$\begin{array}{lllllllllll}\text { COL } & 1 & 6.25 & 1 & 6.25 & 0 & 0 & 4 & 2.5 & 0 & 0\end{array}$

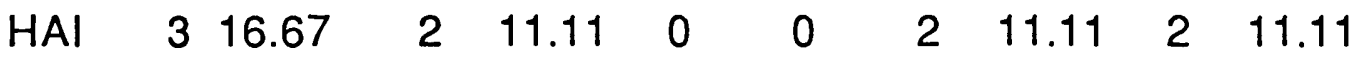

$\begin{array}{lllllllllll}\text { PAK } & 1 & 7.1 & 0 & 0 & 0 & 0 & 0 & 0 & 0 & 0\end{array}$

\begin{tabular}{llllllllll}
\hline TOTAL 8 & 11.27 & 8 & 11.27 & 0 & 0 & 6 & 8.5 & 2 & 2.82
\end{tabular} 


\section{DISTRIBUTION OF MAJORS/GROUPED}
A. BUSINESS
B. TECHNOL C. PRE-UNIVERSITY
BUS ADM
HLTH
ENGL
HOTMGM
ENGIN
EDUC
COMP SCI
LIB ART SCI TOTAL

\begin{tabular}{llrrr} 
BAHAMAS & 9 & 4 & 10 & 23 \\
COLOMBIA & 5 & 8 & 3 & 16 \\
HAITI & 3 & 7 & 8 & 18 \\
PAKISTAN & 8 & 3 & 3 & 14 \\
\hline & & 22 & 24 & $\mathbf{7 1}$
\end{tabular}

TABLE 12

DISTRIBUTION ACCORDING TO POSSIBILITY OF REMAINING IN U. S.

YES NO MAYBE TOTAL

BAHAMAS

COLOMBIA

HAITI

PAKISTAN
20
11
13
13

57

$\begin{array}{lll}3 & 0 & 23 \\ 1 & 4 & 16 \\ 1 & 4 & 18 \\ 1 & 0 & 14\end{array}$

TOTAL

6

8

71 
TABLE 13

DISTRIBUTION ACCORDING TO JOB AVAILABILITY AT HOME

YES ND MAYBE TOTAL

BAHAMAS

COLOMBIA

HAITI

PAKISTAN
6

7

8

3

24

14

33

23

16

18

14

TOTAL

$24-14$

$\begin{array}{rrr}6 & 11 & 23 \\ 4 & 5 & 16 \\ 1 & 9 & 18 \\ 3 & 8 & 14\end{array}$

TABLE 14

DISTRIBUTION ACCORDING TO EXPECTED DEGREE

A. A. A.S. CERTIF. NODEGREE TOTAL number $\%$ number $\%$ number $\%$ number $\%$ number $\%$

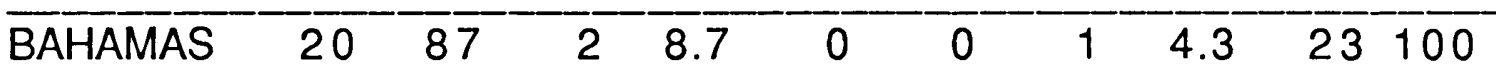

$\begin{array}{lllllllllll}\text { COLOMBIA } & 12 & 75 & 4 & 25 & 0 & 0 & 0 & 0 & 16 & 100\end{array}$

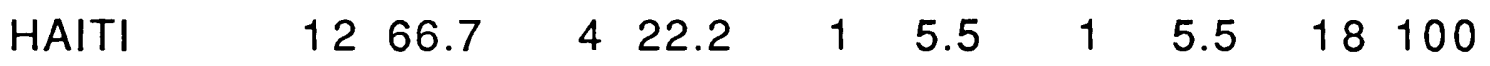

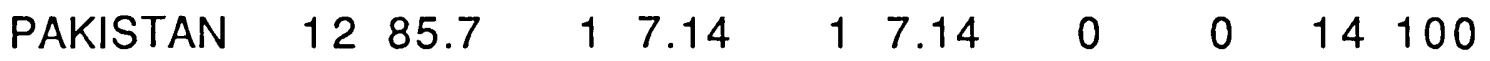

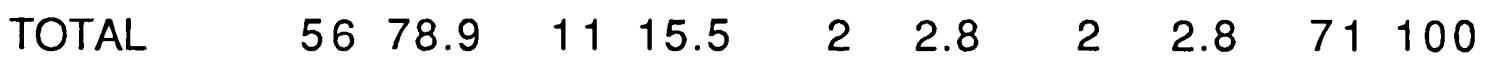


on Table $C$ in Appendix D. For matters of quantitative analysis, the declared majors needed to be grouped so that one-way analysis of variance would be mathematically possible. There were not enough numbers in the nine of ten majors declared for this statistical analysis. Table $11 \mathrm{C}$ groups the majors declared into three categories: 1. Business: Business Administration and Hotel Management; 2. Technology: Health, Engineering and Computer Science; 3. Pre-Univesity: English, Education, Liberal Arts and Science. Students did not declare vocational programs as a major. Finally, most international students expected to receive an Associate in Arts Degree. Because such a large percent of the international students surveyed expect an A. A., it made comparison of the perceived satisfaction of services and curriculum relevance according to expected degree moot if not unnecessary.

The International Student Survey asked if students believed they might remain in the U.S. (Table 12) or have a job upon their return home (Table 13). Tables 5 and 6 in Appendix $C$ outline these issues. Students were asked in personal and group interviews as well as on the open ended questionnaire to elaborate on these issues. Though all are Visa students and are studying at the community college with declared intent to return home, 57 of 71 students admit the possibility of remaining in the U.S. One of the main reasons for this decision is the availabiliity of a job upon their return and the offer of a job in the U. S. Only 24 of 71 students believe there will be a job available for them upon the return home. 


\section{QUALITATIVE DATA}

This study involved gathering data from international students through a variety of methods. Each method provided its own perspective and contribution to overall depth of information. Initially, there were four group interviews, one for each of the nations represented. The data collected from the group interviews is represented in a summary chart below. Second, students were given an open ended questionnaire in order to elaborate on specific questions pertaining to student perceptions. Questions included why students might remain in the $U$. S. and which specific personal services or courses in the curriculum did they find most or least relevant to their needs. They also explained which experiences they thought were most or least relevant to the needs of their home country. This data is represented in a matrix chart below. Finally, I interviewed four students, one from each country. A summary and analysis of their comments is also presented in this chapter.

\section{GROUP INTERVIEW AND OPEN DISCUSSION GUIDELINES}

\section{BAHAMAS}

1. What are your reasons for studying at a community college? (eg. social, patriotic, financial) 
FINANCIAL REASONS; ITS CLOSE TO THE BAHAMAS AND EASY TO GO HOME; WE HAVE FAMILY HERE.

2. What are the objectives of your education? (eg. obtain a specialization or vocational skill, technical skills, practical experience in field, leadership skills, administrative skills, promote change in your country)

MIAMI - DADE HAS A PROGRAM IN HOTEL MANAGEMENT AND WE HAVE A TOURISM INDUSTRY IN NASSAU; THERE'S ALOT OF INTERNATIONAL CONTACT HERE. I EXPECT A LEADERSHIP ROLE AT HOME BECAUSE OF MY EDUCATION IN MIAMI.

3. What type of work do you intend to do when you return home? HOTEL MANAGEMENT, WORK FOR THE GOVERNMENT, NURSING

4. What might influence you to remain in the U.S. (eg. job, marriage, problems at home)

IF I CAN WORK HERE OR MARRIAGE; FOR SOME NOTHING WOULD INFLUENCE THEM TO REMAIN ("THIS CAMPUS MAKES YOU FEEL LIKE 'SHIT; NOBODY CARES ABOUT YOU")

5. What courses in the curriculum have you found most or least relevant to your personal and career needs and interests? Why?

STATISTICS, BUSINESS AND ACCOUNTING ARE MOST RELEVANT; LIBERAL ARTS COURSES AND HUMANITIES ARE NOT RELEVANT.

6. What courses in the curriculum have you found most or least relevant to your country's needs? Why?

BUSINESS AND TECHNICAL COURSES ARE RELEVANT TO THE BAHAMAS. 
7. What experiences in the curriculum do you find most relevant that can be applied to the needs of your country? (eg. seminar, technical skills, on the job training, learning solutions found in America's community)

COMPUTER LABS

8. How satisfied are you with college services? (eg. health, housing, advising, counseling, information on college and American life)

ADVISERS WERE HELPFUL BUT MOSTLY DISSATISFIED WITH SERVICES, ESPECIALLY HOUSING AND HEALTH; NOBODY CARES HERE AND AMERICAN STUDENTS HAVE BAD VALUES; THE INTERNATIONAL STUDENT OFFICE IS A "WASTE."

\section{COLOMBIA}

1. What are your reasons for studying at a community college? (eg. social, patriotic, financial)

THERE IS AN ENGLISH PROGRAM HERE, PRE-COLLEGE ESL COURSES; IT'S CLOSE TO COLOMBIA; THERE ARE ALOT OF LATINS HERE, BUT IT'S HARD TO LEARN ENGLISH. EVERYONE SPEAKS SPANISH.

2. What are the objectives of your education? (eg. obtain a specialization or vocational skill, technical skills, practical experience in field, leadership skills, administrative skills, promote change in your country)

GO TO A UNIVERSITY - F.I.U., AND LEARN TECHNICAL AND COMPUTER SKILLS

3. What type of work do you intend to do when you return home?

ARCHITECT, ENGINEER, OWN A BUSINESS 
4. What might influence you to remain in the U.S. (eg. job, marriage, problems at home)

MARRIAGE, GETTING A GOOD JOB; THERE'S ALOT OF POLITICAL CONFLICT AT HOME AND ALOT OF CRIME.

5. What courses in the curriculum have you found most or least relevant to your personal and career needs and interests? Why?

COMPUTERS, ENGINEERING, BUSINESS COURSES; TEACHERS DON'T ASSOCIATE ENOUGH WITH STUDENTS.

6. What courses in the curriculum have you found most or least relevant to your country's needs? Why?

SOME MATH DOESN'T RELATE TO ENGINEERING; HUMANITIES

7. What experiences in the curriculum do you find most relevant that can be applied to the needs of your country? (eg. seminar, technical skills, on the job training, learning solutions found in America's community)

TECHNOLOGY AND COMPUTER SKILLS

8. How satisfied are you with college services? (eg. health, housing, advising, counseling, information on college and American life)

NOTHING WORKS RIGHT HERE; THIS WAS NOT MY IMAGE OF AN AMERICAN COLLEGE; DISSATISFIED BECAUSE YOU'RE NOT ADVISED PROPERLY AND HAVE TO FIGURE IT OUT YOURSELF; I PREFER THE SOUTH CAMPUS, IT HAS A BETTER ATMOSPHERE; THERE'S PREJUDICE AGAINST COLOMBIANS HERE; THEY THINK WE'RE ALL DRUG DEALERS. 


\section{HAITI}

1. What are your reasons for studying at a community college? (eg. social, patriotic, financial)

THERE'S A HAITIAN COMMUNITY IN MIAMI, SO THERE ARE SOCIAL REASONS; MIAMI - DADE IS EXPENSIVE FOR FOREIGN STUDENTS BUT CHEAPER THAN U.M. THERE'S AN ESL PROGRAM HERE.

2. What are the objectives of your education? (eg. obtain a specialization or vocational skill, technical skills, practical experience in field, leadership skills, administrative skills, promote change in your country)

LEADERSHIP AND ECONOMIC DEVELOPMENT IN HAITI IS VERY NECESSARY;

THINGS CAN'T CHANGE WITH THE PRESENT GOVERNMENT.

3. What type of work do you intend to do when you return home?

WORK IN BUSINESS; MY OWN PRIVATE BUSINESS; WORK FOR THE GOVERNMENT.

4. What might influence you to remain in the U.S. (eg. job, marriage, problems at home)

THE MILITARY GOVERNMENT IS NOT HELPFUL TO HAITI; THERE ARE RELATIVES IN MIAMI THAT INFLUENCE REMAINING HERE; THERE ARE JOBS HERE. THE U. S. GOVERNMENT QUICKLY WENT TO THE AID OF AQUINO IN THE PHILIPPINES WHEN THE MILITARY THREATENED TO TAKE OVER BUT DID NOTHING FOR HAITI.

5. What courses in the curriculum have you found most or least relevant to your personal and career needs and interests? Why? 
COURSES DEALING WITH YOUR MAJOR ARE RELEVANT LIKE BUSINESS AND HEALTH.

6. What courses in the curriculum have you found most or least relevant to your country's needs? Why?

HUMANITIES, MATH AND SCIENCE AREN'T RELEVANT; I LEARNED CALCULUS IN HIGH SCHOOL IN HAITI; WE HAVE GOOD SCHOOLS, THEY'RE BASED ON THE FRENCH SYSTEM OF EDUCATION.

7. What experiences in the curriculum do you find most relevant that can be applied to the needs of your country? (eg. seminar, technical skills, on the job training, learning solutions found in America's community)

ALL TECHNICAL SKILLS ARE VERY IMPORTANT; IT'S GOOD TO EXCHANGE INFORMATION ABOUT YOUR COUNTRY IN CLASS; YES, THERE IS AN INTERNATIONAL EDUCATION HERE.

8. How satisfied are you with college services? (eg. health, housing, advising, counseling, information on college and American life)

THERE AREN'T ADEQUATE SERVICES DEALING WITH HOUSING AND HEALTH CARE; EVERONE HAS BEEN VERY HELPFUL TOME, ALL YOU HAVE TO DO IS ASK.

\section{PAKISTAN}

1. What are your reasons for studying at a community college? (eg. social, patriotic, financial)

NOT ENOUGH COLLEGES IN PAKISTAN; THE IMAGE OF THE U.S. AND AN AMERICAN EDUCATION; COLLEGE GIVES YOU MORE OPORTUNITIES. 
2. What are the objectives of your education? (eg. obtain a specialization or vocational skill, technical skills, practical experience in field, leadership skills, administrative skills, promote change in your country)

PERSONAL SATISFACTION; SKILLS IN INTERNATIONAL BUSINESS AND MANAGEMENT.

3. What type of work do you intend to do when you return home?

OWN A BUSINESS; WORK FOR A LARGE INTERNATIONAL FIRM OR GOVERNMENT IN COMPUTER PROGRAMMING AND TECHNICAL SKILLS.

4. What might influence you to remain in the U.S. (eg. job, marriage, problems at home)

PROBLEMS AT HOME, POLITICS AND THE ECONOMY; I DON'T INTEND TO STAY HERE, BUT MAYBE NOT PAKISTAN EITHER.

5. What courses in the curriculum have you found most or least relevant to your personal and career needs and interests? Why?

SPEECH, PSYCHOLOGY, BUSINESS MANAGEMENT, COMPUTERS AND ACCOUNTING ARE MOST RELEVANT.

6. What courses in the curriculum have you found most or least relevant to your country's needs? Why?

THESE COURSES ARE RELEVANT TO JOB AND COUNTRY NEEDS.

7. What experiences in the curriculum do you find most relevant that can be applied to the needs of your country? (eg. seminar, technical skills, on the job training, learning solutions found in America's community)

TECHNICAL SKILLS LEARNED ARE NOT REALLY DIRECTLY RELATED TO PAKISTAN; SOMEWHAT OF AN INTERNATIONAL EDUCATION BUT NOT REALLY; I CAN TALK TO PROFESSORS ABOUT PAKISTAN 
AND INDIA AND BRING THESE TOPICS UP IN CLASS; THEY ENCOURAGE IT.

8. How satisfied are you with college services? (eg. health, housing, advising, counseling, information on college and American life)

NEGATIVE - ONLY ADVISING IS SATISFACTORY; THE SCHOOL IS TOO BUREAUCRATIC AND POLITICAL; THERE IS NO WAY THINGS WILL CHANGE FOR THE INTERNATIONAL STUDENT IN THE NEAR FUTURE, BUT WE ARE INTERESTED IN THE RESULTS OF YOUR STUDY; MAYBE IT CAN HELP FOR FUTURE STUDENTS FROM PAKISTAN; I HOPE THIS STUDY GETS INTO THE RIGHT HANDS SO THINGS CAN GET DONE.

\section{PERSONAL INTERVIEWS}

There were four students interviewed in conjunction with the open ended questionnaire and group interviews. Students representing each country and four different majors had the opportunity to describe in their own words their perception of satsifaction with services and curriculum relevance at the community college. The interviewees were a hotel mangement major from the Bahamas, an engineering major from Colombia, a business administration major from Haiti, and a computer science major from Pakistan. These interviews added depth and insights to the perceptions of international students attending Miami-Dade and into their daily experiences. 


\section{BAHAMAS}

The Bahamian student was a young female who had visited Miami on a number of previous occasions before deciding to enroll at Miami-Dade. Therefore she was somewhat familiar with this community. She intends to take a position in the Bahamian tourism industry after completing a degree in hotel management. Miami to her is of close proximity to Nassau both physically and culturally. There are many Caribbean people living here as well as relatives and friends. Planning to go to college in Miami was not a difficult decision since the Bahamas lacks college facilities, the U. S. has a good reputation for academics in higher education and Miami colleges offer good programs in hotel and restaurant management. In addition, it is easy to return to Nassau and see her parents. However, she was very disappointed with the indifference of the people at the North Campus. "It is not a friendly atmosphere. Noone cares about you here. They treat you like 'shit'." I suggested a small midwest college like the one I attended in Minnesota. She was very receptive to it and thought she would pursue that possibility if there was a hotel management program offered.

She said that services are almost non existent and noone gives you the time of day. You're ignored. Plus, advisors need to get their act together. They don't tell you the right procedures and lose letters and materials. Good housing is difficult to find and there is no information on health. Too many students are not there to learn and don't have the right attitude for a college education. They want 
to beat the system, don't want to work, and are rude and inconsiderate to both other students and teachers. Being a commuter school, it is hard to make acquaintances. Everyone does his/her thing and leaves by 1:00 or 2:00 P. M. She thought a campus environment with dormitories would be better. The courses she took were okay and seemed challenging. This student believed she would be well prepared to enter the Bahamian tourist industry and definitely wished to return home and not remain in the United States. However, there were still two more years of college at F.I.U. (Florida Int'l Unviersity) to complete.

\section{COLOMBIA}

This interviewee was a young engineering student anxious to express some of his experiences. He was highly motivated and career oriented. Overall, he expressed a rather negative perception of services offered but acknowledged his satisfaction with the relevance of the curriculum to both his career and needs of Colombia. Complaints centered around the inability to ever see an adviser and not being advised properly when he did have that opportunity. Consequently, he was almost forced to drop out of school. Both the bureaucratic nature of the school and impersonality contributed to his perception of little positive regard for international students. Specific examples include being forced to drop a course and not take an incomplete, and not being able to use the Star Service since he was an international student. Thus he had 
to do things the hard way, plan by himself through the catalogue and with little help. Excessive tuition for foreign students and being forced to have health insurance added to the frustration. He was acquainted with South Campus of Miami-Dade and believed it posessed a less impersonal and more positive, collegiate atmosphere.

There appeared to be an incongruence with the math and engineering courses, since the math teachers were not engineers. He felt there needed to be more application of math skills to engineering and more relevant computer programs taught. In terms of practical experience in the curriculum, this was not applied towards credit even though he did have engineering experience in his home country. Finally, he expressed dismay of the fact that he could never talk about Colombia in classes, had little association with faculty, and surprised at the ignorance of American students about Latin America. Apparently some students questioned the use of technology or paved roads there.

Because of the political and crime problems in Colombia it is possible he remain in the $U$. S. if offered a good position. However, because of the prejudice and reputation of Colombians in America, he still might return. In all, he became philosophical of his experience here. "You're on your own at M-DCC, North to find out for yourself and good luck. There's noone to help you out if you make a mistake." "In America," he continued, "the emphasis is on money and egoism. This is transplanted to foreign countries, changing them and the mentality of the people, ruining the culture. Instead of helping 
your country or economic development, students return with a selfish attitude. They ruin the country, the culture and only think of themselves, not society."

\section{HAITI}

The Haitian interviewee was a mature, 26 year old business administration student. At the outset he indicated that his dream of organizing business or bringing big business to Haiti could not be realized considering the present government. The government would not receive these efforts well and might even confiscate capital. Things are not secure and rather unjust. This motivates him to remain in Miami.

Overall he is very satisfied with his experience at Miami-Dade, North. It has a friendly atmoshere and you're given personal attention. Though there is always red tape, if you ask you could find solutions to all the regulations and procedures. Acknowledging that professors were not well acquainted with Haiti, he believed students need to input that information and use themselves as an example toward international perspectives. Professors are flexible in this regard. Probably the most relevant course experience for him was preparing a business plan, market survey and contact with community businesses. Also speaking before the class helped him greatly.

This student believes that in general Haitians have a positive view of the services and curriculum of the college and how it 
relates to Haiti. Haitians learn the language quickly, work hard and are high achievers. He noted that in math and geography, Haitian students were more advanced than American students. He also pointed out that Haitian students have community support in Miami.

\section{PAKISTAN}

The need to survive dominates the minds of Pakistani students according to a 20 year old computer science major. Most are working to get residency and find a job in their field. Most are working right now, illegally, and getting paid "under the table."

Services of the community college are "no good." Students get confused with the International Student Office. They walk in with one problem and walk out with three in their mind and are usually disappointed. He acknowledged that there may be some cultural conflict here. Usually Pakistanis are looking for solutions, while American counselors are trained to make clients aware of options and alternatives from which to choose. He believes the college is not run right with a confusing registration system and excessive bureaucracy. "It takes awhile to know the system and it's up to students to take the initiative to know it."

Major courses relate and are practical for Pakistan. In his opinion Humanities are also relevant courses but students are not aware of its scope and ideas affecting them. He sees the Pakistani students as westernized and adhere to the values, philosophies and concepts expressed in western literature and ideas. Non western 
perspectives were included in one of his social science courses. Being a mature and intelligent student, I suggested he read D'Souza's Illiberal Education.

"Life is very practical here. You can plan and put into action what you want. In Pakistan people talk and plan but can't do. Here you have the freedom and independence to do things, within boundaries." He is very concerned with the economic development of Pakistan and would like to work for a large multinational corporation. First he must continue toward a degree at Florida International University and stay in Miami for two more years. Like other Pakistani students at Miami-Dade, he doesn't want to leave Miami and move to another state. We're very satisfied with the education here.

\section{MATRIX CHARTS}

The matrix charts below are a summary and comparison of the responses to the open ended questionnaire. Bahamian students were generally critical of personal services, especially academic advisers. Though satisfied with major coursework and many courses, they expressed a regret that not enough was being done to help international students. Colombians were concerned about the political/economic situation at home. This combined with the increasing crime rate were motivating factors for remaining in the U. S. As far as the college was concerned, many were critical of counselling and academic advising. The financial limitations place 
on the international student office was understandable and appreciated what little that could be done. They complained of being rudely treated by clerical staff. The Hispanic student population is most dominant at South Campus and many expressed the possibility of transfer.

Haitians were also very concerned about the political situation at home. Both the recent military ouster of President Aristede and low level of socio/economic development made Haitian students believe there were better chances for them in the U.S. Though dissatisfied with the way of life in Miami, they were generally satisfied with both services and curriculum offered at the college. Being there is a Haitian community here, Haitians are not alien to Miami and many believe that they belong here.

Although Pakistan is a third world nation, Pakistani students at Miami-Dade are from westernized upper class families. They had higher standards than the other groups of students and expressed more criticism. They complained of the Miami-Dade bureaucracy and were split in their satisfaction with services. Highly motivated students, all were satisfied with many courses and planned to attend local universities after completing their studies at MiamiDade. 


\section{MATRIX CHART}

INFLUENCES

TO REMAIN IN

U.S. maybe if I happen to fall in love \& get married; job offers are possible; economic instability and political problems at home may keep me here; if I get my green card and can work, I'll stay; nothing would make me stay here.
SATISFACTION OFPERSONAL SERVICES college should provide housing for VISA students; very unsatisfied with academic advising; advisers are lacking in professional skill - they're more lost than the students; different advisers give different information and can mislead you; I'm generally satisfied with all services.
COURSES

MOST/LEAST

RELEVANT science courses are very relevant to my

nursing career; jobwise engineering courses relevant but not humanities; business courses are helpful to my country and me when I return; designing courses (architecture) make me think conceptually and be creative; everyone should learn basic math which should already have been learned in high school.
EXPERIENCES MOST/LEAST RELEVANT work experience increases my knowledge immensely; business courses will help me take a leadership role in my country; technical skills are very useful.

students; the college has alot to offer but appears to have a great amount of limitations; though very helpfulall around, not enough is done to help the international student; the British system is more dominant and it takes awhile to accept work done at college there. 
INFLUENCES

TO REMAIN

IN U.S. marriage might make me stay; it's a better financial situation in Miami; I plan to go back, but if I get a good job offer, I will stay; political situation is bad in Colombia; alot of crime.
SATISFACTION OFPERSONAL SERVICES some of the clerical staff (black) seem to have a negative attitude toward students; counseling and academic advising is satisfactory; information about life in America and on college is satisfactory; dissatisfied with international student office and int'l regulations; I could never see an adviser; you're on your own here.
COURSES

MOST/LEAST

RELEVANT
College Survival "SLS" was very helpful in finding information and organizing; statistics is relevant but not humanities; accounting labs allow us to apply what we learn; English courses are relevant because this is the future language; science ocurses are relevant because they are suited to my career; math courses are not applied to engineering and fortran is obsolete.
EXPERIENCES MOST/LEAST RELEVANT the opportunity for work experience in the U.S. is always welcomed by Colombia for job applicants; curriculum is too basic to apply to needs of my country; technical skills learned are relevant; I got work experience on my own, it's not offered at $M-D C C$.

I believe a combination of work experience and seminars can provide a good basis of information to apply to my country; there needs to be more encouragement and guidance from professors and better relations with int'l students from the int'l student office; this is very interesting, thanks for your concern for F1 VISA students and international students. 


\section{MATRIX CHART}

ITEMS

HAITI

INFLUENCES

TO REMAIN

IN U. S. there are many needs but the economy is too bad in Haiti; the political situation is very bad; the gov't makes things insecure; if my children were born in the U.S. , it would hard for them to adjust in Haiti; there are better chances for a job in the U.S. and no opportunities in Haiti; my family wants me to stay.
SATISFACTION OFPERSONAL SERVICES there's little academic advising and they give bad advice; many counselors are not helpful to newcomers; some advisers are helpful but I'm dissatisfied with the way of life in America; help was given whenever $\mathrm{I}$ requested and people were very helpful.
COURSES MOST/LEAST RELEVANT courses based on your major / career are relevant; psychology is good for business and nursing; English Comp. is a hassle; all courses helpful and worth knowing for Haiti; computer and math will be helpful; Humanities and phys. ed. are least relevant for career and economic development.
EXPERIENCES MOST/LEAST RELEVANT seminars in class are good and it's important to exchange information; technical skills learned are very important to apply to Haiti; opportunity for work experience, all valuable skills and knowhow are necessary in Haiti; my experiences with business have been very helpful. students start all over when they come here, no credit for work in Haiti; We should be allowed to work while studying for more experience when we return home; I had alot of public contact, you need to know how to deal with different social groups; without a progressive government, relevant courses mean nothing. 


\section{MATRIXCHART}

ITEMS

PAKISTAN

INFLUENCES

TO REMAIN

IN U.S. good jobs in America might keep me here; political/ economic conflict at home; I may live in another country; I have no intention of staying here; Miami way of life is not a desirable place to live.
SATISFACTION OFPERSONAL SERVICES not much personal attention here; I'm dissatisfied with most services; people are indifferent here and the $s$ school is too bureaucratic; no help in housing, counseling is poor; I've taken courses that were unnecessary; services were good for $\mathrm{me}$ and teachers helpful.
COURSES

MOST/LEAST

RELEVANT humanities and science are irrelevant but English, communication and computer are most relevant; all co courses seem to increase my knowledge in personal and career needs; social science courses need a broader vision; management and psychology courses are relevant for Pakistan because they help us apply the knowledge to our practical lives.
EXPERIENCES MOST/LEAST RELEVANT satisfied with computer courses and mgmt. skills; computer labs are very relevant; 1 can exchange information about my country to professors and discuss international topics; technical skills are relevant to job and needs of my country; speech communication and leadership programs are relevant. this research is cool; will this research be used to change things? $M-D C C$ is too political and won't change; they won't make an effort to meet needs of Pakistanior international students; I enjoy this kind of meeting very much; let me join one next time as well. 


\section{QUANTITATIVE DATA}

\section{PERCEIVED LEVELS OF SATISFACTION OF COLLEGE SERVICES ACCORDING TO COUNTRY AND MAJOR}

The following series of tables also statistically summarize the composite of questions pertaining to both program services and curriculum relevance. The summary of statistics include number, mean and standard deviation for these set of responses. The results for each set of responses are determined according to the variables of country of origin and major. Hypothesis Ho 1 states that there is no significant difference between foreign students of represented developing countries and their perceived level of satisfaction with program services offered at the community college. Hypothesis Ho 2 states that there is no significant difference between foreign students of represented developing countries and their perceived level of satisfaction with the relevance of the curriculum offered at the community college. Hypothesis Ho 3 states that there is no significant difference between foreign students of represented college majors and their perceived level of satisfaction with program services offered at the community college. Hypothesis Ho 4 states that there is no significant difference between foreign students of represented college majors and their perceived level of satisfaction with the relevance of the curriculum offered at the 
TABLE 15A

THE COLLEGE OFFER OF ADEQUATE SERVICES

TO AID IN ADJUSTMENT TO LIFE IN U. S.

$\begin{array}{lll}\text { COUNTRY NUMBER MEAN S.D. } & \text { MN }\end{array}$

$\begin{array}{lrrr}\text { BAHAMAS } & 23 & 3.87 & 1.217 \\ \text { COLOMBIA } & 16 & 4 & 0.816 \\ \text { HAITI } & 18 & 3.833 & 1.791 \\ \text { PAKISTAN } & 14 & 4.5 & 1.286\end{array}$

$\begin{array}{llll}\text { TOTAL } & 71 & 4.014 & 1.325\end{array}$

TABLE 15B:

THE COLLEGE OFFER OF ADEQUATE SERVICES

TO AID IN ADJUSTMENT TO LIFE IN U. S.

MAJOR

NUMBER

MEAN

S.D.
A. BUSINESS
25
4.12
1.269
B. TECHNOLOGY
22
4.128
1.593
C. PRE-UNIVERSITY
24
3.75
1.113

TOTAL 
TABLE 16A

COMMUNITY AND HEALTH SERVICES

AVAILABLE TO FOREIGN STUDENTS AND FAMILIES

COUNTRY

NUMBER

MEAN

S.D.

BAHAMAS

COLOMBIA

23

4.913

1.379

HAITI

16

4.688

1.014

18

4.833

1.823

PAKISTAN

14

4.786

1.051

TOTAL

71

4.817

1.356

TABLE 16B

COMMUNITY AND HEALTH SERVICES

AVAILABLE TO FOREIGN STUDENTS AND FAMILIES

MAJOR

NUMBER

MEAN

S.D.
A. BUSINESS
25
5
1.08
B. TECHNOLOGY
22
4.545
1.625
C. PRE-UNIVERSITY
24
4.875
1.361

TOTAL

71

4.817

1.356 
community college. Consequently, four one way anova tables statistically determined if there is a significant difference between the means in these sets of questions. For further analysis, matrix charts have indicated both oral and written responses to the group interview and open ended questionnaire. Another section in this chapter reported and analyzed the information gathered from personal interviews. This qualitative approach served to aid in evaluation of how program services and curriculum relevance were perceived.

The reliability scores of survey questionnaire items are presented in Table D. Cronbach's coefficient alpha values estimated the reliability of items pertaining to satisfaction of services and curriulum relevance. Scores for these items were supplied by $\mathrm{Dr}$. Motoko Y. Lee based on her nationwide 1981 study (Lee, 1981: 46). Reliability estimates for composite of questions regarding needs in services and curriculum ranged from .64 to .86 .

Six questions pertained to student satisfaction with college services. Tables 15A, 15B through 20A, 20B indicate number, mean and standard deviation for each response according to country and major. As is the case college-wide, most respondents were Bahamian and business students. The numbers were too small for statistical analysis for many majors declared, especially for Hotel Management and English. Therefore, the means tables represent majors group according to these categories: A. Business- business administration and hotel management; B. Technology- health, 
TABLE 17A

THE OPPORTUNITY TO ASSESS ACADEMIC AND PERSONAL CAREER NEEDS WITH COUNSELORS AND ADVISORS

$\begin{array}{lll}\text { COUNTRY NUMBER } & \text { MEAN }\end{array}$

$\begin{array}{llll}\text { BAHAMAS } & 23 & 3.696 & 1.717 \\ \text { COLOMBIA } & 16 & 3.312 & 0.873 \\ \text { HAITI } & 18 & 3.056 & 1.056 \\ \text { PAKISTAN } & 14 & 4.929 & 1.207\end{array}$

TOTAL

71

3.69

1.44

TABLE 17B

THE OPPORTUNITY TO ASSESS ACADEMIC AND PERSONAL CAREER NEEDS WITH COUNSELORS AND ADVISORS MAJ'OR
A. BUSINESS
25
3.88
1.394
B. TECHNOLOGY
22
3.273
1.453
C. PRE-UNIVERSITY
24
3.875
1.454

TOTAL

71

3.69

1.44 
TABLE 18A

AVAILABILITY OF INFORMATION AND PROCEDURES

IN PLANNING THE COLLEGE PROGRAM

COUNTRY

NUMBER

MEAN

S.D.

BAHAMAS

COLOMBIA

HAITI

PAKISTAN
23

16

18

14

71
3.696

3

3.056

4.429

3.521
1.46

0.894

1.211

1.222

TOTAL

1.329

TABLE 18B

AVAILABILITY OF INFORMATION AND PROCEDURES IN PLANNING THE COLLEGE PROGRAM

MAJOR

NUMBER

MEAN

S.D.
A. BUSINESS
25
3.64
1.381
B. TECHNOLOGY
22
3.182
1.332
C. PRE-UNIVERSITY
24
3.708
1.268

TOTAL 
engineering, and computer science; C. Pre-University- English, education, liberal arts and science. As noted above and in Table 11, there were no respondents for a vocational major.

Students responded to questions according to the following scale: $1=$ very satisfied, $2=$ quite satisfied, $3=$ satisfied, $4=$ undecided, $5=$ unsatisfied, $6=$ quite unsatisfied, $7=$ very unsatisfied. Students were neither satisfied nor unsatisfied with the college offer of adequate services to aid in adjustment to life in the U. S. (Tables 15A and 15B). However, Pakistanis registered the closest response to unsatisfied (4.5). There was a small difference between the scores for business, technology and pre-university majors. Pakistani students appeared to have a closer bond than the other national groups and from a higher socio-economic level. They expressed in their group interview higher standards expected from the community college.

All groups by country and major were dissatisfied with the community and health services available to foreign students and families (Tables 16A, 16B). The mean average was 4.817 or close to level 5 (unsatisfied) in the scale. This was corroborated in the qualitative interviews above.

Although many expressed in interviews a dissatisfaction with the opportunity to assess academic and personal career needs with counselors and advisors, only the Pakistani group did so in the survey questionnaire (Tables 17A, 17B). In fact, both Haitians (3.056) and technology students (3.273) showed satisfaction with this aspect of community college services. It is not the purpose of 
this paper to determine a significant difference for each question or item, but rather the series of items. But, in this instance there was a significant difference between the Pakistani national group and the groups from Colombia and Haiti (Table 17C).

Likewise, Tables 18A, 18B, 18C show a significant difference in responses for the same national groups. Students from Colombia (3.00) and Hait (3.056) are satisfied with the availability of information and procedures in planning the college program. Pakistanis (4.429) expressed some dissatisfaction. This could be partly explained by the fact that many Pakistani students are business majors as opposed to technology majors. Technology majors had a more favorable response on this item. These were two of three items in the quantitative research section that were statistically significant.

There was a slight favorable edge in level of satisfaction for faculty members spending time for association or guidance by liberal arts majors (Table 19B). Liberal arts staff being known to be humanistically oriented may account for this slight difference. There was also unanimous agreement toward dissatisfaction by country and major for receiving credit for academic work done outside the U. S. (Tables 20A, 20B). The mean for this item was 4.507 and with less variablility in the responses. It had one of the smaller standard deviation, .939 . 
TABLE 17C ONE WAYY ANALYSIS OF VARIANCE

THE OPPORTUNITY TO ASSESS ACADEMIC AND PERSONAL CAREER NEEDS WITH COUNSELORS AND ADVISORS

$\begin{array}{llllll}\text { SOURCE } & \text { DF } & \text { SUMOFSQ. } & \text { MEANSQ. } & \text { F } & \text { P } \\ \text { BETWEENGROUPS } & 3 & 31.003 & 10.334 & 6.064 & .001 \\ \text { WITHIN GROUPS } & 67 & 114.18 & 1.704 & & \\ \text { TOTAL } & 70 & 145.183 & & \end{array}$

COMPARISON

BAHAMAS V. COLOMBIA

BAHAMAS V. HAITI

BAHAMAS V. PAKISTAN

COLOMBIA V. HAITI

COLOMBIA V. PAKISTAN

HAITI V. PAKISTAN
MEAN DIFF.

$\begin{array}{rl}0.383 & 0.271 \\ 0.64 & 0.809 \\ -1.233 & 2.588 \\ 0.257 & 0.109 \\ -1.616 & 3.814^{\star} \\ -1.873 & 5.404^{\star}\end{array}$

*SIGNIFICANT AT $<.05$

TABLE $18 \bar{C}$ ONE WAY ANALY $\bar{S} \bar{S}$ OF VARIANTEE

AVAILABILITY OF INFORMATION AND PROCEDURES

IN PLANNING THE COLLEGE PROGRAM

$\begin{array}{llllll}\text { SOURCE } & \text { DF } & \text { SUMOFSQ. } & \text { MEANSQ. } & \text { F } & \text { P } \\ \text { BETWEENGROUPS } & 3 & 20.476 & 6.825 & 4.429 & .0067 \\ \text { WITHIN GROUPS } & 67 & 103.243 & 1.541 & & \\ \text { TOTAL } & 70 & 123.718 & & & \end{array}$

COMPARISON

BAHAMAS V. COLOMBIA

BAHAMAS V. HAITI

BAHAMAS V. PAKISTAN

COLOMBIA V. HAITI

COLOMBIA V. PAKISTAN

HAITI V. PAKISTAN
MEAN DIFF.

$\begin{array}{rl}0.696 & 0.988 \\ 0.64 & 0.895 \\ -0.733 & 1.011 \\ -0.056 & 5.655 \\ -1.429 & 3.296^{\star} \\ -1.373 & 3.211^{\star}\end{array}$

*SIGNIFICANT AT <.05 
TABLE 19A

FACULTY MEMBERS SPENDING TIME FOR ASSOCIATION OR GUIDANCE

COUNTRY

NUMBER

MEAN

S.D.

BAHAMAS

COLOMBIA

HAITI

PAKISTAN
23

16

18

14

71
3.87
3.562
3.611
3.643

1.359

0.814

1.539

1.277

TOTAL

3.69

1.272

TABLE 19B

FACULTY MEMBERS SPENDING TIME FOR ASSOCIATION OR GUIDANCE

$\begin{array}{lll}\text { MAJOR NUMBER } & \text { MEAN }\end{array}$
A. BUSINESS
25
3.92
1.152
B. TECHNOLOGY
22
3.682
1.492
C. PRE-UNIVERSITY
24
3.458
1.179

TOTAL

71

3.69

1.272 
TABLE 20A

RECEIVING CREDIT FOR ACADEMIC

WORK DONE OUTSIDE THE U. S.

COUNTRY

NUMBER

MEAN

S.D.

BAHAMAS

23

4.696

0.926

COLOMBIA

16

4.375

0.957

HAITI

18

4.222

1.06

PAKISTAN

14

4.714

0.726

TOTAL

71

4.507

0.939

TABLE 20B

RECEIVING CREDIT FOR ACADEMIC

WORK DONE OUTSIDE THE U. S.

MAJOR

NUMBER

MEAN

S.D.
A. BUSINESS
25
4.6
0.866
B. TECHNOLOGY
22
4.5
1.102
C. PRE-UNIVERSITY
24
4.417
0.881

TOTAL

71

4.507

0.939 


\section{PERCEIVED LEVEL OF SATISFACTION OF THE RELEVANCE OF THE COMMUNITY COLLEGE CURRICULUM ACCORDING TO COUNTRY AND MAJOR}

Students perceived relevance of the community college curriculum at a more satisfactory level than services. Interviews, discussions and open ended questions all resulted in satisfactory examples of relevant courses and experiences. Patterns in statistical tables $21 \mathrm{~A}, \mathrm{~B}$ through $30 \mathrm{~A}, \mathrm{~B}$ also recognized this positive tone. The research of Timko (1990), Ekpe (1980) and Rowland (1990) focused on educational needs and curriculum relevance of international graduate students. Training at the community college level is not as sophisticated as graduate school but there is the opportunity for an international approach to the curriculum offered. For many of these items listed there was a higher level satisfaction in the relevance of the community college curriculum to personal and home country needs. This I believe is a result of the efforts of departments and faculty to implement an international curriculum. It is a part of the international conciousness given the large foreign constituency at Miami-Dade Community College and the city of Miami, and the influence of curriculum innovations at local universities. Nevertheless, there was no statistical difference in the means of each item as well as the means of the composite series of items (Tables $31 \mathrm{~A}, \mathrm{~B}, \mathrm{C}, \mathrm{D}$ ).

All categories of students by nation or major perceived the curriculum as relevant to their future job in the home country. 
TABLE 21A

COLLEGE CURRICULUM RELEVANT TO

YOUR FUTURE JOB IN YOUR COUNTRY

$\begin{array}{lll}\text { COUNTRY NUMBER MEAN S.D. } & \text { MEN }\end{array}$

$\begin{array}{llll}\text { BAHAMAS } & 23 & 2.652 & 1.112 \\ \text { COLOMBIA } & 16 & 2.562 & 0.964 \\ \text { HAITI } & 18 & 2.833 & 1.339 \\ \text { PAKISTAN } & 14 & 3.071 & 0.917\end{array}$

TOTAL

71

2.761

1.101

TABLE 21B

COLLEGE CURRICULUM RELEVANT TO YOUR FUTURE JOB IN YOUR COUNTRY

MAJOR

NUMBER

MEAN

S.D.
A. BUSINESS
25
2.68
0.945
B. TECHNOLOGY
22
3
1.272
C. PRE-UNIVERSITY
24
2.625
1.096

TOTAL

71

2.761

1.101 
TABLE 22A

OPPORTUNITIES TO GIVE INFORMATION

ABOUT YOUR COUNTRY IN CLASSES

COUNTRY

NUMBER

MEAN

S.D.

BAHAMAS

COLOMBIA

HAITI

PAKISTAN
23

16

18

14

71

3.761

3.739

3.562

3.667

4.143

1.389

1.153

1.414

1.167

TOTAL

-

TABLE 22B

OPPORTUNITIES TO GIVE INFORMATION ABOUT YOUR COUNTRY IN CLASSES

MAJOR

NUMBER

MEAN

S.D.
A. BUSINESS
25
3.8
1.472
B. TECHNOLOGY
22
3.682
1.323
C. PRE-UNIVERSITY
24
3.792
1.103

TOTAL

71

3.761

1.292 
With a mean of 2.761 , scores ranged from 2.562 to 3.071 , all on the level of quite satisfied to satisfied (Tables 21A, 21B). Opportunities to give information about your country in classes did not fair as well (Tables 22A, 22B). This item's mean of 3.761 indicates a score in between undecided and satisfied.

During the interviews many students believed that certain courses were more conducive to such dialogues. Further, certain teachers are more receptive to discussion including perspectives from other countries. The Haitian interviewee in particular felt it a responsibility of the student to offer such information; that is, international perspectives were a responsibility of the student as well as the professor.

Perhaps including international materials in courses is not an automatic given. Most students were undecided in this matter (4.239), but Pakistanis scored closest to unsatisfied with a mean of 4.857 and technology majors scored 4.364 (Tables 23A, 23B). Colombians were closer to satisfied with a mean score of 3.688 . This contradicts the Colombian interviewee who was not satisfied with the international content in his engineering classes. Similarly, the community college is not an environment of extensive intellectual exchange or debate. It is not one of its main purposes to train for national economic development, except perhaps domestically. This sample was again undecided in the availability of seminars dealing with national development. Pakistanis were the closest to unsatisfied in this regard with a mean score of 4.929 (Tables 24A, 24B). 
TABLE 23A

CURRICULUM THAT INCLUDED

INTERNATIONAL MATERIALS IN COURSES

COUNTRY

NUMBER

MEAN

S.D.

BAHAMAS

23

4.565

1.343

COLOMBIA

16

3.688

0.873

HAITI

18

3.833

1.383

PAKISTAN

14

4.857

0.949

TOTAL

71

4.239

1.259

TABLE 23B

CURRICULUM THAT INCLUDED

INTERNATIONAL MATERIALS IN COURSES

MAJOR NUMBER MEAN S.D.
A. BUSINESS
25
4.2
1.19
B. TECHNOLOGY
22
4.364
1.364
C. PRE-UNIVERSITY
24
4.167
1.274

TOTAL

4.239

1.259 
TABLE 24A

AVAILABILITY OF SEMINARS DEALING

WITH PROBLEMS OF NATIONAL DEVELOPMENT

$\begin{array}{llll}\text { COUNTRY } & \text { NUMBER } & \text { MEAN } & \text { S.D. } \\ & & & \\ \text { BAHAMAS } & 23 & 4.391 & 1.196 \\ \text { COLOMBIA } & 16 & 4.125 & 1.204 \\ \text { HAITI } & 18 & 4.167 & 1.505 \\ \text { PAKISTAN } & 14 & 4.929 & 1.385\end{array}$

TOTAL

71

4.381

1.324

TABLE 24B

AVAILABILITY OF SEMINARS DEALING WITH PROBLEMS OF NATIONAL DEVELOPMENT

MAJOR

NUMBER

MEAN

S.D.
A. BUSINESS
25
4.48
1.295
B. TECHNOLOGY
22
4.182
1.593
C. PRE-UNIVERSITY

TOTAL

71

4.381

1.324 
TABLE 25A

COLLEGE CURRICULUM RELEVANT

TO NEEDS OF YOUR COUNTRY

COUNTRY

NUMBER

MEAN

S.D.

BAHAMAS

23

2.913

1.125

COLOMBIA

16

3.375

0.806

HAITI

PAKISTAN

18

$3.556 \quad 1.294$

$\begin{array}{lll}14 & 4.286 & 1.267\end{array}$

TOTAL

71

3.451

1.216

TABLE 25B

COLLEGE CURRICULUM RELEVANT

TO NEEDS OF YOUR COUNTRY

MAJOR

NUMBER

MEAN

S.D.
A. BUSINESS
25
3.44
1.158
B. TECHNOLOGY
22
3.591
1.403
C. PRE-UNIVERSITY
24
3.333
1.129

TOTAL

71

3.451

1.216 
Yet, many in the sample believed the college curriculum relevant to the needs of their country (Tables 25A, 25B). Bahamians and pre-university education majors in particular were most satisfied. The area of the curriculum most relevant to country needs was technology. All in this sample were satisfied with the level of technology taught as applicable to the future of their country (Tables 26A, 26B). Graduate students sometimes believe the level of technology transferred as too sophisticated for a developing nation. This sometimes results in a brain drain. This issue does not pertain to the community college.

Did Miami-Dade Community College offer a curriculum including training to introduce changes or for a leadership role in their country? (Tables 27A, 27B, 28A, 28B) Students perceived these two items in the survey questionnare as satisfied. They scored means of 3.239 and 3.197, respectively. Again there were no siginificant differences for these items.

The item receiving the score closest to unsatisfied in the series of questions related to curriculum relevance was in Tables $29 \mathrm{~A}$ and 29B. One component of international education is the exchange of professors between countries. Pakistanis scored the highest for this item, 5.429 and an analysis of variance (Table 29C) indicated it a significant difference, especially as compared to the Colombian score, 4.188. This was confirmed by the conservative Scheffe F-Test of 2.874 The overall level of response was 4.634 . Through various kinds of agreements, there are visiting professors from other countries at Miami-Dade. As reported by the 
TABLE 26A

LEVEL OF TECHNOLOGY APPLICABLE

TO THE FUTURE OF YOUR COUNTRY

COUNTRY

NUMBER

MEAN

S.D.

BAHAMAS

23

2.696

0.876

COLOMBIA

16

2.75

0.683

HAITI

18

2.778

1.166

PAKISTAN

14

3

1.109

TOTAL

71

2.789

0.955

TABLE 26B

LEVEL OF TECHNOLOGY APPLICABLE

TO THE FUTURE OF YOUR COUNTRY

MAJOR

NUMBER

MEAN

S.D.
A. BUSINESS
25
2.68
0.852
B. TECHNOLOGY
22
2.91
1.109
C. PRE-UNIVERSITY
24
2.79
0.932

TOTAL

71

2.789

0.955 
TABLE 27A

CURRICULUM INCLUDING TRAINING TO

INTRODUCE CHANGES IN YOUR COUNTRY

COUNTRY

NUMBER

MEAN

S.D.

BAHAMAS

COLOMBIA

23

3.261

1.054

HAITI

16

3.438

0.814

PAKISTAN

18

3.111

1.491

14

3.143

1.099

TOTAL

71

3.239

1.127

TABLE 27B

CURRICULUM INCLUDING TRAINING TO

INTRODUCE CHANGES IN YOUR COUNTRY

MAJOR

NUMBER

MEAN

S.D.
A. BUSINESS
25
3.08
0.997
B. TECHNOLOGY
22
3.5
1.336
C. PRE-UNIVERSITY
24
3.167
1.049

TOTAL

71

3.239

1.127 
TABLE 28A

CURRICULUM INCLUDING TRAINING FOR A LEADERSHIP ROLE IN YOUR COUNTRY

COUNTRY

NUMBER

MEAN

S.D.

BAHAMAS

COLOMBIA

23

3.174

1.193

HAITI

16

3.375

0.806

PAKISTAN

18

3.222

1.353

14

3

1.109

TOTAL

71

3.197

1.129

TABLE 28B

CURRICULUM INCLUDING TRAINING FOR A LEADERSHIP ROLE IN YOUR COUNTRY

MAJOR

NUMBER

MEAN

S.D.
A. BUSINESS
25
2.96
0.935
B. TECHNOLOGY
22
3.545
1.224
C. PRE-UNIVERSITY
24
3.125
1.191

TOTAL

71

3.197

1.129 
TABLE 29A

THE EXCHANGE OF VISITING PROFESSORS BETWEEN

UNIVERSITIES OF YOUR COUNTRY AND THIS COLLEGE

COUNTRY

NUMBER

MEAN

S.D.

BAHAMAS

COLOMBIA

23

16

4.652

1.265

HAITI

PAKISTAN

18

4.188

0.655

4.389

1.378

14

5.429

1.089

TOTAL

71

4.634

1.21

TABLE 29B

THE EXCHANGE OF VISITING PROFESSORS BETWEEN UNIVERSITIES OF YOUR COUNTRY AND THIS COLLEGE

MAJOR

NUMBER

MEAN

S.D.
A. BUSINESS
25
4.84
1.214
B. TECHNOLOGY
22
4.591
1.469
C. PRE-UNIVERSITY
24
4.458
0.932

TOTAL

71

4.634

1.21 
TABLE 29C: ONE WAY ANALYSIS OF VARIANCE

THE EXCHANGE OF VISITING PROFESSORS BETWEEN UNIVERSITIES OF YOUR COUNTRY AND THIS COLLEGE

SOURCE

BETWEENGROUPS

WITHIN GROUPS

TOTAL
DF SUMOFSQ. MEANSQ.

13.118

89.361 102.479
4.373

1.334
70
COMPARISON
MEAN DIFF.

0.465

0.263

$-0.776$

$-0.201$

$-1.241$

$-1.04$
SCHEFFE- F
BAHAMAS V. COLOMBIA

BAHAMAS V. HAITI

BAHAMAS $V$. PAKISTAN

COLOMBIA V. HAITI

COLOMBIA V. PAKISTAN

HAITI V. PAKISTAN
0.509

0.175

1.311

0.086

$2.874^{*}$

2.127

\section{${ }^{*}$ SIGNIFICANT AT <.05}

Department of Institutional Research (Baldwin, 1991: 53) $72.9 \%$ of all visa students enrolled at Miami-Dade are from Latin America. This includes South America, Central America and the Caribbean. Most visiting professors are from Caribbean Basin countries. Apparently there are no agreements between institutions in Pakistan and Miami-Dade. 
Since community college courses are at an introductory level, there is less opportunity for practical experience in one's major field. As a result, students were undecided in this matter (Tables 30A, 30B). However, the Haitian group perceived this as satisfied with a mean of 3.111. As explained in the review of the literature, practical experience is a significant component of a relevant college education. Haitians believe they receive adequate and relevant experience during their years at Miami-Dade. Interestingly, but also not statistically significant, the results also show that the visa students from Haiti as most satisfied with their college education for both services and curriculum relevance (Tables 31A, 31B).

\section{TESTS OF HYPOTHESES}

The first hypothesis, Ho 1 , states there is no significant difference between foreign students from represented developing nations and their perceived level of satisfaction with program services offered at the community college. Table $31 \mathrm{~A}$ is the total mean of the series of questions related to satisfaction of college servicesby country. The 7 point scale satisfaction mean average is 4.04 , with the lowest score of 3.769 (Haiti) and highest score of 4.5 (Pakistan). At first observation none of the mean averages varies from the category of undecided, neither satisfied or unsatisfied. Considering that the Pakistani culture is most varied from the 
TABLE 30A

OPPORTUNITY FOR PRACTICAL EXPERIENCE

IN YOUR FIELD BEFORE RETURNING HOME

COUNTRY

NUMBER

MEAN

S.D.

BAHAMAS

COLOMBIA

HAITI

PAKISTAN
23

16

18

14

71
3.957

4.312

3.111

3.857

3.803
1.492

1.448

1.53

1.512

TOTAL

71

1.527

\section{TABLE 30B \\ OPPORTUNITY FOR PRACTICAL EXPERIENCE \\ IN YOUR FIELD BEFORE RETURNING HOME}
MAJOR
NUMBER
MEAN
S.D.
A. BUSINESS
25
3.76
1.393
B. TECHNOLOGY
22
3.727
1.778
C. PRE-UNIVERSITY
24
3.917
1.472

TOTAL

71

3.803

1.527 
TABLE 31A

MEAN OF THE SERIES OF QUESTIONS RELATED TO

SATISFACTION OF COLLEGE SERVICES BY COUNTRY

COUNTRY

NUMBER

MEAN

S.D.

$\begin{array}{lrrr}\text { BAHAMAS } & 23 & 4.123 & 0.878 \\ \text { COLOMBIA } & 16 & 3.823 & 0.569 \\ \text { HAITI } & 18 & 3.769 & 1.085 \\ \text { PAKISTAN } & 14 & 4.5 & 0.592\end{array}$

TOTAL

71

4.04

0.858

TABLE 31B

MEAN OF THE SERIES OF QUESTIONS RELATED TO

SATISFACTION OF CURRICULUM RELEVANCE BY COUNTRY

COUNTRY

NUMBER

MEAN

S.D.

$\begin{array}{lrrr}\text { BAHAMAS } & 23 & 3.6 & 0.705 \\ \text { COLOMBIA } & 16 & 3.537 & 0.504 \\ \text { HAITI } & 18 & 3.467 & 0.994 \\ \text { PAKISTAN } & 14 & 3.971 & 0.533\end{array}$

TOTAL

71

3.625

0.732 
Caribbean cultural influence of Miami-Dade might explain the higher score toward unsatisfied. However, the results of a one way analysis of variance (Table 32A) reveal at a .05 level of significance, no significant difference between the selected countries. This is indicated by an $\mathrm{F}$ value of 2.505 and probability of .0665 . The probability was a marginal level, yet we accept the null hypothesis.

The second hypothesis, Ho 2, states there is no significant difference between foreign students from represented developing nations and their perceived level of satisfaction with the relevance of the curriculum offered at the community college. Table $31 \mathrm{~B}$ is the total mean of the series of questions related to satisfaction of curriculum relevance by country. The 7 point scale satisfaction mean average is 3.625 , with the lowest score of 3.476 (Haiti) and highest score of 3.971 (Pakistan). The Haiti score registers closer the level of satisfaction while the Pakistan score registers closer to undecided on the 7 point scale. However, as in the previous results of a one way analysis of variance, table 32B reveals at .05 level of significance, no significant difference between the selected countries. This is indicated by an $\mathrm{F}$ value of 1.4398 and probability of .2392. Therefore we accept the null hypothesis.

The third hypothesis, Ho 3 , states there is no significant difference between foreign students from represented major progams of study and their perceived level of satisfaction with program services offered at the community college. Table $31 \mathrm{C}$ is the total mean of the series of questions related to satisfaction of 
TABLE 31C

MEAN OF THE SERIES OF QUESTIONS RELATED TO

SATISFACTION OF COLLEGE SERVICES BY MAJOR/GROUPED

MAJOR

NUMBER

MEAN

S.D.

A. BUSINESS

25

4.193

0.739

B. TECHNOLOGY

22

3.894

0.999

C. PRE-UNIVERSITY

24

4.014

0.845

TOTAL

71

4.04

0.858

TABLE 31D

MEAN OF THE SERIES OF QUESTIONS RELATED TO

SATISFACTION OF CURRICULUM RELEVANCE BY MAJOR/GROUPED

MAJOR

NUMBER

MEAN

S.D.

\begin{tabular}{llll}
\hline A. BUSINESS & 25 & 3.592 & 0.593 \\
B. TECHNOLOGY & 22 & 3.709 & 0.884 \\
C. PRE-UNIVERSITY & 24 & 3.583 & 0.734
\end{tabular}

TOTAL

71

3.625

0.732 
college services by major/grouped. The 7 point scale satisfaction mean average is 4.04 , with the lowest score of 3.894 (Technology) and highest score of 4.193 (Business). These scores register close to the level of undecided on the 7 point scale. Again, as in the previous results of a one way analysis of variance, table $32 \mathrm{C}$ reveals at .05 level of significance, no significant difference between the majors. This is indicated by an $\mathrm{F}$ value of .723 and probability of .4892 . Thus we accept the null hypothesis.

The fourth hypothesis, Ho 4, states there is no significant difference between foreign students from represented major progams of study and their perceived level of satisfaction with the relevance of the curriculum offered at the community college. Table $31 \mathrm{D}$ is the total mean of the series of questions related to satisfaction of curriculum relevance by major/grouped. The 7 point scale satisfaction mean average is 3.625 with the lowest score of 3.583 (Pre-University) and highest score of 3.709 (Technology). These scores also register close to the level of undecided on the 7 point scale. Again, as in the previous results of a one way analysis of variance, table 32D reveals at .05 level of significance, no significant difference between the majors. This is indicated by an $F$ value of .205 and probability of .8153 . Thus we accept the fourth null hypothesis.

From the results of this study we can determine perceptions held by community college international students regarding their satisfaction of services and relevance of the curriculum offered. Qualitative data was gathered from students with a variety of 
TABLE 32A

ONE WAY ANALYSIS OF VARIANCE FOR SERIES OF QUESTIONS RELATED TO SATISFACTION OF COLLEGE SERVICES BY COUNTRY

\begin{tabular}{|c|c|c|c|c|c|}
\hline $\begin{array}{l}\text { SOURCE } \\
\text { BETWEEN GROUPS } \\
\text { WITHIN GROUPS } \\
\text { TOTAL }\end{array}$ & $\begin{array}{l}\text { DF } \\
3 \\
67 \\
70\end{array}$ & $\begin{array}{l}\text { SUM OF SQ. } \\
5.202 \\
46.379 \\
51.581\end{array}$ & $\begin{array}{l}\text { MEANSQ. } \\
1.734 \\
0.692\end{array}$ & $\begin{array}{l}F \\
2.505\end{array}$ & $\begin{array}{c}P \\
.0665\end{array}$ \\
\hline \multicolumn{2}{|c|}{$\begin{array}{l}\text { COMPARISON } \\
\text { BAHAMAS V. COLOMBIA } \\
\text { BAHAMAS V. HAITI } \\
\text { BAHAMAS V. PAKISTAN } \\
\text { COLOMBIA V. HAITI } \\
\text { COLOMBIA V. PAKISTAN } \\
\text { HAITI V. PAKISTAN }\end{array}$} & $\begin{array}{r}\text { MEAN DIFF. } \\
0.3 \\
0.355 \\
-0.377 \\
0.054 \\
-0.677 \\
-0.731\end{array}$ & $\begin{array}{r}\text { SCHEFF- } \\
0.6 \\
0.6 \\
0.5 \\
0.0 \\
1.6 \\
2.0\end{array}$ & & \\
\hline
\end{tabular}

\section{$\overline{T A} \overline{B L E} 3 \overline{2} \bar{B}$}

ONE WAY ANALYSIS OF VARIANCE FOR SERIES OF QUESTIONSRELATED TO SATISFACTION OF CURRICULUM RELEVANCE BY COUNTRY

$\begin{array}{lrrrrr}\text { SOURCE } & \text { DF } & \text { SUMOFSQ. } & \text { MEANSQ. } & F & P \\ \text { BETWEEN GROUPS } & 3 & 2.268 & 0.756 & 1.4398 & .2392 \\ \text { WITHIN GROUPS } & 67 & 35.206 & 0.525 & & \\ \text { TOTAL } & 70 & 37.474 & & & \end{array}$

$\begin{array}{lrl}\text { COMPARISON } & \text { MEAN DIFF. } & \text { SCHEFFE- } \bar{F} \\ \text { BAHAMAS V.COLOMBIA } & 0.062 & 0.023 \\ \text { BAHAMAS V. HAITI } & 0.133 & 0.114 \\ \text { BAHAMAS V. PAKISTAN } & -0.371 & 0.762 \\ \text { COLOMBIA V. HAITI } & 0.071 & 0.027 \\ \text { COLOMBIA V.PAKISTAN } & -0.434 & 0.892 \\ \text { HAITI V. PAKISTAN } & -0.505 & 1.273\end{array}$




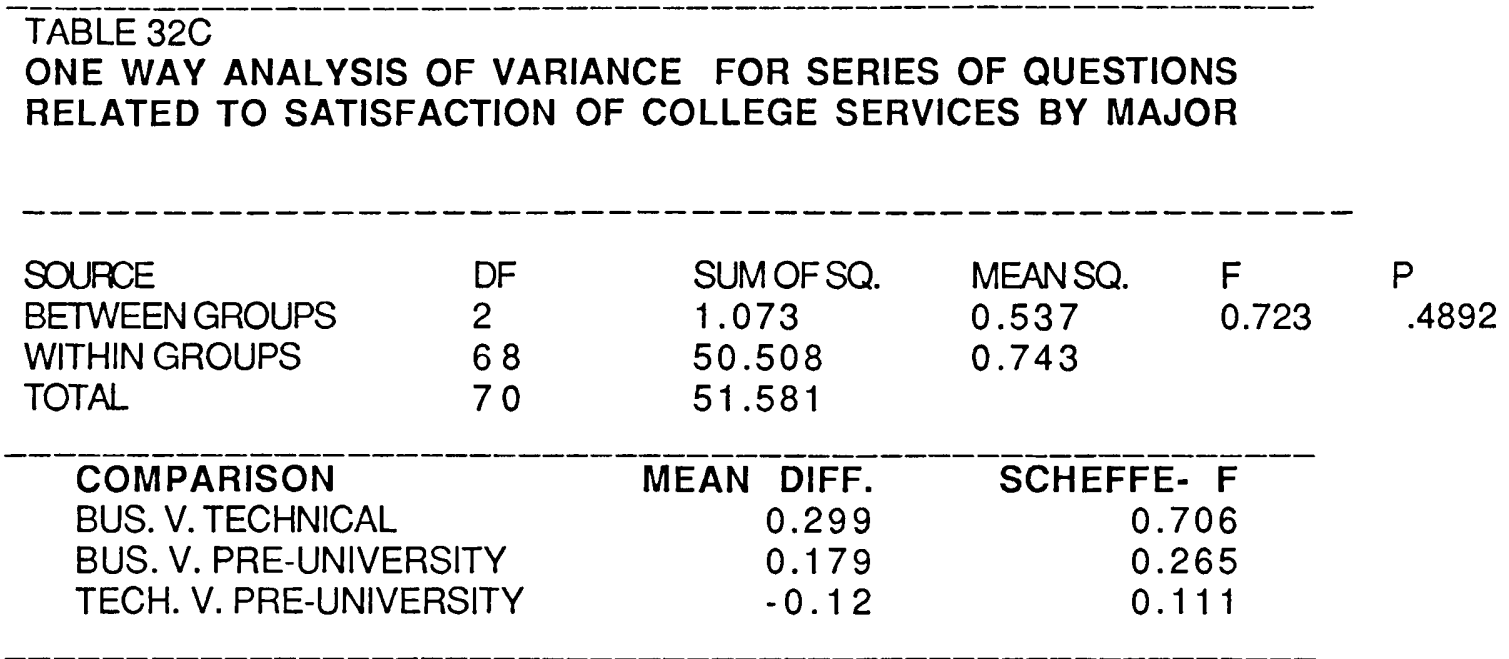

$\bar{T} \bar{A} \overline{B L E} \overline{3} \overline{2} \bar{D}$

ONE WAY ANALYSIS OF VARIANCE FOR SERIES OF QUESTIONS

RELATED TO SATISFACTION OF CURRICULUM RELEVANCE BY

MA JOR

$\begin{array}{llllll}\text { SOURCE } & \text { DF } & \text { SUM OF SQ. } & \text { MEANSQ. } & \text { F } & \text { P } \\ \text { BETWEEN GROUPS } & 2 & 0.224 & 0.112 & 0.2050 & .8153 \\ \text { WITHIN GROUPS } & 68 & 37.25 & 0.548 & & \\ \text { TOTAL } & 70 & 37.474 & & & \end{array}$

\begin{tabular}{lrl} 
& & \\
COMPARISON & -0.117 & 0.146 \\
BUS. V. TECHNICAL & 8.667 & 8.395 \\
BUS. V. PRE-UNIVERSITY & 0.126 & 0.166 \\
\hline
\end{tabular}


majors, ages, races, and national backgrounds. Their responses were as varied as the population, with both positive and negative experiences and perceptions expressed. The data served to enhance concepts, perceptions and contribute to depth of understanding. This analysis showed how students comprehended their experience at the community college in details not able to be supplied via statistical information. Qualitative data also supplied its own analysis of this study from the view of the students themselves. This phenomenological approach helped to attain a more balanced and relevant research study by complementing the quantitative data. The quantitative data resulted in no significant differences between the variables that may have influenced student perceptions. Therefore, all four null hypotheses were accepted. 


\section{Chapter V}

\section{SUMMARY, FINDINGS, CONCLUSION AND RECOMMENDATIONS}

\section{SUMMARY}

The number of international students attending school in the United States and at community colleges in particular has increased substantially in recent decades. This has resulted in an increasing number of problems to contend with for both colleges and students. The students' problems center around adjustment to a new environment, and the learning of skills and knowledge needed by the students when they return to their home countries. Consequently, international students have demanded services and curriculum relevant to both their personal and career aspirations as well as national needs. It also has resulted in demands upon the resources of institutions in serving international students. In practical remedies this has meant a more international and relevant college curriculum. The purpose of this study was to outline the trends in institutions of higher education, especially the community college, in providing program services and a curriculum relevant for foreign students. More specifically, the purpose was to qualitatively and quantitatively determined the level of satisfaction foreign students perceived that the community college has met their personal and career needs. 
The review of the literature described the international student population and outlined trends in institutions of higher education, especially the community college, in providing program services and a curriculum relevant for foreign students. The Institution of International Education Open Doors study (Zikopolous, 1991) reported a yearly rise in the number of foreign students of 5.3\%. In 1990386,900 foreign students attended U. S. colleges and universities as compared to 407,500 in 1991. The largest proportion of foreign students attended schools in the WestSouthwest region headed by California. There was a sharp increase in the Southeast, especially in Florida. Though Florida ranked 5 th in the total number of foreign students, Miami-Dade Community College led in enrollment totals of all American colleges and universities with an enrollment of over 5,757 from 125 countries (Zikopoulos, 1991: 46). Academic majors for university and community college foreign students are similar to domestic student choices. There is a common interest in business, engineering and computer sciences. In addition, more foreign students are preparing for a world of international business and telecommunications with the increased interest in mathematics/computer science and business management.

In general, students at foreign universities have reported material (eg. housing, finances) and personal services (eg. counsel, advisement) for coping as satisfactory. Klineberg and Hull (1979) reported that the gravest problems deal with housing, social contact and discrimination. Few actually desire to remain in the 
host nation and most prefer to return home. In the United States, however, students maintain that their problems center around finances, social adjustment and academic difficulties (Omar, 1986). In a national survey of 2000 foreign students from developing nations, Lee (1981) sought out foreign student perceptions of importance and levels of satisfaction in meeting personal and academic needs. Lee itemized student adjustment problems but also focused upon the relevance of their American education. She classified needs into needs for information, the degree program and program relevance. Needs for information revolved around information on American culture, community, health and housing services. The students were also concerned with information on procedures and regulations for immigration, registration and course requirements. Needs related to the degree program concerned the roles of advisors and professors. Were advisors and faculty available for planning and consultation? Was there contact with faculty having international experience? Needs related to relevance of the U. S. degree program concerned students' future jobs. Were they being prepared to assume a role as leader and change agent? Did the program address needs of the home country? Could students apply the learned technology upon returning home? Finally, were there opportunities of dealing with problems of development through seminar and faculty exchanges? (Table 4)

Related studies have indicated foreign student concerns with personal and academic needs (Boyer and Sedlacek, 1987). In relation to counseling and advisement, international students have a broad 
range of concerns. They deal with educational and vocational, emotional and social and academic issues. NAFSA (1988) has outlined professional roles and responsibilities in meeting personal and academic needs of international students. This may include supplying informtion on immigration rules, regulations, housing and health services, advising on financial and visa problems, conducting orientation and intercultural programs and fulfilling a liason role. As a liason and representative for students, advisors promote relationships between foreign students and other students, faculty and staff.

The increasing enrollment of foreign students in the United States serves as a resource for the international education curriculum. The dimensions of international education encompass a variety of activities and programs dealing with technical assistance, cultural exchanges, language and area studies, and transnational institutional relationships. Trends appear to emphasize the parameters of foreign language and area studies, global education, multicultural education, cultural exchange, technical assistance and development education (Spalding, 1982).

Options in international education include those characteristics regarded positive to any set of curriculum. Successful curriculum programs have generally included those that are flexible, allow for individualized study, and show a relationship to both student aspirations and program objectives. Curriculum would then include: 1 . core courses; 2 . courses for individuality and flexibility; 3 . skills courses; and 4 . integrative experiences 
(Dressel, 1980: 242). Thus, if the curriculum of any college is to internationalize, it would do so within the above structural framework.

Assessing needs of international students is a prime issue in determining appropriate programs and curriculum. A second issue concerns colleges recruiting and admitting students interested in the program of studies which they offer. Patrick (1983), in a comparative study of admissions procedures for foreign students, suggested that the institutions' capabilities to meet foreign student needs helped determine the level of satisfaction of relevance in education. A third issue for curriculum relevance centers around the context of a student's home country's cultural, economic and political institutions. In other words, is the acquisition of professional competencies and leadership skills in keeping with the needs of a particular developing nation? Britenbach (1970) suggested that a student's return home can determine the value and relevance of study in another country. Relevance then concerns not only content of skills and knowledge in the curriculum but also the utilization of that content. A fourth issue of relevance effects the decision of whether or not to remain in the United States. The issue of relevance, or lack of relevance may in fact influence student decisions to stay after their American education is completed. A final issue relates to the programs and solutions adopted by American colleges in developing a relevant curriculum.

As the above parameters serve to reinforce each other toward an international curriculum, the attempt to create relevancy 
requires a certain institutional emphasis (Thompson, 1976; I. I. E., 1979). For example, Florida community colleges have been in the forefront of that institutional emphasis by participating in successful consortia programs (McClean, 1990; Greene, 1990; King, 1990). Community colleges have also established two year college programs abroad. Broward Community College in particular has campuses in Europe (Seville, Marbella, Madrid, and Athens) and the Pacific rim (Malaysia and Singapore). Meeting the goals of international education in the community college also involves implementation of strategies at the classroom level (Edwards, 1990: 17-26). This may include instructional strategies meeting needs of diverse cultural groups and providing perspectives beyond a Eurocentric approach.

Community colleges have been playing an increasingly significant role in this trend toward international education (Yarrington, 1978; Fersh, 1986; Greene, 1984; Edward, 1990; Scanlon, 1990; Gleazer, 1989; Adams, 1982). It was in the 1980's that a widespread recognition of the significant role of the community college in international education came into existence. The parameters of international education became even more necessary when considering the impact of the international economy on local communities (Scanlon, 1990: 5-16). Florida has become a nationwide leader in foreign student enrollment and in developing international education in American community colleges. The focus of this dissertation was Miami-Dade Community College which leads the nation in the enrollment of foreign students. A sample of 
students from four developing nations at the North Campus, having a campus-wide and nation-wide representation, was selected to qualitatively and quantitatively determine the level of satisfaction regarding program services offered and curriculum relevance.

The method of research for this study was an "ex post facto" study or as Barnes describes it, an "after only study without controls" (Barnes, 1964: 65). Gay (1987: 247) explains ex post facto research as a type of descriptive research and refers to it as the causal-comparative method. It was expected that a causal relationship existed between both the foreign student's courtry of origin and major and his/her percieved level of satisfaction with program services and relevance of the curriculum offered at the community college. This study was both descriptive and exploratory utilizing data collection methods of group interviews, an open ended questionnaire, in depth personal interviews and a seven point Likert scaled survey questionnaire. Statistical techniques were used to analyze quantitative data from the survey and supplemented by qualitative data from the interviews and open ended questionnaire. Respondents in this study were those selected $\mathrm{F} 1$ Visa students from three nations of the Caribbean Basin (Bahamas, Columbia and Haiti) and one from Asia (Pakistan) that attend Miami-Dade Community College, North Campus. Each of the methods, qualitative and quantitative, served as validating purposes to further assess the accuracy of perceptions on the level of student satisfaction. The rationale for this study included meeting needs of individual students, reassessing institutional services and curriculum, and 
determining the role of community colleges in international development. A discussion of the findings and answer to the specific research questions are presented in the next section.

\section{FINDINGS}

Outlined in this section are the major descriptive characteristics of the sample and major perceptions of the study population. Also presented are a discussion of the findings and answers to the specific research questions.

1. 71 out of 175 students from four nations responded to qualitative and quantitative inquiries. Most of the students responding were male, 18-25, and single.

2. The Bahamas represented the country with the largest number of respondents, 23 of 71 or $32.4 \%$. Business represented the major with the largest number of respondents, 25 of 71 or $35.2 \%$. 57 out of 71 indicated the possibility of remaining in the $U$. S. due to the home social and political situation.

3. Students expressed a variety of both satisfactory and unsatisfactory perceptions with progam services at Miami-Dade Community College, North. However, the qualitative approach revealed students were unsatisfied with the delivery of College services. Complaints centered around the lack of available staff, the impersonal nature of the North Campus, and a bureaucracy perceived as cumbersome. 
4. Overall, students were satisfied with many aspects of the relevance of the curriculum. Both quantitative and qualitative research revealed positive attitudes toward this aspect of their experience at Miami-Dade Community College, North.

5. Specifically, students had expressed the opportunity to hear international perspectives and present perspectives from their home countries in class. They indicated that teachers were receptive to foreign student input on global issues and were appreciative of the level of technology learned.

6. There was no significant difference between country of origin and perceived levels of satisfaction with program services or relevance of the curriculum. However, specific items of the survey questionnaire revealed significant differences. Pakistanis, Haitians and Columbians differed in their perceptions of exchange of visiting professors, opportunity to assess academic and personal career needs with counselors and advisors, and availability of information and procedures in planning the college program.

7. There was no significant difference between major programs of study and their perceived level of satisfaction with program services or relevance of the curriculum, nor were there significant differences on any questionnaire items.

Through these findings, answers to the five research questions posed in Chapter I are presented.

The first research question was, "What is the level of satisfaction foreign students have regarding program services offered by the community college?" The responding 71 
international students were undecided on this question. The mean for all students on a scale of 1 (very satisfied) to 7 (very unsatisfied) was 4.04. The scores for each of the six items in the questionnaire ranged from 3.521, Availability of Information and Procedures in Planning the College Program, to 4.817, Community and Health Services Available to Foreign Students and Families. In the table Availability of Information and Procedures in Planning the College Program, scores were between satisfied to undecided. For Community and Health Services Available to Foreign Students and Families, scores were closer to unsatisfied.

The information gathered through qualitative research presented a range of answers pertaining to this question. Students expressed needs and frustrations not unlike the findings of Klineberg (1979), Lee (1981) and Boyer (1987). Many were critical of college delivery of services while others believed it was the student responsibility to seek out that information. Some points of contention were competency of advisors, availability of counselors and receiving credit for work done outside the United States. In all, students expressed a variety of both satisfactory and unsatisfactory perceptions, but the qualitative approach revealed students were unsatisfied with the delivery of service progams.

The second research question was, "How satisfied are foreign students with the relevance of the community college curriculum?" From the statistical tables, the responding 71 international students were again undecided on this question. The mean for all students was 3.625. This corresponds to between 
satisfied but closer to undecided on the 7 point scale. The scores for each of the ten items in the questionnaire ranged from 2.761, College Curriculum Relevant to Your Future Job in Your Country, to 4.634, The Exchange of Visiting Professors Between Universities of Your Country and This College. In the table College Curriculum Relevant to Your Future Job in Your Country, scores were between satisfied to quite satisfied. For the table The Exchange of Visiting Professors Between Universities of Your Country and This College, scores were between undecided and unsatisfied. Other items of satisfaction were Level of Technology Applicable to the Future of Your Country, and Curriculum Including Training to Introduce Changes and Curriculum Including Training for a Leadership Role.

The information gathered through qualitative research again presented a range of answers pertaining to this question. Similar to Meyer (1979) students believed their U. S. education was useful and practical. Their training and technical learning were mid-level skills commensurate with national needs. Such mid-level skills are mostly in the areas of engineering, data analysis, tourism and business management which are appropriate to national development and these students' major progams of study. Many were happy with the curriculum and specific courses of their major while others believed humanities and courses outside their major were irrelevant. Qualitatively, most answered positively to this research question. Overall, students were satisfied with many aspects of the relevance of the curriculum. 
The third research question was "Which specific aspects of the international education curriculum do foreign students perceive as relevant?" This question is best answered through the qualitative methodology of group and personal interviews and open ended questionnaire. On a number of occasions, students had expressed the opportunity to present perspectives from their home countries in class. They remarked that teachers were receptive to foreign student input on global issues. One Pakistani student expressed the non western perspectives included in courses as well as acknowledgement of training for change and leadership. These skills were thus recognized as a relevant component of courses offered. The multicultural climate at Miami-Dade was also acknowledged and appreciated. The literature review included these as as components of international education (Burn, 1980: 73). Statistically, the items with more positive scores, College Curriculum Relevant to Your Future Job in Your Country, and Applicable Level of Technology are especially noted here. Students did not discuss experiences with technical assistance and consortium programs at this college. The review of the literature explained this aspect of international education as practiced at other community colleges in the U. S. and Florida (McClean, 1990; Greene, 1990). Finally, none of the students were aware of the exchange of professors between universities of their country and Miami-Dade, though there are faculty from other countries present. Only the older, more mature Haitian student interviewed appeared aware of any institutional role of Miami-Dade in international 
education. It was apparent that some of the college's efforts toward international education went unnoticed by this group. This may be due to their relatively young age and immediate personal concerns rather than institutional academic issues.

The fourth research question was "Is there a relation between the foreign student country of origin and level of satisfaction with program services and curriculum relevance?" Bahamian students were undecided with regard to both services and curriculum relevance. They were most satisfied with the effort of the community college in providing a curriculum relevant to their future job, relevant to the needs of their country and a level of technology applicable to the future of their country. They were unsatisfied with the availability of community and health services and receiving credit for work done outside the United States. Some Bahamian students complained of the impersonality experienced on the North campus, while others appreciated the opportunity to work in Miami and relevancy of business courses.

Colombian students' level of satisfaction with services and curriculum relevance was undecided, 3.823, but expressed extremes of satisfaction and dissatisfaction. Colombians registered close to the level of satisfied on most of the ten questions pertaining to curriculum relevance. They were especially satisfied with the applicable technology, a curriculum relevant to their future job and availability of information and procedures in planning the college program. They were not satisfied with community and health services and receiving credit for work done outside the $U$. $S$. 
Interviews revealed a mixture of perceptions on these issues. In specific instances, some were highly critical of the limited functions of the international student office while others thought the student survival course very helpful. While some students were satisfied with life in Miami and the role played by the international student office the student interviewed was bitter with his experiences in America and the services offered at this college.

Haitians registered scores closest to the level of 3 which represents satisfied. This national group was more satisfied with program services (3.769) and relevant curriculum (3.467) than the other groups. Though there is no significant difference in neither of the series of questions, their interviews were the most positive. Both visa and non visa Haitians are a part of this community and have a stake in it. They were mostly critical of community and health services. They complained of inadequate housing and access to health care. This group was consistent in all other categories and believed their courses would be perceived relevant if they went back home, but political and social conditions there made them reconsider returning.

In contrast to the Haitians, Pakistanis were highly critical of Miami-Dade Community College, North in the area of program services. Of the entire sample, they registered a mean of 4.5 which is the closest to the level of 5, unsatisfied. Interviews revealed that many were frustrated by the bureaucracy and its effects on having the opportunity to assess academic and personal career needs with advisors and counselors, and planning their 
program at Miami-Dade Community College. However, the international content of the curriculum was recognized. Nevertheless, they even perceived the relevance of the curriculum as unsatisfied. International materials in courses, seminars on national development and exchange of professors received particularly high scores $(4.857,4.929$ and 5.429, respectively). Many believed professors were not aware of the social and economic situation facing Pakistan. The literature review alluded this issue of curriculum relevance. It centered around the context of a student's home country's cultural, economic and political institutions. Is the acquisition of professional competencies and leadership skills in keeping with the needs of a particular developing nation? Britenbach (1970) suggested a student's return home can determine the value and relevance of study in another country. Thus, there is relevance in education when training relates to the environment of the student's country. Similarly, the Rawls and Akapanudo (1981) study recommended more effective educational and career counseling as well as matching educational programs to a student's home country's development needs. Like the others, most intended to remain in the $U$. S. as a country of preference, but this may also be motivated by a perception of a curriculum not relevant to their country's needs.

The fifth research question was "Do students' perceptions of satisfaction with program services and curriiculum relevance relate to the major area of academic or vocational training?" Majors were grouped into three categories since the numbers were not sufficient 
for statistical analysis. Again there was no significant difference between major programs of study and perceived level of satisfaction with program services or relevance of the curriculum, nor were there significant differences on any questionnaire items. All majors were dissatisfied with community and health services , and the exchange of professors. Items of curriculum relevance to their future job and applicable technology received responses that indicated the most satisfaction. Business administration, engineering and education majors appeared most satisfied when considering group interview responses. The information gathered through qualitative research again revealed a range of answers pertaining to this question, but mostly positive. Many believed their American education was useful and practical. Meyer (1979) alluded to particular majors more satisfied with the relevance of the American college curriculum. Their training and technical learning were at mid-level skills and appropriate to national development needs. Such mid-level skills are mostly in the areas of engineering, data analysis, tourism and business management. Similarly, 37 of 71 students sampled in this study indicated the above majors. Many were happy with the curriculum and specific courses of their major while others considered humanities courses and courses outside their major as irrelevant. 


\section{CONCLUSIONS}

Conclusions drawn are based on the findings and assumptions stated. Overall, students were not satisfied with the delivery of program services of Miami-Dade Community College, North. The impersonal nature of the campus was the characteristic most frequently mentioned. Many students proposed the need for a more residential environment and the availability of dormitories. This would serve housing, health and adjustment needs. Attitudes observed and perceived of staff and American students by international students suggest racial and cultural conflicts and an environment unlike the healthy multicultural diversity espoused. Lack of information provided and availability of counselors and advisors questions the accurate assessment of foreign student needs and the accommodation of those needs by Miami-Dade Community College, North. Also inferred from their experience with counselor and advisors is an insensitivity to the international student population. Finally, many were bitter of the fact of higher tuition rates and not receiving credit for work done outside the United States. Overall they felt being taken advantage of, and questioned the sincerity of this college in serving their needs.

International students surveyed did express some satisfaction with the relevance of certain aspects of the curriculum. The curriculum, international perspectives, level of technology and training for changes and leadership were all viewed relevant to 
individual, career and country needs. Individual teachers were receptive to student input on international perspectives and many did include non western perspectives as part of course content. However, nowhere was this acknowledged as part of an institutional effort toward an international curriculum. The developments in international education by local universities may have influenced individual instructor efforts. However, the role of Miami-Dade Community College to deliberately incorporate international education as part of a campus-wide or college-wide curriculum was not in evidence. Contact with international governmental organizations and the exchange of professors from other countries are additional ingredients of institutional approaches toward curriculum relevance and international education. To the extent that this exists was not made apparent to the international students surveyed.

In conclusion, the public relations message of Miami-Dade Community College, North does not match the perceptions held by a segment of the population this college intends to serve, its international students. Whether it is the cumbersome bureaucracy, insensitivity toward multicultural populations, less than professional behaviors and attitudes held by clerical and service staff, or lack of an institutional effort toward international education, the existence of a credibility gap is all too evident. 


\section{IMPLICATIONS}

The results of this study have implications for those community colleges with large numbers of international students with sensitivity to the issues related to their education. Students from other nations are their future leaders of their countries and hopefully can play a positive role in relations between the two countries. Their perception of the value of their education and experiences in America is significant for this future potential relationship. Individual, institutional and global issuses need to be considered. Community colleges consider individual issues by providing services and programs easing student adjustment to life at the college and in the community. They provide services to meet social, cultural and psychological needs of students and enhancing the relationship of foreign students to faculty, other students and the community.

Curriculum should be designed so as to meet individual and career aspirations and needs of the student home country. Increased perceptions of satisfaction will enhance both international relations and future enrollments at the institution. The community college has a responsibility in determining that level of satisfaction in order to improve and promote program effectiveness. The delivery of services such as progam advising and counseling, the atmosphere of multiculturalism, and the consideration of an international education are components of that 
program. If a community college education is perceived relevant to the needs of a developing country, it is also keeping abreast of international and global issues. For Miami-Dade this is especially so as it pertains to students from nearby Caribbean Basin nations and to traditional attendants from other parts of the world.

Specific implications for community colleges with a foreign student contingency is the reassessment of the international curriculum currently in existence. A major premise of this study was that the growth of international education in American universities and community colleges reflects the growing enrollment of foreign students. It was also noted that options in international education include those characteristics regarded positive to any set of curriculum. Thus, some implications for the community college curriculum arising from this research are the following:

1. Core courses should recognize the interdependence among nations and appreciation of non western social and political perspectives.

2. Students should have the oppportunity and flexibility to confront global issues from perspectives of internationalism and interdependency.

3. Integrative experiences should include the opportunities for cultural exchange and to study abroad.

4. Institutions should be involved with college consortia, faculty inservice programs in multicultural and international issues, and collaborative projects with international agencies. 
5. The components of the leadership and training skills imparted should include contact with international organizations as opposed to solely domestic agencies.

6. The appropriateness of these skills to the home country is another important implication. Investment benefits should be assured by determining if there are jobs in the home country for which to be trained. There needs to be an influence upon another nation's development through an American education.

Understood but not directly expressed for community college program services offered is the development of multicultural competencies and sensitivities of staff. Thus, some implications for community college services arising from this research are the following:

1. Services should effectively deal with student cultural and adjustment problems in a new developed country, often drastically different from an undeveloped country.

2. Information on community, health and academic services should be provided.

3. Both counselors and advisors should be available and sensitive to foreign student perceptions and perspectives on individual or social issues.

4. Faculty members should devote time to the academic interests, needs and perspectives of foreign students.

5. Staff should promote interaction between foreign students, American students, faculty and community. 
6. Finally, there should be institutional arrangements for academic work completed outside the United States.

\section{LIMITATIONS OF THE STUDY}

In the following parapraphs, the assumptions undergirding the study are restated, followed by discussions. Assumption 1 states that the sample of students from each country reflects the student population of that country at the college. Each of the populations of foreign students sampled does have a national representation. However, given the return rate of 71 out of 175, it would be inconclusive that the results are generalizable either college-wide or nation-wide. The small sample of the North Campus may limit the results and generalizability. This is more descriptive of a case study in that though the sample does represent ethnic and racial categories of Miami-Dade Community College, a larger sample of students and perhaps from other community colleges may be needed. In addition, this writer realizes that a few of the Pakistani students, for example, who did not participate were diametrically opposed ideologically to those who did participate. This might have had an effect on overall perceptions presented by that group. A larger sample could overcome this. In all, the conditions experienced by foreign students, the hesitancy to devulge personal information (eg. working illegally), and reluctance to participate in 
a questionnaire study may limit involvement and thus generalizability.

Assumption 2 states that foreign students are aware of the socio-economic needs of their country. Previous studies (Ekpe, 1980; Rowland, 1990; Timko, 1990) surveyed opinions of foreign graduate students. Graduate students have more awareness than freshmen or sophomores of the developmental needs of a nation. This dissertaion focused on first and second year community college students. Descriptive statistics indicated a young student population, or $76.1 \%$ in the $18-25$ age bracket who probably have even less awareness than graduate students.

These statistics also indicated that 57 of 71 believed it possible to remain in the U.S. Many would not return to their home countries to contribute to national development. Assumption 3 states that they will return to their country to contribute to their country's development. Assumption 4 states that they represented future leaders and change agents in their countries. While many perceive themselves in such a future role, the high percentage of students considering remaining in the $U$. S. limits accurate inferences on relevant items. Both the survey instrument and open ended questionnaire inquired into their perception of the curriculum that included training to introduce changes and leadership role in their home country.

Another limitation is the accurate perception of relevance while students at Miami-Dade Community College, North. Assumptions 5 and 6 alluded to the problem of applying skills 
learned to their home country. Relevance is best realized after applying the skills learned in the U.S. to the home country situation. Follow up studies of alumni who return home would shed more light on this issue.

\section{SUGGESTIONS FOR FUTURE RESEARCH}

This study focused on international students at Miami-Dade Community College, North Campus and differed from previous studies on curriculum relevance with their focus on graduate students. The study results, based on an undergraduate population and the use of both qualitative and quantitative techniques gives rise to suggestions and recommendations for future research.

1. Repeat the study with a larger sample size to enhance external and internal validity. This may include the other four campuses at Miami-Dade Community College, or other community college campuses in Florida.

2. Repeat the study with groups of foreign students representing other nations besides the four from this study. International students at Miami-Dade are represented by 137 nations. Note also that foreign students prefer personal contact and are not likely to respond to impersonal quantitative research methods. Qualitative research has siginificantly contributed to the depth of analysis of this study given the complexity and number of issues affecting perceptions. 
3. Apply the methodology employed through longitudinal studies of those students who have returned to their home country. This would more accurately depict the perception of relevance of the curriculum. Maliyamkono, Ishumi and Wells (1982) for example, conducted a study on the impact of foreign study on development in East Africa. They concluded that there is relevance in education when training relates to the environment of the student's country. Likewise, Rawls and Akpanudo (1981) recommended matching educational programs to students' home countries' development needs.

4. Compare the perceptions of the level of satisfaction of program services and relevance of the curriculum with international students from developing countries and developed countries. Culture, class and socio-economic variables are powerful determinants of perception. Issues of degree of culture conflict, country needs and student background vary greatly between developed and developing nations. From which countries can Miami-Dade Community College best meet individual, career and national needs?

5. Evaluate services and curriculum relevance from perspectives of faculty and administration. Which needs do they believe are necessary and are being met? Do they match the philosophy and goals of the community college? 


\section{BIBLIOGRAPHY}

Adams, H. A. and Earwood, G. (1982). Internationalizing the Community College. ISHE Fellows Program, Research Report No.

2. Tallahassee, Florida: Institute for Studies in Higher

Education. (ERIC Document Reproduction Services No. ED 225638)

Altbach, P. G. et. al (1985). Research on Foreign Students and International Study: An Overview and Bibliography. New York: Praeger.

Barnes, F. P. (1964). Research for the Practitioner in Education. Arlington, Virginia: National Association of Elementary School Principals.

Baldwin, A. (1991). International Student Profile. (Research Report No. 91-11R). Miami, Fl.: Miami-Dade Community College, Office of Institutional Research.

Berger, P. L. et. al. (1973). The Homeless Mind: Modernization and Consciousness. New York: Random House.

Bogdan, R. C. and Biklen, S. K. (1982). Qualitative Research for Education: An Introduction to Theory and Methods. Boston: Allyn and Bacon, Inc.

Boyer, S. P. and Sedlacek, W. E. (1987). Attitudes and Perceptions of Incoming International Students. College Park, Maryland: University of Maryland Counseling Center. (ERIC Document Reproduction Services No. ED 278936)

Breitenbach, D. (1970). "The Evaluation of Study Abroad." in I. Eide ed.). Students as Links Between Cultures. Paris: UNESCO. pp. 70-98.

Burn, B. B. (1980). Expanding the International Dimension of Higher Education. San Francisco: Jossey-Bass Publishers. 
Casse, P. (1979). Training for the Cross Cultural Mind. Washington, D.C.: $\quad$ Society for Intercultural Training, Education and Research.

Davis, F. J. (1973). "Problems of Development in Turkey as Seen by Turks Returned Home from Study in American Universities." Sociology and Social Research. 57, no. 4, pp. 429-442.

Dressel, P. (1980). Improving Degree Programs: A Guide to Curriculum Development, Administration and Review. San Francisco: Jossey- Bass Publishers.

Edwards, J. and Tonkin, H. R. (Summer, 1990). "Internationalizing the Community College: Strategies for the Classroom." New Directions for Community Colleges. pp. 17-26.

Eide, I., ed. (1970). Students as Links Between Cultures. Paris: UNESCO.

Ekpe, C. P. (1980). The Reactions of Foreign Students to Their Iraining in the United States. Ph. D. Dissertation, University of Pittsburgh.

Fersh, S. and Fitchen, E. (1986). The Community College and International Education. Cocoa, Florida: Brevard Community College.

Fry, G. W. (1984). "The Economic and Political Impact of Study Abroad." Comparative Education Review. 28, no. 2 pp. 203220.

Galder, N. (1967). "International Relations and Exchanges in Scientific and Technical Fields." in UNESCO Handbook of International Exchanges. Paris: UNESCO. pp. 29-37.

Gay, L. R. (1987). Educational Research: Competencies for Analysis and Application. Columbus, Ohio: Merrill Publishing Co.

Gleazer, E. J. (1989). "Initiatives in International Education." in T. O'Bannion. (Ed.). Innovation in the Community College. Washington, D. C.: Macmillan. 
Goodwin, C. D. and Nacht, M. (1983). Absence of Decision: Foreign Students in American Colleges and Universities. New York: Institute of International Education.

Greene, W. E. (Dec./Jan., 1984-85). "Area 8:

TheInternational/InterculturalGeneralEducationRequirement." Community. Technical and Junior College Journal. pp. 18-23.

Greene, W. E. (Aug./Sept., 1990). "Establishing American Colleges Abroad." American Association of Community and Junior College Journal. pp. 12-16.

Gregorc, A. F. (1986). An Adult's Guide to Style. New York: Gabriel Systems.

Hoeck, J. and MacDougall, P. R. (1982). An Assessment of the Involvement of the LACCD in Contract Education for Foreign Students. Los Angeles: Los Angeles Community College District. (ERIC Document Reproduction Service No. ED 214603)

Hoover, K. (1980). College Teaching Today: A Handbook for Post Secondary Instruction. Boston: Allyn and Bacon, Inc.

International Education Advisory Council (1987). Strategic Plan for International Education in the Maricopa Community Colleges. Paper presented at the National Association of Foreign Student Affairs convention. June, 1989. Minneapolis, Minnesota.

Institute of International Education (I. I. E.) (1979). National Development Through International Education. New York: Author. (ERIC Document Reproduction Service No. ED 1 71174)

International Education Institute. (1991). Global Perspectives. Fort Lauderdale, Florida: Broward Community College. v. 14, no. 1.

Jenkins, H. M., Ed. (1983). Educating Students from Other Nations: American Colleges and Universities in International Educational Exchange. San Francisco: Jossey Bass. 
Jenkins, H. M. (1980). The Relevance of U.S. Education to Students from Developing Countries. Washington, D. C.: National Association for Foreign Student Affairs. (ERIC Document Reproduction Service No. ED 197672)

King, M. (Summer 1990). "Foreign Technical Assistance Programs." New Directions for Community Colleges. pp. 77-85.

Klineberg, O. and Hull, W. F. (1979). At a Foreign University: An International Study of Adaptation and Coping. New York: Praeger Publishers.

Lee, M. Y., Abd-Ella, M. and Burks, L. A. (1981). Needs of Foreign Students from Developing Nations at U.S. Colleges and Universities. Washington, D. C.: National Association of Foreign Student Affairs.

Lee, M. Y. and Ray, M C. (1987). "Return Intentions of Students from Four Developing Countries." International Review of Education. vol. 33 , no. $1, \mathrm{pp} .75-85$.

Lofland, J. and Lofland, L. H. (1984). Analyzing Social Settings: A Guide to Observation and Analysis. Belmont, Ca.: Wadsworth, Inc.

McClean, J. (Summer, 1990). "Consortial Approaches to International Education." New Directions for Community Colleges. pp. 4756.

Maliyamkono, T. L., A. G. M. Ishumi and S. J. Wells. (1982). Higher Education and Development in Eastern Africa. London:

Heinemann Educational Books, Inc.

Meleis, A. I. (July, 1982). "Arab Students in Western Universities: Social Properties and Dilemmas." Journal of Higher Education. pp. 439- 447.

Miami-Dade Community College (1991). "Facts in Brief." (Mimeographed.) 
Miami-Dade Community College Catalog, 1991-1992. Miami: MiamiDade Community College, pp. 5-6.

Moock, J. L. 1984. "Overseas Training and National Development Objectives in Sub-Saharan Africa." Comparative Education Review. 28, no. 2, pp. 221-240.

Morris, C. (1992). Fall Student Profile: 1991-92 Closing Fall Enrollment Analysis. Miami: Miami-Dade Community College Office of Institutional Research.

Myer, R. B. (1979). "Summary of Pre-Conference Planning and Research." in M. L. Taylor (ed.). Curriculum: U.S. Capacities. Developing Countries Needs. NewYork: Institute of International Education. pp. 7-17.

Myers, I. B. (1962). Manual: The Myers-Briggs Type Indicator. Princeton, New Jersey: Educational Testing Service.

National Association of Foreign Student Affairs [NAFSA] (1988). The Profession of Foreign Student Advising. Washington, D. C.: author.

Ogunbi, A. J. 1978. The Perceived Relevance of Foreign Student's Training to Their Role as Future Change Agents in National Development. Ph. D. Dissertation, Michigan State University.

Omar, A. A. (1985). Problems of International Students as Perceived by International Students and Faculty in a Public University." Ph. D. Dissertation, University of North Texas.

Patrick, W. S. (1983). "Developing Effective Selection Practices." in H.M. Jenkins (Ed.). Educating Students from Other Nations.

San Francisco: Jossey Bass, pp. 135-162.

Pusch, M. D., Ed. (1980). Multicultural Education: A Cross Cultural Training Approach. Chicago: Intercultural Press, Inc.

Quimbita, G. (1989). Internationalizing the Community College: Examples of Success. ERIC Clearinghouse for Junior Colleges. pp. 1-2. (ERIC Document Reproduction Service No. ED 321833) 
Rawls, J. R. and Akpanudo, M. (1981). "Training Obtained in Developed Countries and Needs of a Developing Country." International Review of Applied Psychology. 30, pp. 535552.

Rowland, P. M. (1990). Foreign Students at a U. S. School of Public Health: The Relevance of Their Learning Experience to Their Role as Change Agents in Health. Ph. D. Dissertation, University of California at Los Angeles.

Scanlon, D. C. (Summer, 1990). "Lessons from the Past in Developing International Education in Community Colleges." New Directions for Community Colleges. pp. 5-16.

Shannon, W. G. (1976). A Survey of International/Intercultural Education in Two Year Colleges. LaPlata, Md.: Charles County Community College

Simmons J., Ed. (1980). The Education Dilemma: Policy Issues for Developing Countries in the 1980's. New York: Pergamon Press.

Solmon, L. C. and Young, B. J. (1987). The Foreign Student Factor: Impact on American Higher Education. New York: Institute of International Education.

Spaulding, S. and Coehlo, G. V. (1980). "Research on Students from Abroad:The Neglected Policy Implications." In G. V. Coehlo and P. I. Ahmed (Eds.), Uprooting and Development: Dilemmas of Coping with Modernization. New York: Plenum Press.

Spaulding, S. et. al. (1982). "International Education." in Encyclopedia of Educational Research. New York: The Free Press.

Taylor, M. L., Ed. (1979). Curriculum: U. S. Capacities, Developing Countries Needs. New York: Institute of International Education. 
Timko, J. J. (1990). Educational Needs of International Graduate Students as Perceived by University of Missouri-Columbia Graduate Faculty Members. Ph. D. Dissertation, University of Missouri-Columbia.

Walton, B. J. (1967). Foreign Student Exchange in Perspective: Research on Foreign Students in the U.S. Washington, D. C.: Department of State.

Yarrington, R., Ed. (1978). Internationalizing Community Colleges. Washington, D. C.: American Association of Community and Junior Colleges.

Zikopoulos, M. (Ed.) (1990). Open Doors: 1989/90. New York: Institute of International Education.

Zikopoulos, M. (Ed.) (1991). Open Doors: 1990/91. New York: Institute of International Education. 
APPENDICES A THRU G

142 


\section{APPENDIX A}

FIGURES 1 AND 2 


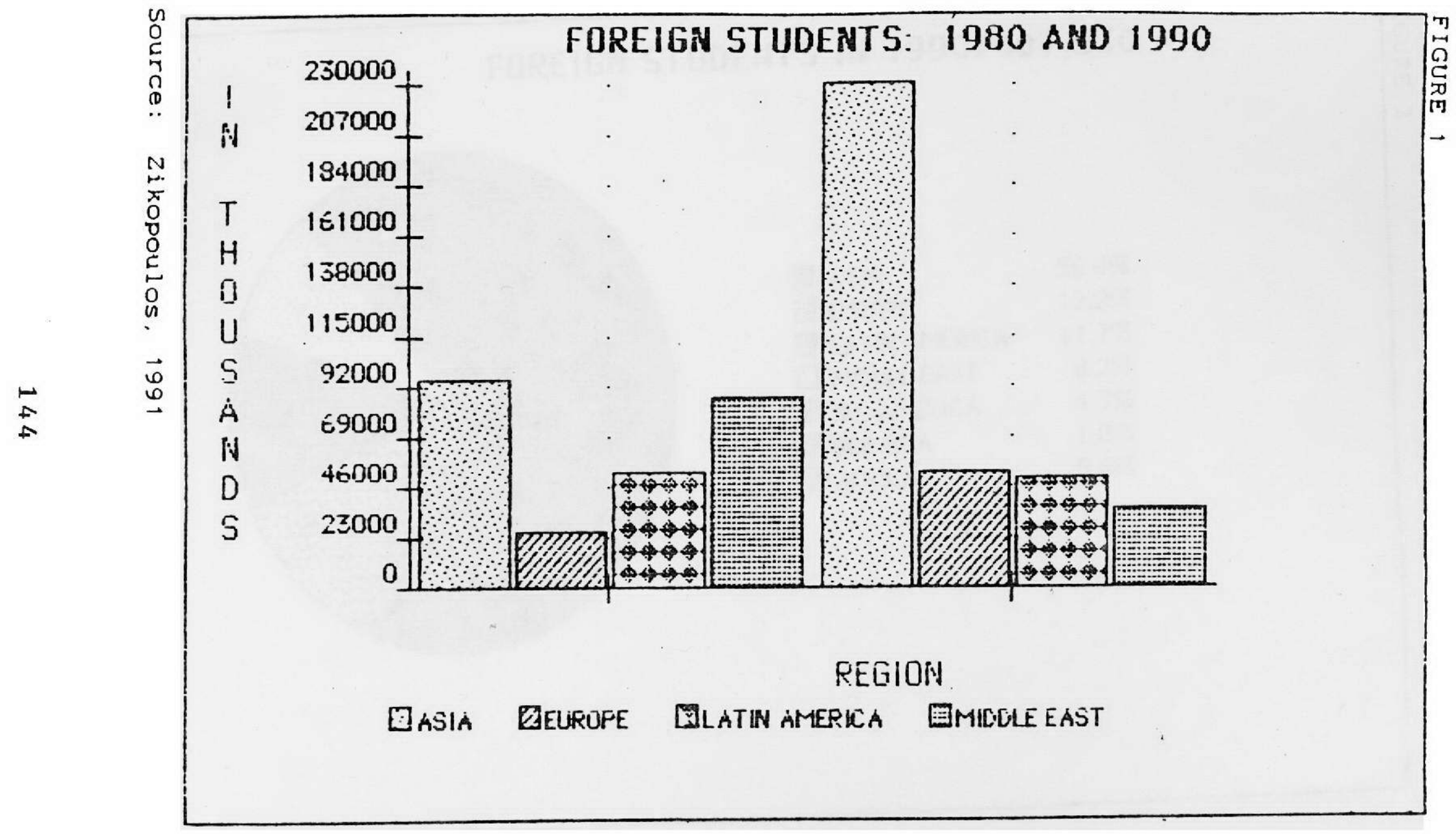




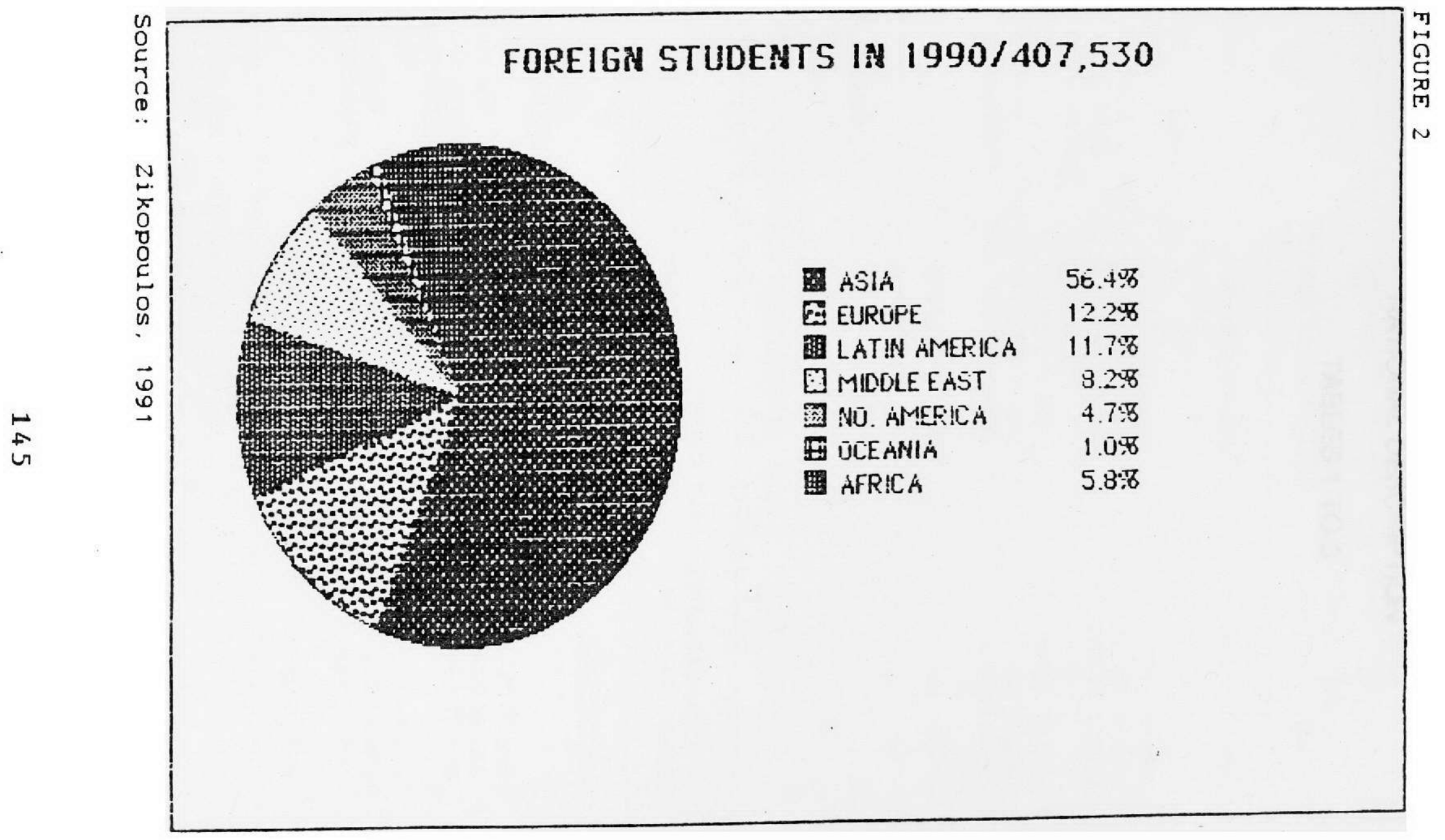


APPENDIX B

NATIONAL DESCRIPTION

TABLES 1 TO 3 
TABLE 1. OPENING FALL ENROLLMENTS, 1976

\section{OPENING FALL ENROLLMENTS \\ DOMESTIC STUDENTS FOREIGN STUDENTS}

\begin{tabular}{lrr} 
TYPEOF & NUMBER PERCENT \\
INSTITUTION & NUMBER PERCENT & \\
PUBLIC INSTITUTIONS & & \\
UNIVERSITIES & $204527118.80 \%$ & $4775421.70 \%$ \\
4-YEAR COLLEGES & $279482825.60 \%$ & $\mathbf{3 9 2 5 1 1 7 . 9 0 \%}$ \\
2-YEAR COLLEGES & $\mathbf{3 7 2 6 6 5 6 3 4 . 2 0 \%}$ & \\
PRIVATE INSTITUTIONS & & $3275414.90 \%$ \\
UNIVERSITIES & $6676156.10 \%$ & $3795217.30 \%$ \\
4-YEAR COLLEGES & $151977413.90 \%$ & $\mathbf{3 1 7 4} \mathbf{1 . 4 0 \%}$ \\
2-YEAR COLLEGES & $\mathbf{1 4 7 5 3 2 1 . 4 0 \%}$ & $219750100.00 \%$ \\
TOTALS & $10901676100.00 \%$ & \\
\hline
\end{tabular}

SOURCE: SOLMON, 1987: 44

TABLE 2. OPENING FALL ENROLLMENTS, 1982

\section{OPENING FALL ENROLLMENTS \\ DOMESTIC STUDENTS FOREIGN STUDENTS}

TYPE OF

INSTITUTION

NUMBER PERCENT

PUBLIC INSTITUTIONS

UNIVERSITIES

4-YEAR COLLEGES

2-YEAR COLLEGES

PRIVATE INSTITUTIONS

UNIVERSITIES

4-YEAR COLLEGES

2-YEAR COLLEGES

TOTALS
$208551017.00 \%$

$297725624.30 \%$

$448013636.60 \%$

$6868915.60 \%$

$176039414.40 \%$

$2661832.20 \%$

$12256370100.10 \% *$
NUMBER PER CENT

$8679226.10 \%$

$7426222.70 \%$

$5728917.20 \%$

$4429713.30 \%$

$6425219.30 \%$

$42581.30 \%$

$33215099.90 \% *$

"NOT EQUAL TO 100\% DUE TO ROUNDING ERROR

SOURCE: SOLMON, 1987: 45 
TABLE 3. PROBLEMS AND SOURCES OF DIFFICULTIES: RANK BY COUNTRY

\begin{tabular}{|c|c|c|c|c|c|c|c|c|c|c|c|}
\hline ITEM & BRAZIL & CANADA & FRANCE HONGKON & & INDIA & IRAN & JAPAN & KENYA & U. K. & U.S. & W. GERM. \\
\hline FINANCIAL PROB. & 1 & 1 & 1 & 1 & 2 & 1 & 1 & 3 & 1 & 1 & \\
\hline ILL HEALTH & & & & & 2 & & & & 4 & & 3 \\
\hline PERSONAL DEPRESSION & & 3 & 4 & & & 4 & & & 2 & 4 & \\
\hline $\begin{array}{l}\text { DIFFICULTY IN: } \\
\text { ADJUSTING TO CLIMATE }\end{array}$ & & & & & & & & & & & \\
\hline $\begin{array}{l}\text { ADJUSTING TO CLIMATE } \\
\text { ADUUSTING TO FOOD }\end{array}$ & 3 & 2 & & & 2 & & & & & 3 & \\
\hline $\begin{array}{l}\text { ADJUSTING TO FOOD } \\
\text { RELATIONS WITH THE }\end{array}$ & & & & & 1 & & & & & 3 & \\
\hline $\begin{array}{l}\text { RELATIONS WITH THE } \\
\text { OPPOSITE SEX }\end{array}$ & & & & & & & & & & & \\
\hline $\begin{array}{l}\text { OPPOSITE SEX } \\
\text { LACK OF: }\end{array}$ & & & 2 & & 2 & & & 5 & 4 & 5 & 3 \\
\hline OPOPORTUNITYTOUSE & & & & & & & & & & & \\
\hline LOCAL LANGUAGE & & 4 & 4 & & & & & 5 & & & \\
\hline DIRECTIONS IN & & & & & & & & & & & \\
\hline ACADEMICS & & & & 3 & & & 1 & & & & 3 \\
\hline PERSONAL COUNSELING & & & & & & & 3 & & & & \\
\hline CONTACT WITH & & & & & & & & & & & \\
\hline FELLOWSTUDENTS & & & & & & 5 & & & & & 3 \\
\hline MOTIVATION IN STUDIES & 3 & & & & & & & & & & 3 \\
\hline FACILITIES FOR SPORTS & 3 & & 4 & & & & & & & & \\
\hline PRIVATE PLACE TO STUDY & & & & 3 & & & 3 & 1 & & & \\
\hline INFO REGARDING PROGRESS & & & & 3 & & & & & & & \\
\hline PROB. W/EXAMS & & & 4 & & & & & & & & \\
\hline PROB. W/ADMINISTRATION & & & & & & & & & & & \\
\hline PROB. W/ PROPER PLACEM & MENT & & 4 & & & & & 2 & & & 1 \\
\hline INSUFFICIENT PREVIOUS & & & & & & & & & & & \\
\hline TRAINING & 2 & & & & & & 3 & & & & \\
\hline
\end{tabular}

(A) RANKING FROM 1 TO 5 ( $1=$ MOST TROUBLESOME)

SOURCE: KLINEBERG, 1979: 41 


\section{APPENDIXC}

ISSUES OF CURRICULUM RELEVANCE

TABLES 4 THRU 6 
Table 4 Needs Related to Relevance of the U.S. Degree, Needs for Extracurricular Professional Activities in U.S.

Relevancy of U.S. Degree Need for....
Importance Scores Satisfaction Scores

Total Mean (A)

Total Mean(B)

6.12

4.83

A program relevant to your future job in your country

6.02

4.69

A program relevant
of your country

Level of technology applicable to the future of your country

6.04

4.79

Obtaining basic knowledge in your area

6.36

5.55

of study

Having international materials included in courses

5.58

4.11

Training to apply knowledge

6.41

4.20

Training for leadership role

5.36

4.22

Training to introduce changes in your country

Thesis research in your country

4.05

Seminars with students from several departments to deal with problems of national development

Exchange of visiting professors between universities of your country and those in the U.S.

Extracurricular Professional Activities in the U.S.

Need for....

Opportunities to give information about your country in educational situation

3.65 
Opportunities to attend off-campus returning home
A. $1=$ very important
2 = quite important
$5=$ somewhat important
$3=$ somewhat important
$4=$ neither unimportant nor important
$6=$ quite important
$7=$ very important
B. $1=$ very unsatisfied
$5=$ somewhat satisfied
2 = quite unsatsified
$6=$ quite satisfied
$3=$ somewhat unsatisfied
$7=$ very satsified
$4=$ neither unsatisfied nor satisfied

Source: Lee, 1981: 66 
TABLE 5. Percentage of Students in Each Country Group who Considered the Event Might Make Them Remain in the U.S.

Permanently

Events that might make them stay in the U.S.
HOME COUNTRIES

IRAN

$\mathrm{n}=122$

$\%$
NIGERIA
$n=188$
$\%$

OF

TAIWAN

$\mathrm{n}=139$

$\%$
STUDENTS*

VENEZUELA

$\mathrm{n}=78$

$\%$

Political conflict at home

Not able to find $a$ job at

44.3

14.8

home

A good job offer in U.S. 18.9 Marriage to U.S. citizen

Family member's advice

18.9

9.8

14.9

27.3

5.3

7.9

19.2

19.2

7.4

33.1

5.9

2.7

6.5

10.8

34.6

11.5

7.7

Nothing would make me 21.3 stay permanently in U.S.

66.5

16.5

25.6

* Percentage does not add up to 100 since students were allowed to choose more than one event.

Source: Lee, M. Y. and Ray, M C., 1987: 77. 
Table 6. Mean Scores of Likelihood to Remain in U.S., Anticipated Satisfaction at Home, and Perceived Racial Barrier in the U.S.

SIGNIFICANT DIFFERENCES IN
LOW $\quad \begin{aligned} & \text { MEANS } \\ & \text { HIGH }\end{aligned}$

Llikelihood to remain in U.S. permanently $\begin{array}{llll}N(1.8) 1 & V(2.7) & I(3.8) a & T(3.9) a\end{array}$

Anticipated satisfaction with:

$\begin{array}{lllll}\text { Finding a job approp- I(4.0)b } & T(4.2) b c & V(4.6) c & N(5.7)\end{array}$ riate to training Adequate salary Finding Appropriate housing

Having funds for research

Having facilities to use $\mathrm{I}(3.5) \quad \mathrm{T}(4.0) \mathrm{h} \quad \mathrm{V}(4.1) \mathrm{h} \quad \mathrm{N}(4.6)$

U.S. training

$\begin{array}{llll}\text { Having resources to use I(3.4) } & \mathrm{T}(3.9) \mathrm{i} & \mathrm{V}(4.3) \mathrm{i} & \mathrm{N}(4.8)\end{array}$

U.S. training

$\begin{array}{lllll}\text { Perceived racial } & V(1.8) j & I(2.1) j & T(2.7) & N(3.7)\end{array}$

barrier

$\begin{array}{llll}T(4.0) d & \mathrm{I}(4.1) \mathrm{d} & \mathrm{V}(4.6) \quad \mathrm{N}(5.2)\end{array}$

I(4.0)e $\quad V(4.3)$ ef $\quad T(4.6) f \quad N(5.4)$

$\begin{array}{lllll}\text { Perceived cultural } & V(1.8) & \mathrm{I}(2.9) \mathrm{k} & \mathrm{T}(2.9) \mathrm{k} & \mathrm{N}(3.3)\end{array}$ barrier

1. Within each row, the same alphabet indicates the means did not differ significantly and other means differed with $p<.05$. I=Iran, $T=$ Taiwan, $\mathrm{N}=$ Nigeria, $\mathrm{V}=$ Venezuela.

Source: Lee, M. Y. and Ray, M C., 1987: 77. 
APPENDIXD

\section{DESCRIPTION OF COMMUNITY COLLEGES}

TABLES A, B, C, D

FIGURE 3 
International* student Enrollment by world Region:

National Comparisons with

Miami-Dade Community College Opening Fall Term $1986-87$ and $1989-90$

\begin{tabular}{|c|c|c|c|c|c|c|}
\hline & \multicolumn{3}{|c|}{ Miami-Dade } & \multicolumn{3}{|c|}{ National } \\
\hline & $\begin{array}{l}\text { Number } \\
\text { From } \\
\text { Region }\end{array}$ & $\begin{array}{l}\text { Percent } \\
\text { of all } \\
\text { Interna- } \\
\text { tional } \\
\text { students }\end{array}$ & Rank & $\begin{array}{l}\text { Number } \\
\text { Erom } \\
\text { Region }\end{array}$ & $\begin{array}{l}\text { Percent } \\
\text { of all } \\
\text { Interna- } \\
\text { tional } \\
\text { students }\end{array}$ & Rank \\
\hline \multicolumn{7}{|c|}{$1986-87$} \\
\hline Latin America & 4,271 & 85.2 & 1 & 43,480 & 12.4 & 3 \\
\hline Middle East & 361 & 7.2 & 2 & 47,000 & 13.4 & 2 \\
\hline Europe & 161 & 3.2 & 3 & 36,140 & 10.3 & 4 \\
\hline Far East & 105 & 2.1 & 4 & 170,880 & 48.9 & 1 \\
\hline Africa & 84 & 1.7 & 5 & 31,580 & 9.1 & 5 \\
\hline North America & 26 & 0.5 & 6 & $16,300$. & 4.7 & 6 \\
\hline oceania & 2 & 0.1 & 7 & 4,230 & 1.2 & 7 \\
\hline \multirow[t]{2}{*}{ Total } & 5,010 & 100.0 & & 349,610 & 100.0 & \\
\hline & · & $1989-90$ & & . & & \\
\hline Latin America & 4,786 & 86.8 & 1 & 48,090 & 12.4 & 2 \\
\hline Europe & 246 & 4.5 & 2 & 46,040 & 11.9 & 3 \\
\hline Middle East & 232 & 4.2 & 3 & 37,330 & 9.6 & 4 \\
\hline Far East & 162 & 2.9 & 4 & 208,110 & 53.9 & 1 \\
\hline Africa & 58 & 1.0 & 5 & 24,570 & 6.4 & 5 \\
\hline Worth America & 33 & 0.5 & 6 & 18,590 & 4.8 & 6 \\
\hline oceania & 1 & 0.1 & 7 & 4,010 & 1.0 & 7 \\
\hline Missing* " & & & & 110 & & \\
\hline Total & 5,518 & 100.0 & & 386,850 & 100.0 & \\
\hline
\end{tabular}

- Includes Visa, Refugee and (in addition for M-DCC) Parolees/Asylees * Published data discrepancy.

Data Sources: Miami-Dade Community College, District Admission and Registration Services - ADSO7J00 Non-United States Citlzen student Enrollments - Fall Term 1986-87 and Fall Term 1990-9l.

National Data - Institute of International Education, open Doors 1986-87, P. Vi. open Doors 1989-90, D. V11.

Source: Baldwin, 1991: 25 


\section{TABLE B}

Comunity colleges with the Most Interrational students opening Fald resm 1989-90

\begin{tabular}{|c|c|c|c|c|}
\hline community colleges & Location & $\begin{array}{l}\text { Number } \\
\text { of } \\
\text { Interna- } \\
\text { tional } \\
\text { studenta }\end{array}$ & $\begin{array}{l}\text { Interna- } \\
\text { tional } \\
\text { enrolimene } \\
\text { of state }\end{array}$ & $\begin{array}{c}\text { Persent } \\
\text { of } \\
\text { state }\end{array}$ \\
\hline Mdand-oade communiey coliege & Fiordda & 5,518 & 8,529 & 64.7 \\
\hline Northern Virglnda commundty college & $V \perp 5 g i n 2 a$ & 1.562 & 1.720 & 90.8 \\
\hline santa Monzea college & caidforr.2a & 1.079 & 13.129 & 8.2 \\
\hline menegomery commundty college & Mazyiand & 1.063 & 2.370 & 44.9 \\
\hline CUNY-La Guardla community college & New YOsk & 864 & 3.052 & 28.3 \\
\hline Broward community college & Florada & $804^{*}$ & 8,529 & 9.4 \\
\hline $\begin{array}{l}\text { Cliy colleges of chicago- } \\
\text { Harcid washington (one eampus oniy) }\end{array}$ & $I: 2: n 0: 8$ & 768 & 1,600 & 48.0 \\
\hline Burker Hill community college & Massachusetss & 679. & 1,619 & 41.9 \\
\hline Plina community college & Ar: $20 \pi$ a & 670 & 1,246 & 53.8 \\
\hline $\begin{array}{l}\text { Los angeles cley college } \\
\text { (one ingus only) }\end{array}$ & Cab:fornda & 656 & 13.129 & 5.0 \\
\hline $\begin{array}{l}\text { Iscal rop ren Ineernational Enrodiments } \\
\text { Two-year colileges }\end{array}$ & $1 n$ & 13,663 & & \\
\hline 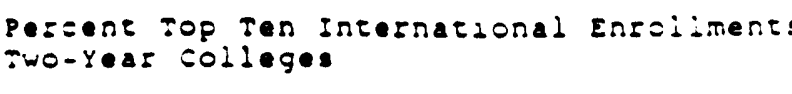 & es $:-\pi$ & 26.1 & & \\
\hline $\begin{array}{l}\text { Iscal Inzernational Enroliments in Ali or } \\
\text { iwo-year colleges }\end{array}$ & ornes & 38,779 & & \\
\hline $\begin{array}{l}\text { Perzer: Incernational Enzoliments ir Aij } \\
\text { Twc-Oear coileges }\end{array}$ & i other & 73.9 & & \\
\hline t:ad Inteznational Enrollments in twe ye & tear colieges & 52.442 & & \\
\hline
\end{tabular}

- $s s=: m a=e$

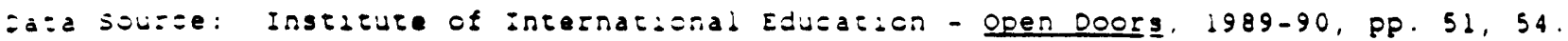
Scurce: Baldwin. $1991: 13$ 
Table $C$

Top Ten Program Declaracions of visa students

At Miami-Dade Commity College

Closing Fall ierm 1990.91

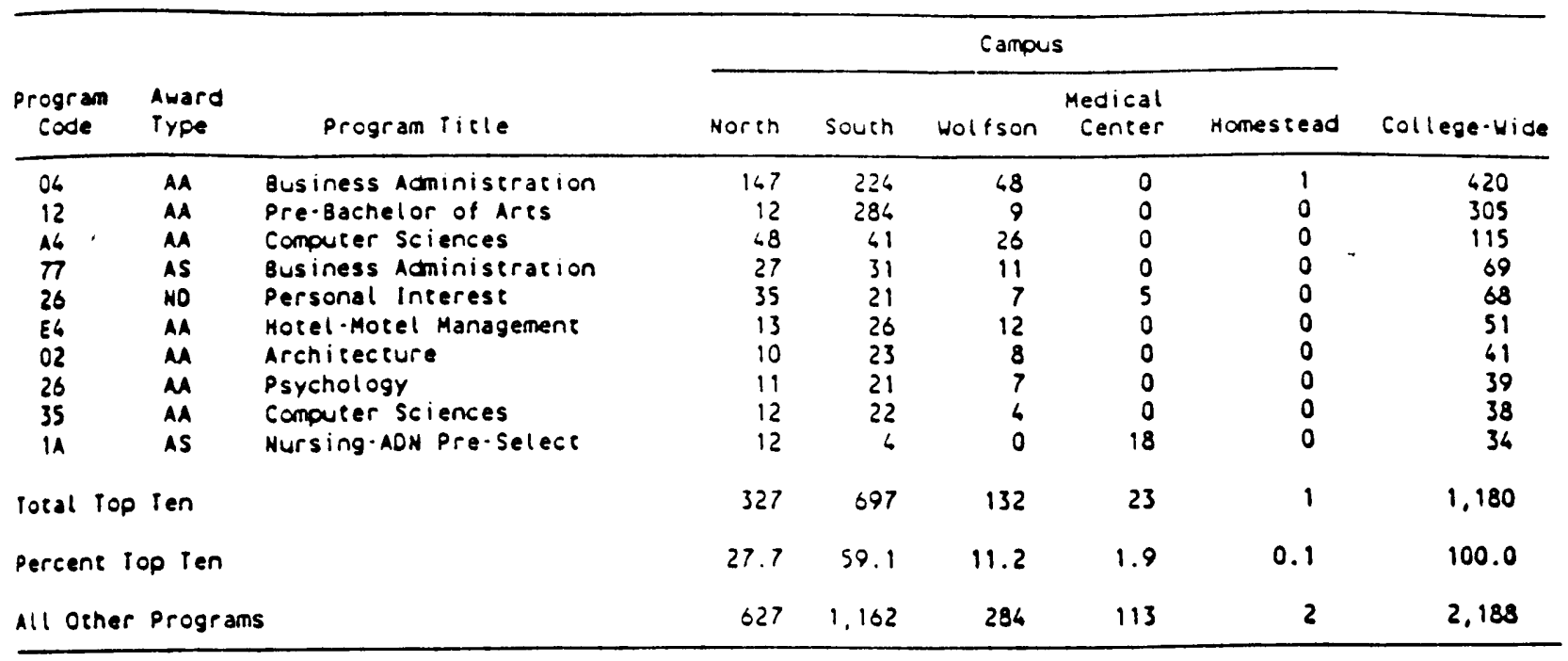

Oaca Source: IRS60 Closing fall Term 1990.91

Source: Baldwin, 1991: 62 
TABLE D

Ethnic Headcount by Campus

Miami-Dade Community College, Fall 1991

Ethnic

Category NORTH SOUTH WOLFSON MED

CTR

HOME-

COLLEGE-

STEAD WIDE

White non

Hispanic

2,593

6,025

2,057

1,086

1,203

12,964

Black non

Hispanic

5,673

1,669

1,574

1,427

322

10,665

Hispanic

6,859

13,530

8,379

1,410

470

30,648

(Asian/

Indian)

383

574

134

124

51

1,252

IOTAL

15.508

21.798

12.140

4.047

2.046

55.539

Source: Morris, 1992 
Figure 3

Educational Objectives of Students by

Citizenship

Miami-Dade Community College

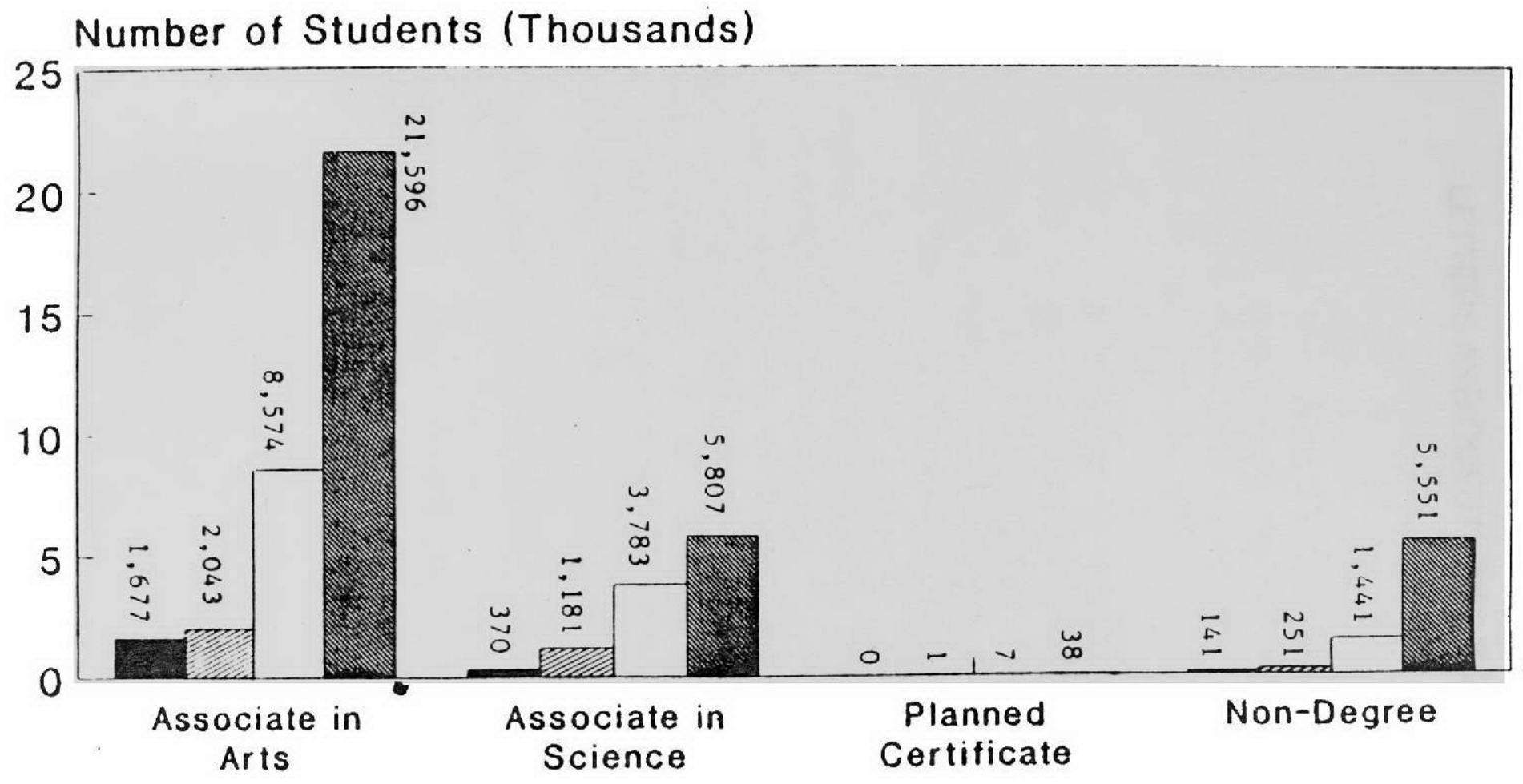

Citizenship

Visa W Refugee/Asylee

$\square$ Resident Alien U.S. Citizen 
APPENDIXE

LETTERS AND QUESTIONNAIRES

160 
February 25, 1992

\section{Dear}

I am preparing a doctoral dissertation for the Ed. D. in Community College Education from Florida International University. The title of the dissertation is "Relevance of the Community College Curriculum to the International Student."

In this study I am attempting to interview students from four different countries in order to determine the level of satisfaction international students have regarding program services and curriculum. I have selected your country because I believe the responses would contribute significantly to this research.

In this regard, I am requesting that you attend a meeting of "Miami-Dade Students from " where I shall give a presentation, lead a short discussion and hand out a questionnaire. Please be assured that all information is totally anonymous and kept in the strictest confidence. If you are interested in the results of this research, I will be most happy to forward the information to you. The meeting will be held at:

Scott Hall, Room 1122, 1:40 P.M., March 10

I will call to confirm your attendance. Realizing your time is valuable, I would greatly appreciate your help in this effort. Please call at (H) 6886180 or (W) 2371022 if there are any questions.

Sincerely,

Michael J. Baglino

Instructor, Social Sciences 


\section{Dear}

Approximately two months ago I mailed a letter to you requesting your attendance at a meeting of international students. The purpose of the meeting was to present information about issues concerning international students and ask you to complete a questionnaire. Another meeting is being scheduled and your attendance would be greatly appreciated.

I am preparing a doctoral dissertation for the Ed. D. in Community College Education from Florida International University. The title of the dissertation is "Relevance of the Community College Curriculum to the International Student."

In this study I am attempting to interview students from four different countries in order to determine the level of satisfaction international students have regarding program services and curriculum. I have selected your country because I believe the responses would contribute significantly to this research.

In this regard, I am requesting that you attend a meeting of "Miami-Dade Students from where I shall give a presentation, lead a short discussion and hand out a questionnaire. Please be assured that all information is totally anonymous and kept in the strictest confidence. If you are interested in the results of this research, I will be most happy to forward the information to you. The meeting will be held at:

\section{Scott Hall, Room 1122, 1:50 P.M., May 11}

I will call to confirm your attendance. Realizing your time is valuable, I would greatly appreciate your help in this effort. Please call at (H) 6886180 or (W) 2371022 if there are any questions.

Sincerely,

Michael J. Baglino

Instructor, Social Sciences 


\section{GROUP INTERVIEW AND OPEN DISCUSSION GUIDELINES}

1. What are your reasons for studying at a community college? (eg. social, patriotic, financial)

2. What are the objectives of your education? (eg. obtain a specialization or vocational skill, technical skills, practical experience in field, leadership skills, administrative skills, promote change in your country)

3. What type of work do you intend to do when you return home?

4. What might influence you to remain in the U.S. (eg. job, marriage, problems at home)

5. What courses in the curriculum have you found most or least relevant to your personal and career needs and interests? Why?

6. What courses in the curriculum have you found most or least relevant to your country's needs? Why?

7. What experiences in the curriculum do you find most relevant that can be applied to the needs of your country? (eg. seminar, technical skills, on the job training, learning solutions found in America's community)

8. How satisfied are you with college services? (eg. health, housing, advising, counseling, information on college and American life) 


\section{INTERNATIONAL STUDENT QUESTIONNAIRE \\ OPEN ENDED QUESTIONNAIRE \\ PERSONAL INFORMATION}

1. Country of origin:

2. Sex:

1. male

2. female

3. What is your major program of study?

4. What is the minimal degree you expect to receive while studying in the United States?
1. A. S. or A. A.
2. B. A. or B. S.
3. M. A. or M. S.
4. doctorate

5. Do you believe that there will be a job available to you upon return to your home country?

1. yes

2. no

3. maybe

6. What might make you stay permanently in the U.S.? (eg. political conflict at home, not finding a job, job offer in U. S., marriage, family advice, other) 
7. With which personal services provided by the college are you satisfied or dissatisfied? (eg. health, housing, counseling, academic advising, information on college and American life)

8. Which courses in the curriculum have you found most or least relevant to your personal and career needs and interests? Why?

9. What experiences in the curriculum do you find most relevant that can be applied to the needs of your country? (eg. work experience, research, introducing information about your country to your professor, technical skills learned, seminars on international topics)

10. COMMENTS: 


\section{INTERNATIONAL STUDENT SURVEY \\ PERSONAL INFORMATION}

1. Country of origin:

2. You are:

1. single

2. married

3. separated

4. divorced

5. widowed

3. Your age: 1. 18-25

2. $26-35$

3. $36-45$

4. $46+$

4. Sex:

1. male

2. female

5. What is your major or program of study?

6. What degree are you seeking at MDCC?

1. A. A.

2. A. S.

3. Planned Certificate

4. Non Degree

7. Do you believe that there will be a job available to you upon your return to your home country?
1. yes
2. no
3. maybe

8. Is it possible that you might remain permanently in the United States?

1. yes

2. no

3. maybe

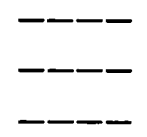




\section{SATISFACTION WITH COLLEGE SERVICES}

$\begin{array}{ccccccc}\text { very } & \text { quite } & & & & \text { quite } & \text { very } \\ \text { satisfied } & \text { satisfied } & \text { satisfied } & \text { undecided } & \text { unsatisfied } & \text { unsatisfied } & \text { unsatisfied } \\ (1) & (2) & (3) & (4) & (5) & (6) & (7)\end{array}$

9. During your enrollment at this community college, how do you rate the programs offered for foreign students?

A. The college offer of adequate information to aid in adjustment to life in the United States.

B. Community and health services information available to foreign students and their families.

C. The opportunity to assess academic and personal career needs with counselors and advisors.

D. Availability of information and procedures in planning the college program.

E. Faculty members spending time for association or guidance.

F. Receiving credit for academic work done outside the U. S.

\section{CURRICULUM RELEVANCE}

10. During your enrollment at this community college how do you rate the curriculum in terms of being relevant and applicable to your goals?

G. The college curriculum relevant to your future job in your country.

H. Opportunities to give information about your country in classes. 


$\begin{array}{ccccccc}\text { very } & \text { quite } & & & & \text { quite } & \text { very } \\ \text { satisfied } & \text { satisfied } & \text { satisfied } & \text { undecided } & \text { unsatisfied } & \text { unsatisfied } & \text { unsatisfied } \\ (1) & (2) & (3) & (4) & (5) & (6) & (7)\end{array}$

\section{_ I. A curriculum that included international materials in courses.}

J. The availability of seminars dealing with problems of national development.

K. The college curriculum relevant to the needs of your country.

L. The level of technology applicable to the future of your country.

M. The curriculum inclusion of training to introduce changes in your country.

N. The curriculum inclusion of training for a leadership role in your country.

0 . The exchange of visiting professors between universities of your country and those at this college.

P. Opportunity for practical or work experience in your field before returning home. 


\section{APPENDIX F}

SUMMARY OF RESULTS

TABLES 33-36 
TABLE 33. SUMMARY OF RESULTS: MEANS OF THE PERCEPTION OF SATISFACTION OF COLEGE SERVICES TO THE INTERNATIONAL STUDENT BY COUNTRY

ITEM

BAH COLOM HAITI PAKI TOTAL

1. COLIEGEOFFER OF ADEQUATE SERVICES TO AID IN ADJUSTMENT TO LIFE IN U.S.

2. COMMUNITY AND HEALTH SERVICES

AVAILABLE TO FOREIGN STUDENTS

AND FAMILIES

3. OPPORTUNITY TO ASSESS ACADEMIC

AND PERSONAL CAREER NEEDS WITH

COUNSELORS AND ADVISORS

- 4. AVAILABILITY OF INFORMATION AND

$\checkmark \quad$ PROCEDURES IN PLANNING THE

COUEGEPROGRAM

5. FACULTY MEMBERS SPENDING TIME FOR ASSOCIATION AND GUIDANCE

6. RECEIVING CREDIT FOR ACADEMIC WORK DONE OUTSIDE THE U.S.

$\begin{array}{rccccc}\text { MEAN } & 3.87 & 4 & 3.833 & 4.5 & 4.014 \\ \text { ST.DEV. } & 1.217 & 0.816 & 1.791 & 1.286 & 1.325 \\ & & & & & \\ \text { MEAN } & 4.913 & 4.688 & 4.833 & 4.786 & 4.817 \\ \text { ST.DEV. } & 1.379 & 1.104 & 1.823 & 1.051 & 1.356 \\ & & & & & \\ \text { MEAN } & 3.696 & 3.312 & 3.056 & 4.929 & 3.69 \\ \text { ST.DEV. } & 1.717 & 0.873 & 1.056 & 1.207 & 1.44 \\ & & & & & \\ \text { MEAN } & 3.696 & 3 & 3.056 & 4.429 & 3.521 \\ \text { ST.DEV. } & 1.46 & 0.894 & 1.211 & 1.222 & 1.329 \\ & & & & & \\ \text { MEAN } & 3.87 & 3.562 & 3.611 & 3.643 & 3.69 \\ \text { ST.DEV. } & 1.359 & 0.814 & 1.539 & 1.277 & 1.272 \\ & & & & & \\ \text { MEAN } & 4.696 & 4.375 & 4.222 & 4.714 & 4.507 \\ \text { ST.DEV. } & 0.926 & 0.957 & 1.06 & 0.726 & 0.939\end{array}$

MEAN OF THE SERIES OF QUESTIONS

MEAN

$\begin{array}{llll}4.123 & 3.823 & 3.769\end{array}$

4.5

ST.DEV.

0.878

$\begin{array}{llll}0.569 & 1.085 & 0.592\end{array}$

0.858 
TABLE 34. SUMMARY OF RESULTS: MEANS OF THE PERCEPTION OF SATISFACTION OF COLLEGE SERVICES TO THE INTERNATIONALSTUDENT BY MAJOR

\begin{tabular}{|c|c|c|c|c|c|}
\hline \multicolumn{2}{|l|}{ ITEM } & \multirow{2}{*}{$\begin{array}{c}\text { BUSINESS } \\
4.12\end{array}$} & \multicolumn{2}{|c|}{ TECHNOLOGY PRE-UNIVERSITY } & \multirow{2}{*}{$\begin{array}{l}\text { TOTAL } \\
4.014\end{array}$} \\
\hline 1. COLEGE OFFER OF ADEQUATE & MEAN & & 4.182 & 3.75 & \\
\hline $\begin{array}{l}\text { SERVICES TO AID IN ADJUSTMENT } \\
\text { TO LIFE IN U.S. }\end{array}$ & S.D. & 1.269 & 1.593 & 1.113 & 1.325 \\
\hline 2. COMMUNITY AND HEALTH SERVICES & MEAN & 5 & 4.545 & 4.875 & 4.817 \\
\hline $\begin{array}{l}\text { AVAILABLE TO FOREIGN STUDENTS } \\
\text { AND FAMILIES }\end{array}$ & S.D. & 1.08 & 1.625 & 1.361 & 1.356 \\
\hline 3. OPPORTUNITY TO ASSESS ACADEMIC & MEAN & 3.88 & 3.273 & 3.875 & 3.69 \\
\hline $\begin{array}{l}\text { AND PERSONAL CAREER NEEDS WITH } \\
\text { COUNSELORS AND ADVSORS }\end{array}$ & S.D. & 1.394 & 1.453 & 1.454 & 1.44 \\
\hline 4. AVAILABILITY OF INFORMATION AND & MEAN & 3.64 & 3.182 & 3.708 & 3.521 \\
\hline $\begin{array}{l}\text { PROCEDURES IN PLANNING THE } \\
\text { COUEGEPROGRAM }\end{array}$ & S. D. & 1.381 & 1.332 & 1.268 & 1.329 \\
\hline 5. FACULTY MEMBERS SPENDING TIME & MEAN & 3.92 & 3.682 & 3.458 & 3.69 \\
\hline FOR ASSOCIATION AND GUIDANCE & S.D. & 1.152 & 1.492 & 1.179 & 1.272 \\
\hline $\begin{array}{l}\text { 6. RECEIVING CREDIT FOR ACADEMIC } \\
\text { WORK DONE OUTSIDE THE U.S. }\end{array}$ & $\begin{array}{l}\text { MEAN } \\
\text { S.D. }\end{array}$ & $\begin{array}{c}4.6 \\
0.866\end{array}$ & $\begin{array}{c}4.5 \\
1.102\end{array}$ & $\begin{array}{l}4.417 \\
0.881\end{array}$ & $\begin{array}{l}4.507 \\
0.939\end{array}$ \\
\hline $\begin{array}{l}\text { MEAN OF THE SERIES OF QUESTIONS } \\
\text { S. D. }\end{array}$ & $\begin{array}{l}\text { MEAN } \\
0.739\end{array}$ & $\begin{array}{l}4.193 \\
0.999\end{array}$ & $\begin{array}{l}3.894 \\
0.845\end{array}$ & $\begin{array}{l}4.014 \\
0.858\end{array}$ & 4.04 \\
\hline
\end{tabular}


TABLE 35A. SUMMARY OF RESULTS: MEANS OF THE PERCEPTION OF SATISFACTION OF RELEVA OF THE COLLEGE CURRICULUM TO THE INTERNATIONAL STUDENT BY COUNTRY

ITEM

BAHA COLOM HAITI PAKI TOTAL

1. COLLEGE CURRICULUM RELEVANT TO YOUR FUTURE JOB IN YOUR COUNTRY

MEAN 2.652

$2.562 \quad 2.833$

3.071

2.761

ST. DEV. 1.112

$0.964 \quad 1.339$

$0.917 \quad 1.101$

2. OPPORTUNITIES TO GIVE INFORMATION

MEAN 3.739

3.562

3.667

4.143

3.761

$\sim \quad$ ABOUT YOUR COUNTRY IN CLASSES

ST. DEV. 1.389

1.153

1.414

1.167

1.292

3. CURRICULUM THAT INCLUDED

INTERNATIONAL MATERIALS

MEAN 4.565

3.688

3.833

4.857

4.239

ST. DEV. 1.343

$\begin{array}{llll}0.873 & 1.383 & 0.949 & 1.259\end{array}$

IN COURSES

4. AVAILABILITY OF SEMINARS

MEAN 4.391

4.125

4.167

4.929

4.381

DEALING WITH PROBLEMS OF

ST. DEV. 1.196

1.204

1.505

1.385

1.324

NATIONAL DEVELOPMENT

5. COLLEGE CURRICULUM RELEVANT

TONEEDS OF YOUR COUNTRY

$\begin{array}{cc}\text { MEAN } & 2.913 \\ \text { ST. DEV. } & 1.125\end{array}$

3.375

3.556

4.286

3.451

$\begin{array}{llll}0.806 & 1.294 & 1.267 & 1.216\end{array}$ 
TABLE 35B. SUMMARY OF RESULTS: MEANS OF THE PERCEPTION OF SATISFACTION OF RELEVAT OF THE COLLEGE CURRICULUM TO THE INTERNATIONAL STUDENT BY COUNTRY

ITEM

BAHA COLOM HAITI PAKI TOTAL

6. LEVEL OF TECHNOLOGY APPLICABLE TO THE FUTURE OF YOUR COUNTRY

$\begin{array}{cccccc}\text { MEAN } & 2.696 & 2.75 & 2.778 & 3 & 2.789 \\ \text { ST. DEV. } & 0.876 & 0.683 & 1.166 & 1.109 & 0.955 \\ & & & & & \\ \text { MEAN } & 3.261 & 3.438 & 3.111 & 3.143 & 3.239 \\ \text { ST. DEV. } & 1.054 & 0.814 & 1.491 & 1.099 & 1.127\end{array}$

7. CURRICULUM INCLUDING TRAINING

TO INTRODUCE CHANGES IN YOUR COUNTRY

8. CURRICULUM INCLUDING TRAINING FOR A LEADERSHIP ROLE INYOUR COUNTRY

9. EXCHANGE OF VISITING PROFESSORS BETWEEN UNIVERSITIES OF YOUR COUNTRY AND THIS COLLEGE 10. OPPORTUNITY FOR PRACTICAL EXPERIENCE IN YOUR FIELD BEFORE RETURNING HOME

$\begin{array}{cccccc}\text { MEAN } & 3.174 & 3.375 & 3.222 & 3 & 3.197 \\ \text { ST. DEV. } & 1.193 & 0.806 & 1.353 & 1.109 & 1.129 \\ & & & & & \\ \text { MEAN } & 4.652 & 4.188 & 4.389 & 5.429 & 4.634 \\ \text { ST. DEV. } & 1.265 & 0.655 & 1.378 & 1.089 & 1.21 \\ & & & & & \\ \text { MEAN } & 3.957 & 4.312 & 3.111 & 3.857 & 3.803 \\ \text { ST. DEV. } & 1.492 & 1.448 & 1.53 & 1.512 & 1.527\end{array}$

MEAN OF THE SERIES OF QUESTIONS

$\begin{array}{cccccc}\text { MEAN } & 3.6 & 3.537 & 3.467 & 3.971 & 3.625 \\ \text { ST. DEV. } & 0.705 & 0.504 & 0.994 & 0.533 & 0.732\end{array}$


TABLE 36A. SUMMARY OF RESULTS : MEANS OF THE PERCEPTION OF SATISFACTION OF RELEVANCE OF THE COLLEGE CURRICULUM TO THE INTERNATIONAL STUDENT BY MAJOR

\begin{tabular}{lll}
\hline ITEM & BUS. TECH. PRE-UNIV. TOTAL
\end{tabular}

1. COLLEGE CURRICULUM RELEVANT TO YOUR FUTURE JOB IN YOUR COUNTRY

$\begin{array}{ccccc}\text { MEAN } & 2.68 & 3 & 2.625 & 2.761 \\ \text { ST. DEV. } & 0.945 & 1.272 & 1.096 & 1.101 \\ & & & & \\ \text { MEAN } & 3.8 & 3.682 & 3.792 & 3.761 \\ \text { ST. DEV. } & 1.472 & 1.323 & 1.103 & 1.292 \\ & & & & \\ \text { MEAN } & 4.2 & 4.364 & 4.167 & 4.239 \\ \text { ST. DEV. } & 1.19 & 1.364 & 1.274 & 1.259 \\ & & & & \\ \text { MEAN } & 4.48 & 4.182 & 4.485 & 4.381 \\ \text { ST. DEV. } & 1.295 & 1.593 & 1.103 & 1.324 \\ \text { MEAN } & 3.44 & 3.591 & 3.333 & 3.451 \\ \text { ST. DEV. } & 1.158 & 1.403 & 1.129 & 1.216\end{array}$

2. OPPORTUNITIES TO GIVE INFORMATION ABOUT YOUR COUNTRY IN CLASSES

$\pm$

3. CURRICULUM THAT INCLUDED INTERNATIONAL MATERIALS IN COURSES

4. AVAILABILITY OF SEMINARS DEALING WITH PROBLEMS OF NATIONAL DEVELOPMENT 5. COLLEGE CURRICULUM RELEVANT TO NEEDS OF YOUR COUNTRY 
TABLE 36B. SUMMARY OF RESULTS : MEANS OF THE PERCEPTION OF SATISFACTION OF RELEVANCE OF THE COLLEGE CURRICULUM TO THE INTERNATIONAL STUDENT BY MANOR

\begin{tabular}{lll}
\hline ITEM & BUS. TECH. PRE-UNIV.TOTAL
\end{tabular}

6. LEVEL OF TECHNOLOGY APPLICABLE TOTHE FUTURE OF YOUR COUNTRY

$\begin{array}{ccccc}\text { MEAN } & 2.68 & 2.91 & 2.79 & 2.789 \\ \text { ST. DEV. } & 0.852 & 1.109 & 0.932 & 0.955\end{array}$

7. CURRICULUM INCLUDING TRAINING

$\begin{array}{ccccc}\text { MEAN } & 3.08 & 3.5 & 3.167 & 3.239 \\ \text { ST. DEV. } & 0.997 & 1.336 & 1.049 & 1.127\end{array}$

YOURCOUNTRY
8. CURRICULUM INCLUDING TRAINING

FOR A LEADERSHIP ROLE

INYOUR COUNTRY

9. EXCHANGE OF VISITING PROFESSORS

BETWEEN UNIVERSITIES OF YOUR

COUNTRY AND THIS COLLEGE

10. OPPORTUNITY FOR PRACTICAL

EXPERIENCE IN YOUR FIELD

$\begin{array}{lllll}\text { MEAN } & 2.96 & 3.545 & 3.125 & 3.197\end{array}$

$\begin{array}{lllll}\text { ST. DEV. } & 0.935 & 1.224 & 1.191 & 1.129\end{array}$

BEFORE RETURNING HOME

$\begin{array}{ccccc}\text { MEAN } & 4.84 & 4.591 & 4.458 & 4.634 \\ \text { ST. DEV. } & 1.214 & 1.469 & 0.932 & 1.21 \\ & & & & \\ \text { MEAN } & 3.76 & 3.727 & 3.917 & 3.803 \\ \text { ST. DEV. } & 1.393 & 1.778 & 1.472 & 1.527\end{array}$

MEAN OF THE SERIES OF QUESTIONS

$\begin{array}{ccccc}\text { MEAN } & 3.592 & 3.709 & 3.583 & 3.625 \\ \text { ST. DEV. } & 0.593 & 0.884 & 0.734 & 0.732\end{array}$


APPENDIX G

RELIABILITY SCORES

TABLE E 
TABLE E. RELIABILITY SCORES*

\begin{tabular}{lcc}
\hline & $\begin{array}{c}\text { NUMBER OF } \\
\text { ITEMS IN } \\
\text { COMPOSITE }\end{array}$ & RELIABILITY \\
\hline NEEDS FOR FOREIGN STUDENT LFE INFORMATION & 3 & .64 \\
SATISFACTION OF THE ABOVE & 3 & .64 \\
NEEDS REGARDING ACADEMIC PLANNING & 3 & .70 \\
SATISFACTION OF THE ABOVE & 3 & .47 \\
NEEDS REGARDING ACADEMIC RELATIONSHIPS & 4 & .79 \\
SATISFACTION OF THE ABOVE & 4 & .71 \\
NEEDS FOR RELEVANCY IN EDUCATION & 7 & .84 \\
SATISFACTION OF THE ABOVE & 7 & .81 \\
NEEDS FOR TRAINING TO APPLY KNOWLEDGE & 3 & .71 \\
SATISFACTION OF THE ABOVE & 3 & .69 \\
NEEDS FOR PRACTICAL EXPERIENCE & 2 & .84 \\
SATISFACTION OF THE ABOVE & 2 & .84 \\
NEEDS REGARDING UNIVERSITY INFORMATION & 7 & .83 \\
SATISFACTION OF THE ABOVE & 7 & .85 \\
NEEDS REGARDING RELATIONSHIP WITH FACULTY/STAFF & 5 & .86 \\
SATISFACTION OF THE ABOVE & 5 & .84 \\
& & \\
\hline
\end{tabular}

"RELIABILITY SCORES ARE CRONBACH'S ALPHA VALUES (LEE, 1981: 46) 